\title{
A global overview of drought and heat-induced tree mortality reveals emerging climate change risks for forests
}

Craig D. Allen a, ${ }^{*}$, Alison K. Macalady b, Haroun Chenchouni c, Dominique Bachelet d, Nate McDowell e, Michel Vennetier f, Thomas Kitzberger g, Andreas Rigling h, David D. Breshears i, E.H. (Ted) Hogg j, Patrick Gonzalez k, Rod Fensham 1, Zhen Zhangm, Jorge Castro n, Natalia Demidova o, Jong-Hwan Lim p, Gillian Allard q, Steven W. Running r, Akkin Semerci s, Neil Cobb t

a U.S. Geological Survey, Fort Collins Science Center, Jemez Mountains Field Station, Los Alamos, NM 87544, USA

b School of Geography and Development and Laboratory of Tree-Ring Research, University of Arizona, Tucson, AZ 85721, USA

c Department of Biology, University of Batna, 05000 Batna, Algeria

d Department of Biological and Ecological Engineering, Oregon State University, Corvalllis, OR 97330, USA

e Earth and Environmental Sciences, MS J495, Los Alamos National Laboratory, Los Alamos, NM 87544,USA

f CEMAGREF, ECCOREV FR 3098, Aix-Marseille University, Aix-en-Provence, France

g Laboratorio Ecotono, INIBIOMA-CONICET and Univ. Nacional del Comahue, Quintral 1250, 8400 Bariloche, Argentina

h Swiss Federal Institute for Forest, Snow and Landscape Research WSL, Zurcherstr. 111, CH-8903 Birmensdorf, Switzerland

i School of Natural Resources and Department of Ecology and Evolutionary Biology, University of Arizona, Tucson, AZ 85721, USA

j Northern Forestry Centre, Canadian Forest Service, 5320-122 Street, Edmonton, Alberta T6H 3S5, Canada

k Center for Forestry, University of California, Berkeley, CA 94720, USA

1 Queensland Herbarium, Environmental Protection Agency, Mt Coot-tha Road, Toowong, Queensland 4066, Australia

mResearch Institute of Forest Ecology, Environment and Protection, Chinese Academy of Forestry,

Key Laboratory of Forest Protection of State Forestry Administration, Beijing 100091, China

n Grupo de Ecologi'a Terrestre, Departamento de Ecologi'a, Universidad de Granada, Granada E-18071, Spain

o Northern Research Institute of Forestry, Nikitov St., 13, Arkhangelsk 163062, Russian Federation

p Division of Forest Ecology, Department of Forest Conservation, Korea Forest Research Institute \#57, Hoegi-ro, Dongdaemun-gu, Seoul 130-712,

Republic of Korea

q Forestry Department, Food and Agriculture Organization (FAO), Viale delle Terme di Caracalla, 00100 Rome, Italy

r Numerical Terradynamics Simulation Group, University of Montana, Missoula, MT 59812, USA

s Central Anatolia Forestry Research Institute, P.K. 24, 06501 Bahcelievler-Ankara, Turkey

t Department of Biological Sciences and Merriam Powell Center for Environmental Research, Northern Arizona University, Flagstaff, AZ 86011, USA

* Corresponding author. Tel.: +1 505672 3861x541; fax: +1 5056729607.

E-mail address: craig_allen@usgs.gov (C.D. Allen)

Published by Elsevier B.V.

\begin{abstract}
Greenhouse gas emissions have significantly altered global climate, and will continue to do so in the future. Increases in the frequency, duration, and/or severity of drought and heat stress associated with climate change could fundamentally alter the composition, structure, and biogeography of forests in many regions. Of particular concern are potential increases in tree mortality associated with climate-induced physiological stress and interactions with other climate-mediated processes such as insect outbreaks and wildfire. Despite this risk, existing projections of tree mortality are based on models that lack functionally realistic mortality mechanisms, and there has been no attempt to track observations of climatedriven tree mortality globally. Here we present the first global assessment of recent tree mortality attributed to drought and heat stress.
\end{abstract}

\section{Introduction}

Forested ecosystems are being rapidly and directly transformed by the land uses of our expanding human populations and economies. Currently less evident are the impacts of ongoing climate change on the world's forests. Increasing emissions of greenhouse gases are now widely acknowledged by the scientific community
Although episodic mortality occurs in the absence of climate change, studies compiled here suggest that at least some of the world's forested ecosystems already may be responding to climate change and raise concern that forests may become increasingly vulnerable to higher background tree mortality rates and die-off in response to future warming and drought, even in environments that are not normally considered waterlimited. This further suggests risks to ecosystem services, including the loss of sequestered forest carbon and associated atmospheric feedbacks. Our review also identifies key information gaps and scientific uncertainties that currently hinder our ability to predict tree mortality in response to climate change and emphasizes the need for a globally coordinated observation system. Overall, our review reveals the potential for amplified tree mortality due to drought and heat in forests worldwide.

as a major cause of recent increases in global mean temperature (about $0.58 \mathrm{C}$ since 1970) and changes in the world's hydrological cycle (IPCC, 2007a), including a widening of the Earth's tropical belt (Seidel et al., 2008; Lu et al., 2009). Even under conservative scenarios, future climate changes are likely to include further increases in mean temperature (about 2-4 8C globally) with significant drying in some regions 
(Christensen et al., 2007; Seager et al., 2007), as well as increases in frequency and severity of extreme droughts, hot extremes, and heat waves (IPCC, 2007a; Sterl et al., 2008).

Understanding and predicting the consequences of these climatic changes on ecosystems is emerging as one of the grand challenges for global change scientists, and forecasting the impacts on forests is of particular importance (Boisvenue and Running, 2006; Bonan, 2008). Forests, here broadly defined to include woodlands and savannas, cover $30 \%$ of the world's land surface (FAO, 2006). Around the globe societies rely on forests for essential services such as timber and watershed protection, and less tangible but equally important recreational, aesthetic, and spiritual benefits. The effects of climate change on forests include both positive (e.g. increases in forest vigor and growth from $\mathrm{CO} 2$ fertilization, increased water use efficiency, and longer growing seasons) and negative effects (e.g. reduced growth and increases in stress and mortality due to the combined impacts of climate change and climate-driven changes in the dynamics of forest insects and pathogens) (Ayres and Lombardero, 2000; Bachelet et al., 2003; Lucht et al., 2006; Scholze et al., 2006; Lloyd and Bunn, 2007). Furthermore, forests are subject to many other human influences such as increased ground-level ozone and deposition (Fowler et al., 1999; Karnosky et al., 2005; Ollinger et al., 2008). Considerable uncertainty remains in modeling how these and other relevant processes will affect the risk of future tree die-off events, referred to hereafter as 'forest mortality', under a changing climate (Loehle and LeBlanc, 1996; Hanson and Weltzin, 2000; Bugmann et al., 2001). Although a range of responses can and should be expected, recent cases of increased tree mortality and die-offs triggered by drought and/or high temperatures raise the possibility that amplified forest mortality may already be occurring in some locations in response to global climate change. Examples of

recent die-offs are particularly well documented for southern parts of Europe (Penũelas et al., 2001; Breda et al., 2006; Bigler et al., 2006) and for temperate and boreal forests of western North America, where background mortality rates have increased rapidly in recent decades (van Mantgem et al., 2009) and widespread death of many tree species in multiple forest types has affected well over 10 million ha since 1997 (Raffa et al., 2008). The common implicated causal factor in these examples is elevated temperatures and/or water stress, raising the possibility that the world's forests are increasingly responding to ongoing warming and drying.

This paper provides an overview of recent tree mortality due to climatic water stress and warm temperatures in forests around the globe. We identify 88 well-documented episodes of increased mortality due to drought and heat and summarize recent literature on forest mortality and decline. From this review we examine the possibility of emerging mortality risks due to increasing temperatures and drought. Climate as a driver of tree mortality is also reviewed, summarizing our scientific understanding of mortality processes as context for assessing possible relationships between changing climate and forest conditions. Note that while climatic events can damage forests in many ways ranging from ice storms to tornadoes and hurricanes, our emphasis is on climate-induced physiological stress driven by drought and warm temperatures. The ecological effects of increased mortality in forests and the associated consequences for human society remain largely unassessed. We conclude by outlining key information gaps and scientific uncertainties that currently limit our ability to determine trends in forest mortality and predict future climate-induced forest dieoff. Addressing these gaps would provide improved information to support policy decisions and forest management worldwide.

\section{Methods}

This paper emerged in part from collaborations and presentations developed in special sessions on climaterelated forest mortality at two international meetings: the 2007 annual meeting of the Ecological Society of America in San Jose, California (Allen and Breshears, 2007), and the 2008 international conference entitled "Conference on Adaptation of Forests and Forest Management to Changing Climate with Emphasis on Forest Health", in Umea ${ }^{\circ}$, Sweden (Allen, 2009). In addition to citing contributions from these sessions, we conducted a systematic search for published accounts of climate-induced tree mortality since 1970 using the ISI Web of Science and Google Scholar. We used different combinations of the key words "tree," "'forest," “mortality," “dieoff," '“dieback,", "decline," and "drought" in the searches. We also consulted regional forestry experts to find examples recorded in government documents and other sources outside the scientific literature.

From the extensive set of documents uncovered during these searches, we used two specific criteria to determine whether the reference was appropriate for this review. Criteria for inclusion were that the study included: (1) an estimate of area affected or amount of adult tree mortality at the stand or population level, based on ground measurements, aerial photography, or remote sensing, and (2) documentation of a strong correspondence between increases in mortality and increased water stress or high temperatures. We included examples where biotic agents were involved in the mortality, but excluded examples of fire-driven death. Studies of forest decline or partial canopy dieback without significant increases in mortality were also excluded, as were studies that documented only seedling mortality. To simplify presentation, we standardized study descriptors and combined references that describe impacts of the same event on the same tree species but used slightly different methods or were conducted at different spatial scales. To estimate trends in the literature related to climateinduced forest mortality, we searched the ISI Web of 
Science using the topic words "forest AND mortality AND drought" over the available interval from 1985 to 2009. We then controlled for increases in the general scientific literature related to forests by standardizing the number of target articles by the number of citations uncovered by a search using only the topic word "'forest.",

For each mortality event (listed as rows in Appendix Tables A1- A6) we tested the association between the forest type affected by mortality and the categorized duration of the mortality-triggering drought (seasonal event vs. multi-year drought) with a Chi-square analysis, comparing number of observed triggering droughts (by drought and forest type) versus expected number of triggering droughts. Forest types were grouped into four major biome types considering similar water limitations: (1) savannas, (2) conifer forests and Mediterranean woodlands, (3) temperate evergreen and deciduous forests, and (4) evergreen broadleaved tropical forests.

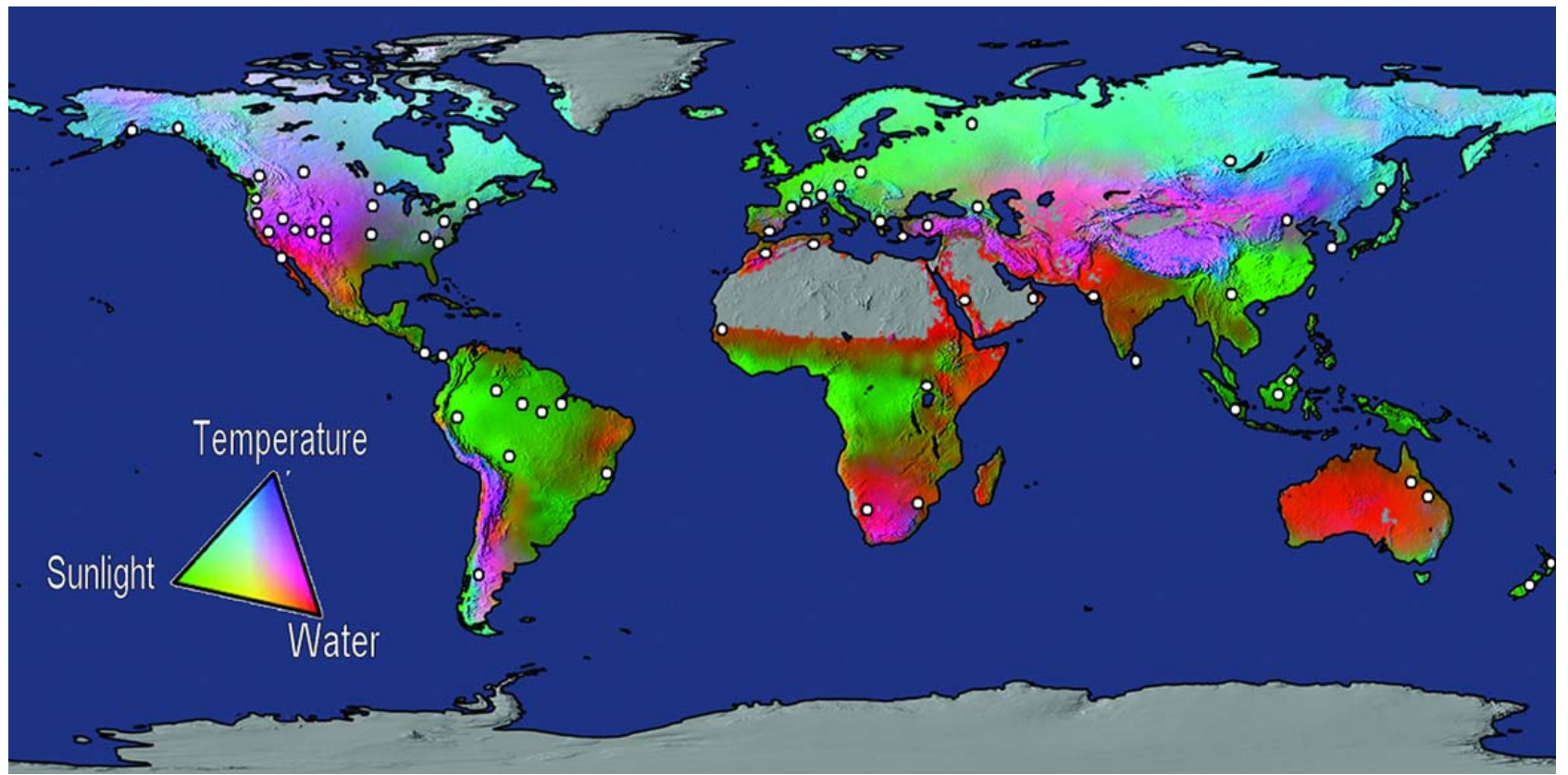

Fig. 1. White dots indicate documented localities with forest mortality related to climatic stress from drought and high temperatures. Background map shows potential environmental limits to vegetation net primary production (Boisvenue and Running, 2006). Only the general areas documented in the tables are shown-many additional localities are mapped more precisely on the continental-scale maps. Drought and heat-driven forest mortality often is documented in relatively dry regions (red/orange/ pink), but also occurs outside these regions.

\section{Results}

\subsection{Examples of recent climate-induced forest mortality}

More than 150 references that document 88 examples of forest mortality met our criteria of events that were driven by climatic water/heat stress since 1970 . The examples range from modest but significant local increases in background tree mortality rates to climatedriven episodes of regional-scale forest die-off. We found examples from each of the wooded continents that collectively span diverse forest types and climatic zones (Figs. 1-8 and Tables A1-A6). Despite our collective efforts to secure references from non-English language sources, this review is clearly more comprehensive for North America, Europe, and Australia, and obviously incomplete particularly for some regions, including mainland Asia and Russia.

Our searches also reveal that published reports of climate related forest mortality in the scientific literature have increased markedly in recent decades. For example, a search of the ISI Web of Science (23 July 2009) using the topic words "forest AND mortality AND drought" showed 546 references for the period 1985 through 2009, with a steep increase in articles published since 2003 (Fig. 9), even when standardized for general increases in the forest-related scientific literature. The years of elevated mortality documented in the references that met our criteria also show a clear increase in mortality events with a jump in 1998 and marked accumulation of events in the 2000s, particularly the years 2003-2004. Although these trends could be coincidental or a reflection of greater scientific interest in the topic of tree mortality, recent increases in reported events also mirror warming global temperatures. 


\subsubsection{Continental-scale summaries}

3.1.1.1. Africa. Increased tree mortality linked to drought and heat in Africa (Fig. 2; Table A1) includes examples from tropical moist forest in Uganda (Lwanga, 2003), mountain acacia (Brachystegia glaucescens) in Zimbabwe (Tafangenyasha, 2001), mesic savanna trees in South Africa's Kruger National Park (Viljoen, 1995), and centuries-old Aloe dichotoma in Namibia (Foden et al., 2007). In the Sahel, long-term decreases in precipitation linked to anthropogenic climate change (Biasutti and Giannini, 2006) have caused a die-off of mesic tree species in parts of Senegal (Gonzalez, 2001), especially following the severe drought of 1968-1973 (Poupon, 1980). Recent extreme drought in North Africa (Touchan et al., 2008) is linked to severe mortality of Atlas cedar (Cedrus atlantica) from Morocco to Algeria (El Abidine, 2003; Bentouati, 2008; Box 1, see also Fig. 3).

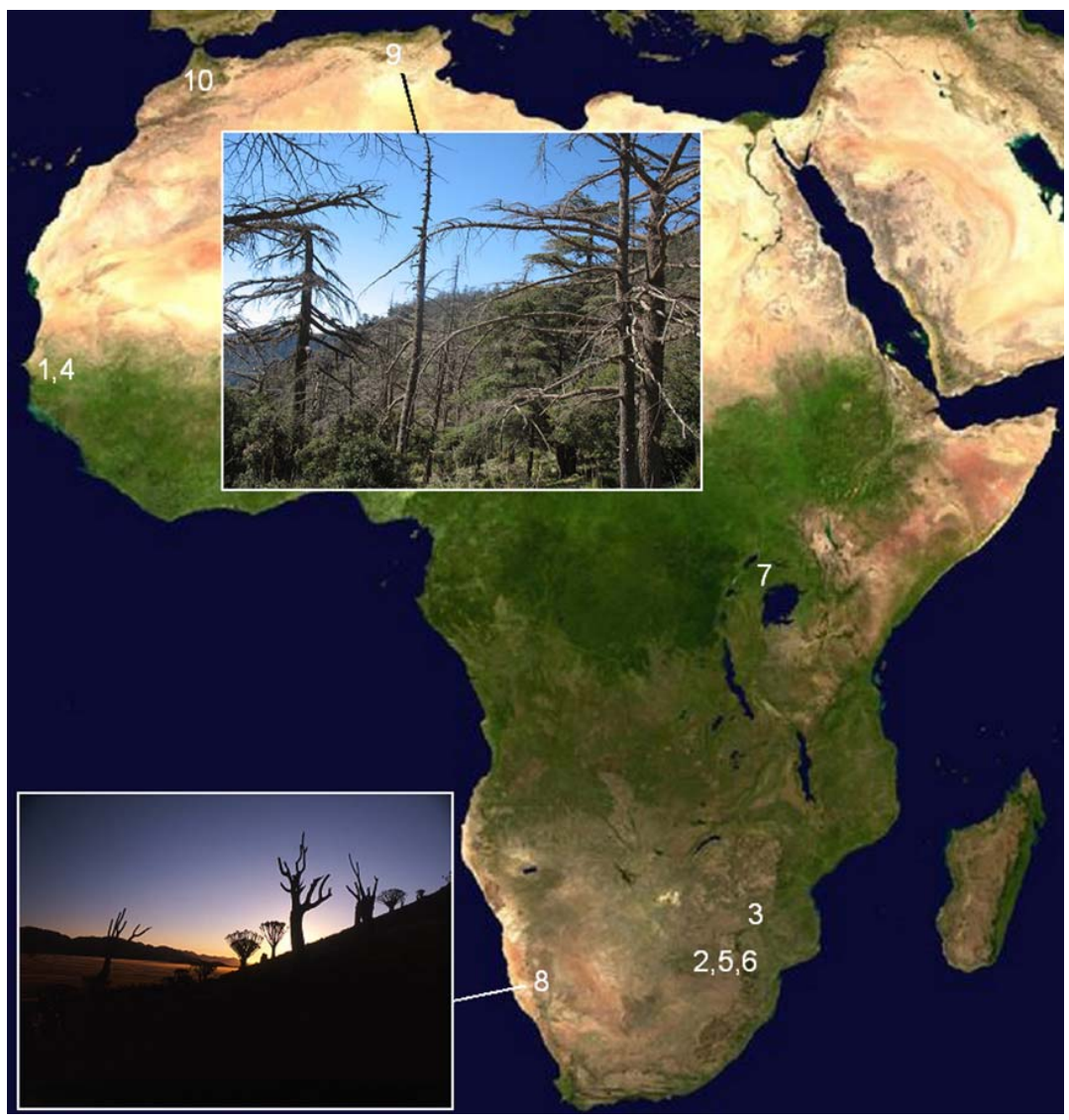

Fig. 2. Satellite map of Africa, with documented drought-induced mortality areas indicated with numbers, tied to Table A1 references. Upper photo: Cedrus atlantica die-off in Belezma National Park, Algeria; 2007, by Haroun Chenchouni. Lower photo: quiver tree (Aloe dichotoma) mortality in Tirasberg Mountains, Namibia; 2005, by Wendy Foden.

3.1.1.2. Asia. Reports of forest mortality in Asia (Fig. 4; Table A2) include death triggered by severe El Niño droughts in 1982/1983 and 1997/1998 in the tropical moist forests of both Malaysian and Indonesian Borneo (Leighton and Wirawan, 1986; Woods, 1989; Nakagawa et al., 2000; van Nieuwstadt and Sheil, 2005). Severe droughts are also associated with increased mortality among many tree species from tropical dry forests in northwest and southwest India (Khan et al., 1994), Abies koreana in South Korea (Lim et al., 2008), Juniperus procera from Saudia Arabia (Fisher, 1997), and pine and fir species in central Turkey (Semerci et al., 2008).
Recent droughts have triggered mortality of Pinus tabulaeformia across 0.5 million ha in east-central China (Wang et al., 2007), and across extensive areas of Pinus yunnanensis in southwest China (Li, 2003). The Russian Federal Forest Agency has mapped zones of forest health risk ("threat") across the Russian Federation, showing 338 million ha as "low threat", 260 million ha as "medium" threat, and 76 million ha of "high" threat, predominantly in southerly portions of the country (Kobelkov, 2008), where forest health problems due to drought appear to be concentrated (Ermolenko, 2008). 


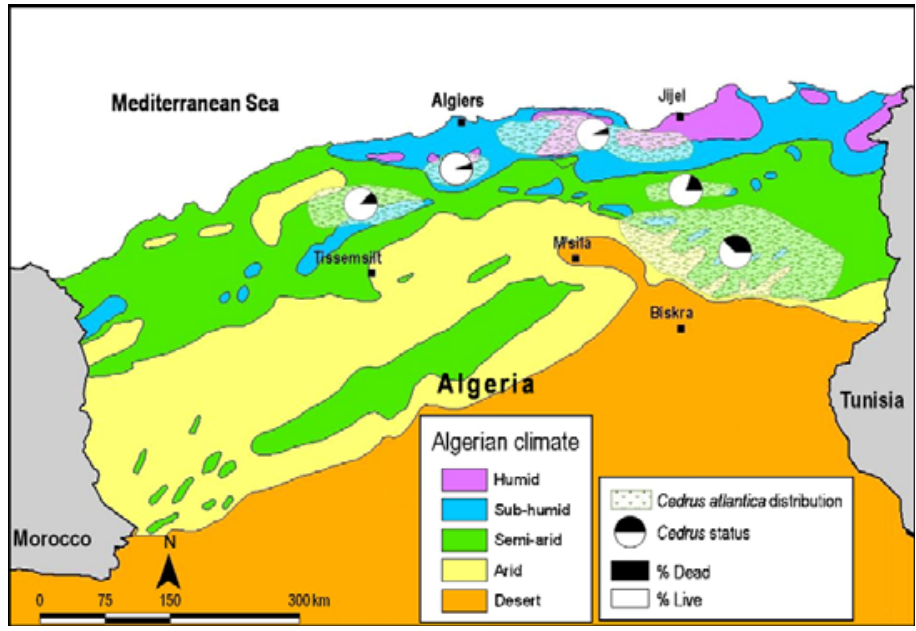

Fig. 3. Map of northern Algeria climate zones and mortality distribution of Cedrus atlantica. "Box 1 Atlas Cedar Die-off in Algeria" serves as the full caption.
Box 1. Atlas Cedar Die-off in Algeria Atlas cedar (Cedrus atlantica) occurs in northern Algeria, distributed in scattered montane populations near the limits of its bioclimatic tolerance between the Sahara Desert and the Mediterranean Sea (Fig. 3). Since the onset of severe drought from 1999 to 2002 cedar forests have undergone mass mortality, affecting all age classes (Bentouati, 2008). While all Algerian cedar forests are affected, the magnitude of mortality varies along a steep moisture gradient (Fig. 3), with die-off greatest (up to 100\%) in the drier mountains nearest the Sahara, dropping to much lower mortality levels in the moister coastal mountains (Chenchouni et al., 2008). Prolonged soil moisture deficits lead to decline and progressive death of cedar trees over a period of 1-3 years; a variety of insects and fungi have continued to kill weakened cedar trees since the drought eased after 2002 (Chenchouni et al., 2008). The Cedrus mortality began as small patches on drier aspects in the arid near-Sahara mountains, eventually coalescing into large patches affecting all ages on all exposures. In contrast, only small patches of old trees on dry aspects have died in more mesic regions near the coast. This recent drought also triggered substantial mortality in other Algerian tree species, including Pinus halepensis, Quercus ilex, Quercus suber, and Juniperus thurifera. Dendrochronological reconstructions of drought in Algeria show that this early 2000s dry period was the most severe drought since at least the middle of the 15th century (Touchan et al., 2008), consistent with climate change projections for a trend of increasing aridity in this region (Seager et al., 2007).

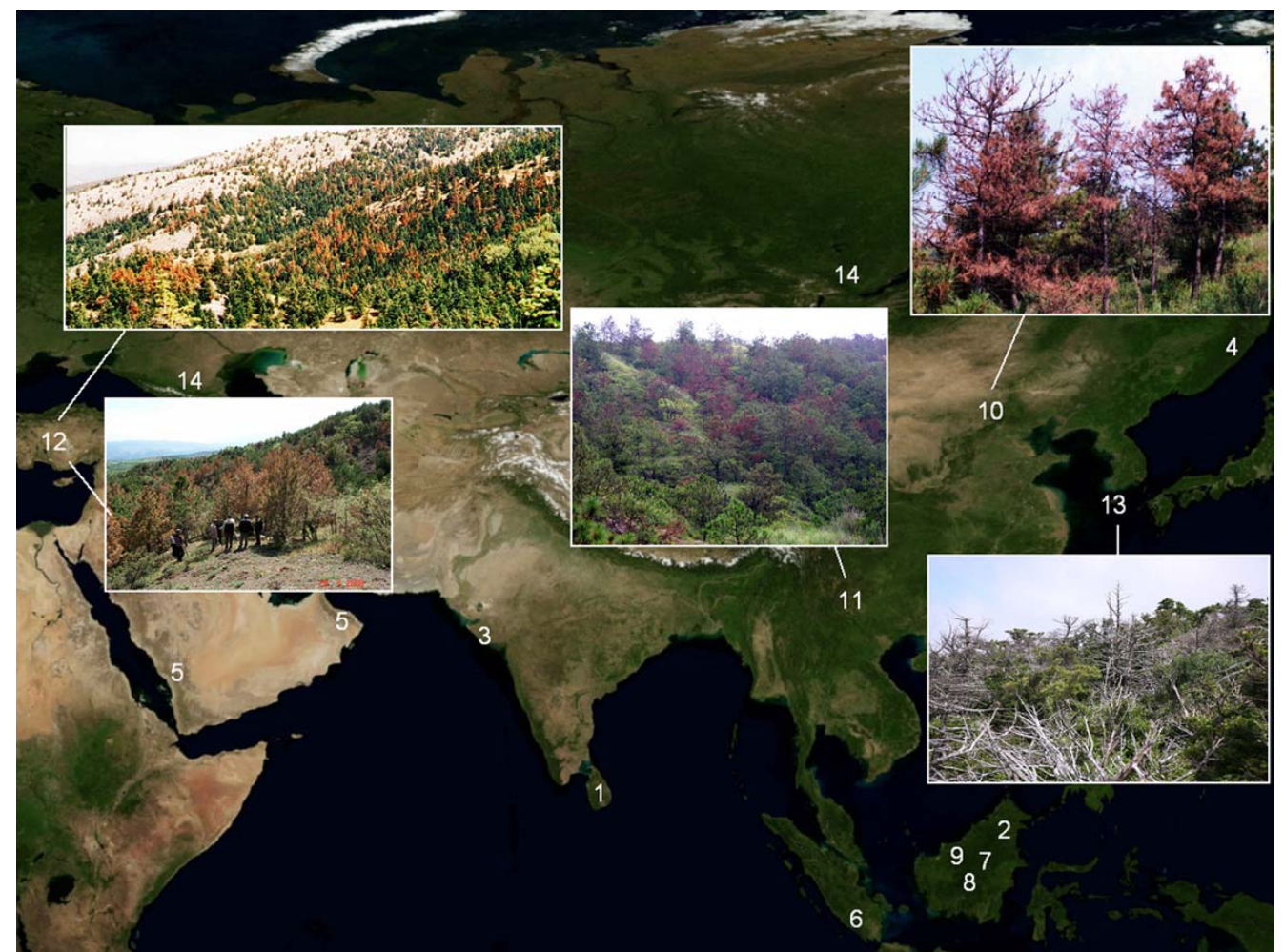

Fig. 4. Satellite map of Asia, with documented drought-induced mortality localities indicated with numbers, tied to Table A2 references. Lower $R$ Photo: Dead Abies koreana, Mount Halla, South Korea; 2008, by Jong-Hwan Lim. Upper R photo: Pinus tabulaeformis mortality in Shanxi Province, China; 2001, by Yugang Wang. Center photo: Dying Pinus yunnanensis in Yunnan Province, China; 2005, by Youqing Luo. Upper L photo; Abies cilicica mortality in the Bozkir-Konya region, Anatolia, Turkey; 2002, by Orphan Celik. Lower L photo: Dying Pinus nigra near Kastamonu, Anatolia, Turkey; 2008, by Akkin Semerci.

3.1.1.3. Australasia. In the sub-humid environments of northeast Australia (Fig. 5; Table A3), multi-year droughts have repeatedly triggered widespread Eucalyptus and Corymbia mortality (Fensham and Holman, 1999; Rice et al., 2004; Fensham and Fairfax,
2007), and have also caused tree death in Acacia woodlands (Fensham and Fairfax, 2005). There is also documentation of drought-induced mortality in temperate Nothofagus forests in New Zealand (Hosking and Hutcheson, 1988). 


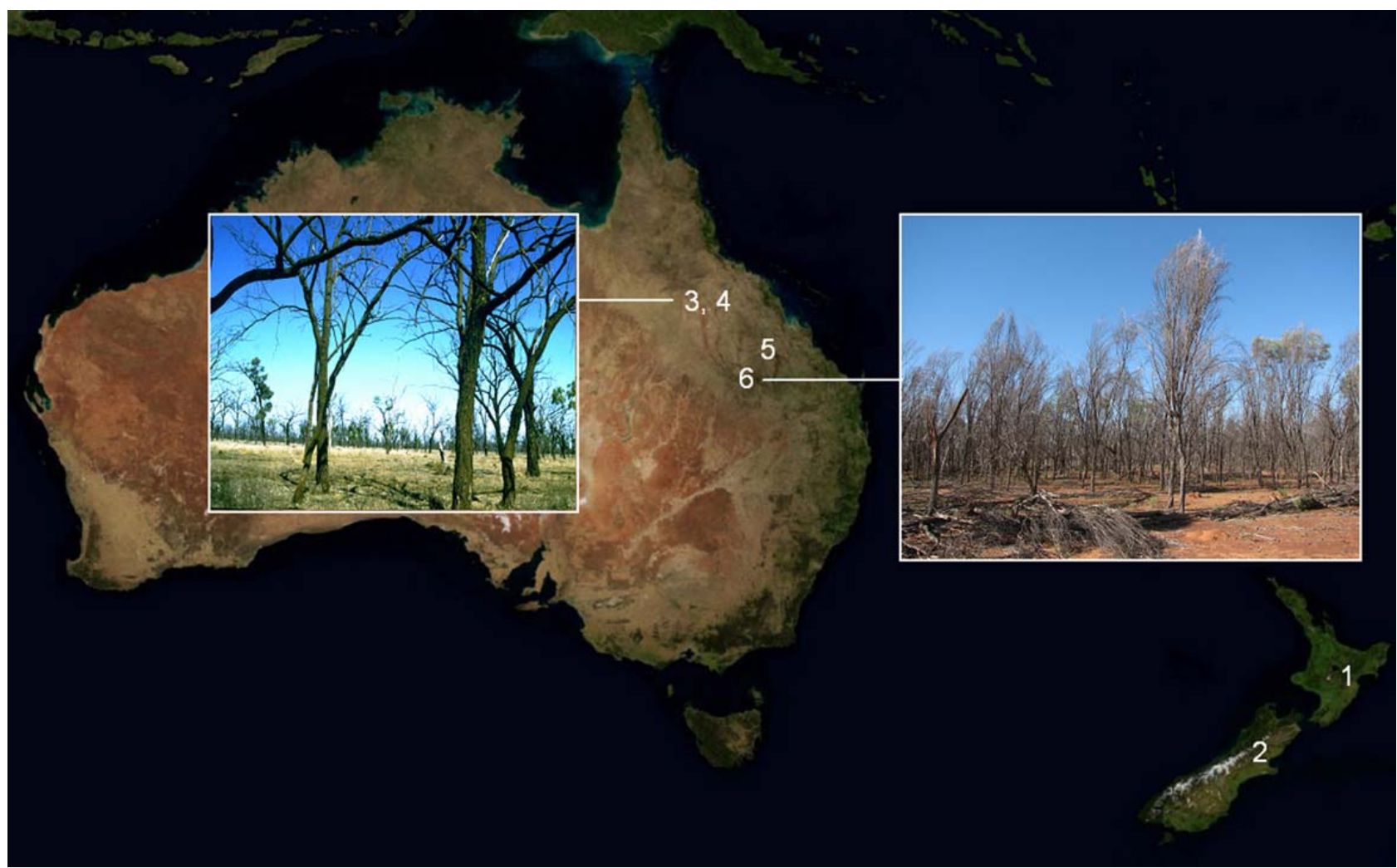

Fig. 5. Satellite map of Australasia, with documented drought-induced mortality areas indicated with numbers, tied to Table A3 references. $R$ photo: Die-off of mulga, Acacia aneura, the dominant tree across large areas of semi-arid Australia; 2007, by Rod Fensham. L photo: Eucalyptus xanthoclada mortality in Queensland, northeastern Australia; 1996, by Rod Fensham.

3.1.1.4. Europe. In Europe (Fig. 6; Table A4), forest mortality due to dry and warm conditions in the $1990 \mathrm{~s}$ and 2000s arcs across the Mediterranean regions, including increased death among many woody species in Spain (Peñuelas et al., 2001; Martinez-Vilalta and Piñol, 2002), increased mortality of oak, fir, spruce, beech, and pine species in France after the extreme heat wave and drought during the summer of 2003 (Breda et al., 2006; Landmann et al., 2006; Vennetier et al., 2007), and increases in mortality of Pinus sylvestris near the species' southern range limits in Switzerland and Italy (Dobbertin and Rigling, 2006; Bigler et al., 2006; Vertui and Tagliaferro, 1998).

A severe drought in 2000 killed many Abies cephalonica in mainland Greece (Tsopelas et al., 2004) and Pinus halepensis sub. brutia - the most drought tolerant of the Mediterranean pines - in eastern Greece (Körner et al., 2005). Farther north, summer drought paired with biotic stressors has been linked to mortality of Quercus robur in Poland (Siwecki and Ufnalksi, 1998), Picea abies in southeast Norway (Solberg, 2004), and with a severe die-off of Picea obovata in northwest Russia (Kauhanen et al., 2008; Ogibin and Demidova, in press).
3.1.1.5. North America. Climate-induced tree mortality and forest die-off is relatively well documented for North America (Fig. 7; Table A5). Drought and warmth across western North America in the last decade have led to extensive insect outbreaks and mortality in many forest types throughout the region, affecting 20 million ha and many tree species since 1997 from Alaska to Mexico (Raffa et al., 2008; Bentz et al., 2009). Examples of forest die-off range from $>1$ million ha of multiple spruce species in Alaska (Berg et al., 2006) and $>10$ million ha of Pinus contorta in British Columbia (Kurz et al., 2008a), to droughtinduced Populus tremuloides mortality across a million hectares in Saskatchewan and Alberta (Hogg et al., 2008). In the southwestern U.S., die-off of Pinus edulis on over a million hectares was specifically linked to "global-change-type drought" (Breshears et al., 2005). In the eastern portion of the continent, declines and increased mortality among oaks, particularly in the red oak family, have been reported from Missouri (Voelker et al., 2008) to South Carolina (Clinton et al., 1993) in relation to multi-year and seasonal droughts in the 1980s-2000s. Drought during the 1980s followed by an unusual spring thaw in eastern North America also contributed to decline and mortality of maples in Quebec (Hendershot and Jones, 1989). In addition, recent increases in background rates of tree mortality across the western U.S. have been attributed to elevated temperatures (van Mantgem et al., 2009). 


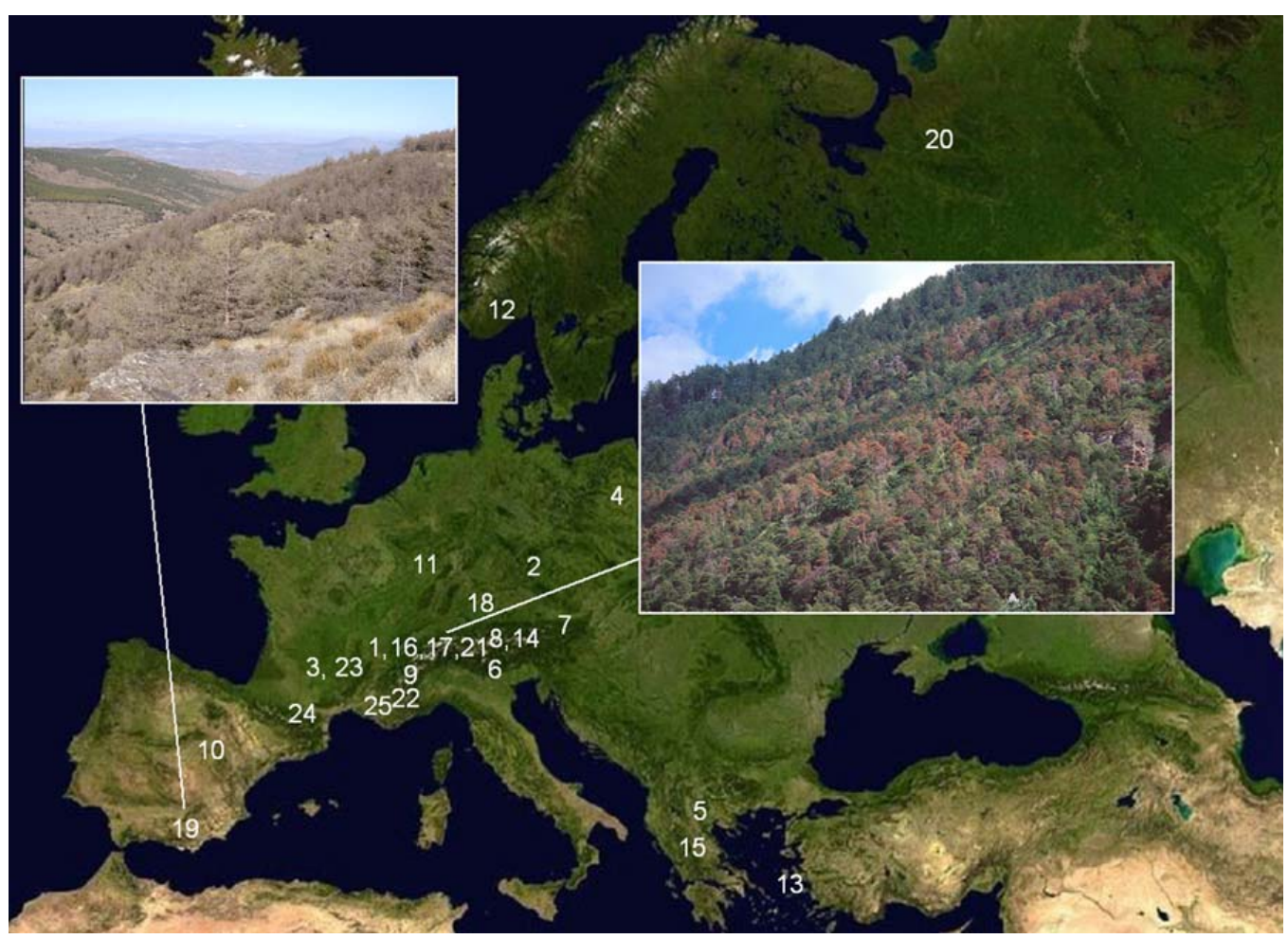

Fig. 6. Satellite map of Europe, with documented drought-induced mortality areas indicated with numbers, tied to Table A4 references. R photo: Pinus sylvestris mortality, Valais, Switzerland; 1999, by Beat Wermelinger. L photo: Pinus sylvestris die-off, Sierra de los Filabres, Spain; 2006, by Rafael Navarro-Cerrillo.

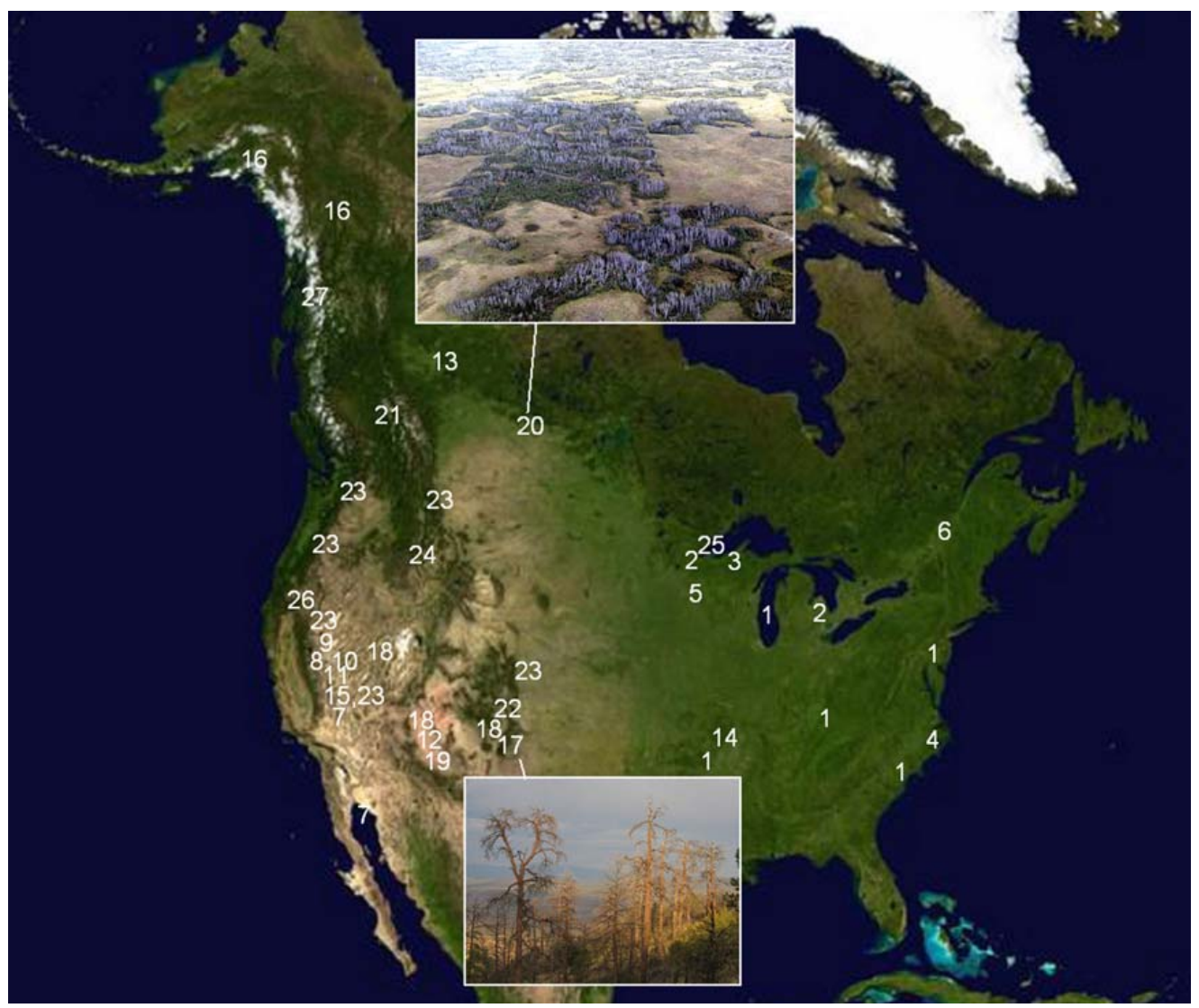

Fig. 7. Satellite map of North America, with documented drought-induced mortality localities indicated with numbers, tied to Table A5 references. Top photo: Aerial view showing severe mortality of aspen (Populus tremuloides) in the parkland zone of Alberta, Canada; 2004, by Michael Michaelian. Lower photo: Pinus ponderosa die-off, Jemez Mountains, New Mexico, USA; 2006, by Craig D. Allen. 
3.1.1.6. South and Central America. In Latin America (Fig. 8; Table A6), ENSO-related seasonal droughts have amplified background tree mortality rates in tropical forests of Costa Rica (Chazdon et al., 2005), Panama (Condit et al., 1995), northwest Brazil (Williamson et al., 2000), and southeast Brazil (Rolim et al., 2005), and caused extensive mortality of Nothofagus dombeyi in Patagonian South America
(Suarez et al., 2004). A hot and severe drought across the Amazon basin in 2005, linked to anomalously warm sea surface temperatures in the North Atlantic, has also recently been tied to regionally extensive increases in tree mortality rates and subsequent aboveground biomass loss, indicating vulnerability of Amazonian forests to moisture stress (Phillips et al., 2009) (Fig. 9).

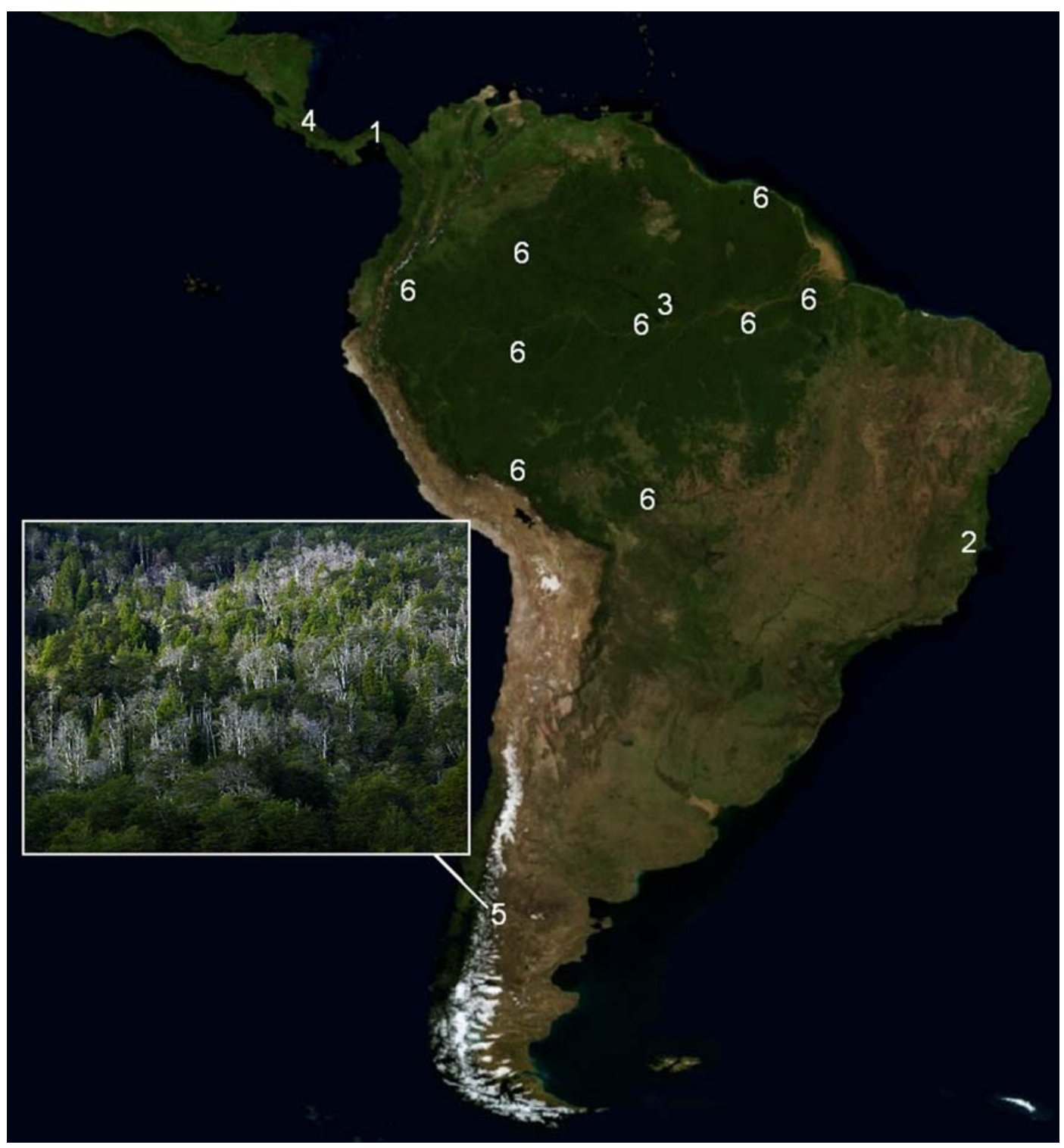

Fig. 8. Satellite map of South and Central America, with documented drought-induced mortality localities indicated with numbers, tied to Table A6 references. Photo: Nothofagus dombeyi mortality at Rio Manso Inferior, northern Patagonia, Argentina; 2004, by Thomas Kitzberger.

\subsubsection{Spatial and temporal patterns of mortality}

Climate-induced mortality events in this review include examples that span a broad gradient of woody ecosystems, from monsoonal savannas with mean precipitation $<400 \mathrm{~mm} /$ year, to subalpine conifer forests with a Mediterranean climate, to tropical rainforests with mean precipitation $>3000 \mathrm{~mm} /$ year.
These cases reveal a complex set of mortality patterns in response to drought and heat stress, ranging from modest and short-lived local increases in background mortality rates to episodes of acute, regional-scale forest die-off, which often (but not always) involve biotic agents like insect outbreaks. 


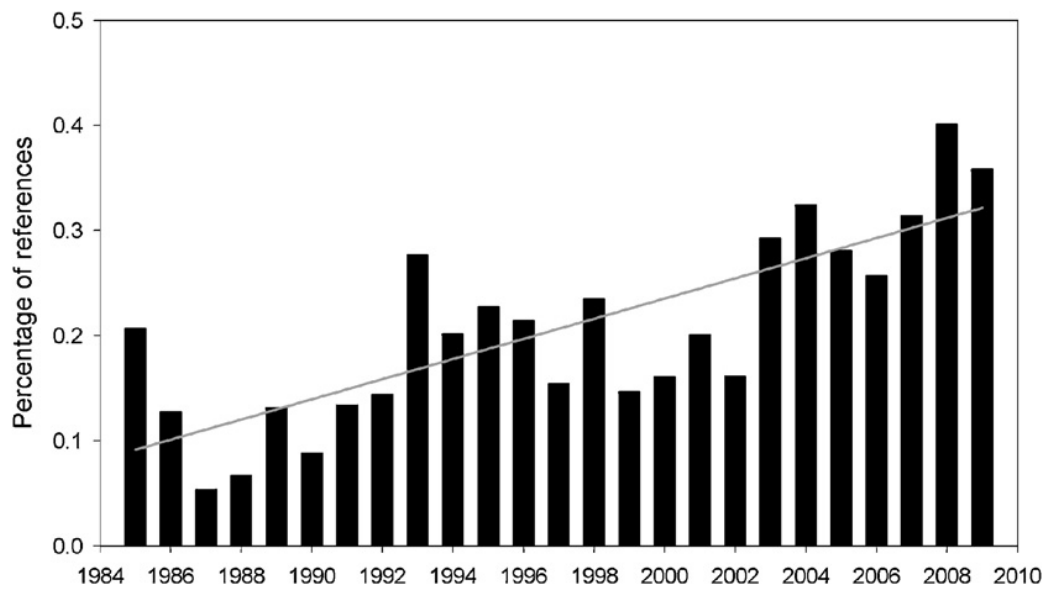

Fig. 9. ISI Web of Science search of the trend in published reports of climate-related forest mortality in the scientific literature, for the years 1985-2009. Plotted bars show the percent of references using the topic words "forest AND mortality AND drought", relative to all "forest" references. Line represents the linear regression model fitted to the data $(R 2=0.61 ; F=35.73 ; p<0.001)$.

At broad spatial scales, drought-related forest mortality has been reported near species geographic or elevational range margins where climatic factors (particularly water stress) are often presumed to be limiting (Allen and Breshears, 1998; Foden et al., 2007; Jump et al., 2009; Fig. 1; Fig. 3 and linked Box 1). Spatially extensive die-offs are commonly associated with prolonged water deficits, such as in savanna and temperate conifer forest vegetation types during multi-year droughts (Fensham et al., 2009; Fig. 10). Notably, however, drought-induced mortality is not restricted to forests typically thought to be waterlimited, as highlighted by events in tropical rainforests of Borneo where stand-level mortality reached as high as $26 \%$ after the severe El Niño in 1997/1998 (van Nieuwstadt and Sheil, 2005), or the Amazon basin in 2005 (Phillips et al., 2009). Mortality in ever-wet and seasonally dry tropical rainforests appears to be relatively diffuse and incited most often by short but extreme seasonal droughts (Fig. 10). In temperate forests, short (seasonal) droughts may be more likely to induce dieback of broadleaved (deciduous angiosperm) trees (Fig. 10) than conifer (evergreen needleleaf) trees because of their increased vulnerability to xylem cavitation (Maherali et al., 2004).

Patterns of tree death are often quite patchy at finer spatial scales across the synoptic region where drought occurs. Although mortality is sometimes greatest in locally dry landscape positions (Oberhuber, 2001; Dobbertin et al., 2005; Worrall et al., 2008), ecosite variability (soils, elevation, aspect, slope, topographic position) may interact with density-dependent processes such as insect outbreaks, competition, or facilitation to produce complex spatial patterns of mortality at the stand and forest scale (Fensham and Holman, 1999; Lloret et al., 2004). Greater mortality can occur, for example, on more favorable sites within the middle of geographic and landscape distributions where higher tree density drives increased competition for water or elevated insect activity (Guarin and Taylor, 2005; Greenwood and Weisberg, 2008; Fensham et al., 2009; Horner et al., 2009; Klos et al., 2009). However, high severity drought can drive extensive forest mortality independent of tree density (Floyd et al., 2009). Higher mortality rates can also occur on favorable sites where trees do not invest in adequate root systems or where they otherwise become hydraulically overextended (Ogle et al., 2000; Fensham and Fairfax, 2007; Nepstad et al., 2007).

Spatial patterns of mortality at the stand and forest scale are also heavily influenced by life-history traits and tolerances of individual species within forests, with drought commonly triggering differential mortality rates between co-occurring tree species (Suarez et al., 2004; Gitlin et al., 2006; Fensham and Fairfax, 2007; Newbery and Lingenfelder, 2009; Phillips et al., 2009). Larger and/or older trees often appear more prone to drought-induced mortality (Mueller et al., 2005; Nepstad et al., 2007; Floyd et al., 2009), although this relationship is species-dependent, and in cases where stands are undergoing intense self-thinning, smaller sub-dominant trees and saplings are often more affected (Kloeppel et al., 2003; Elliott and Swank, 1994; Hanson and Weltzin, 2000).

Temporal patterns of drought-related tree mortality also can be difficult to interpret due to lagged responses in some species, in which mortality has been shown to occur years or even decades after drought stress (Pedersen, 1998, 1999; Bigler et al., 2007). Furthermore, the long-lived nature of trees and their ability to shift allocation of resources and change their hydraulic architecture throughout their lives can result in non-linear responses to drought stress in both space and time. Different sequences of climate events may also affect the risk of mortality (Miao et al., 2009). 


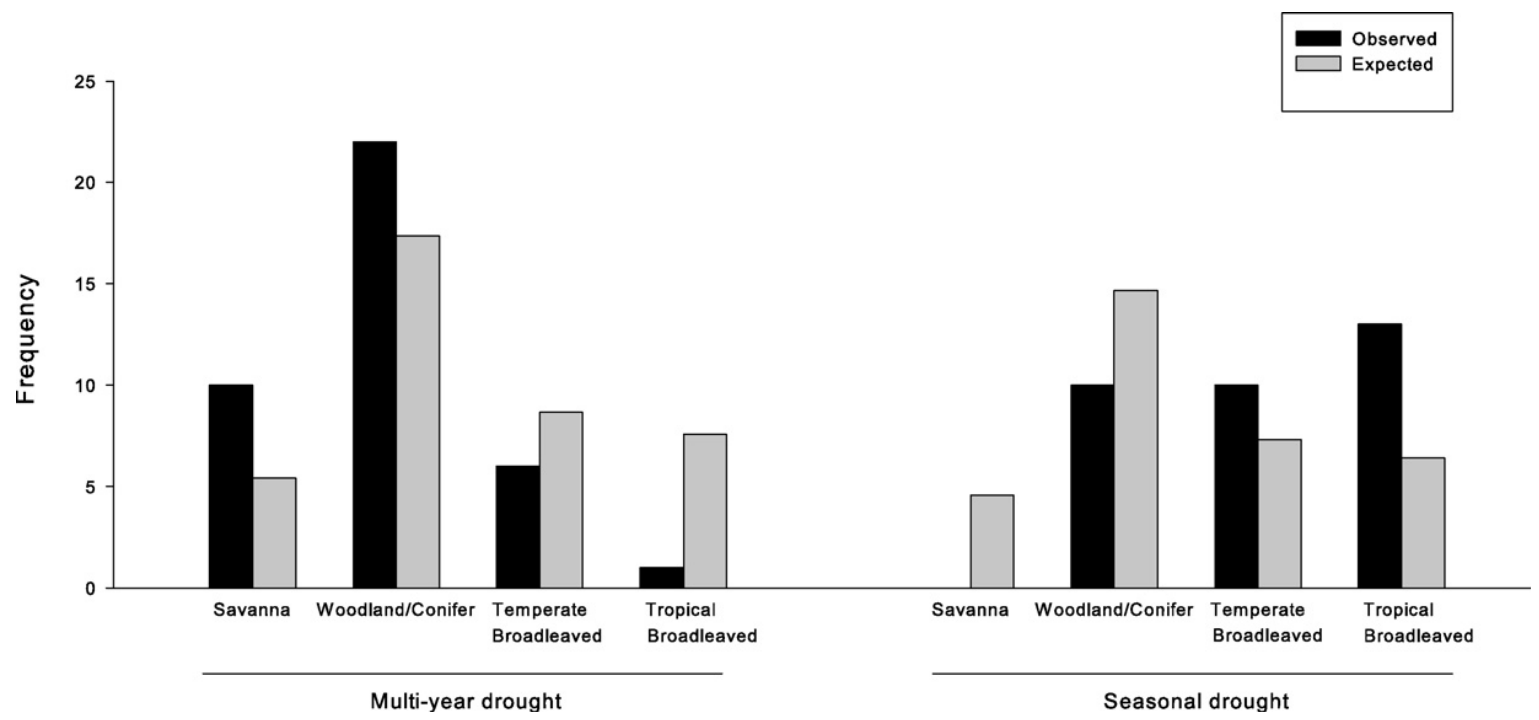

Fig. 10. Differences between observed and expected frequencies of reported forest mortality cases listed in Tables A1A6, sorted by duration of associated drought events (seasonal vs. multi-year), with forests grouped into four major biomes. Mortality discriminated by forest type is dependent on drought duration, with more drought-adapted forest types showing mortality during long droughts and less drought-adapted forest types showing more mortality cases during short-term seasonal droughts. Pearson Chisquare $=23.46, d f=3, p=0.000012$.

\section{Discussion}

\subsection{Climate-induced forest mortality : are new trends emerging?}

The diverse instances of mortality reported here clearly illustrate that drought and heat can impact trees in many forest types. However awareness of, and interest in, climate-induced forest mortality and dieback is not new (Auclair, 1993; Ciesla and Donaubauer, 1994). Past die-offs have been extensively documented. Historic examples include: widespread death of Eucalyptus, Acacia, and Callitris species in the early 1900 s triggered by the worst drought of the instrumental record in northeastern Australia (Fensham and Holman, 1999); Nothofagus mortality during 1914-1915 in New Zealand (Grant, 1984); Picea meyeri mortality during the 1920 s in northern China (Liang et al., 2003); extensive tree mortality in the southern Appalachian Mountains and the Great Plains during the dust-bowl droughts of the 1920s- 1930s (Hursh and Haasis, 1931; Albertson and Weaver, 1945); Pinus sylvestris death during 1940-1955 in Switzerland (Dobbertin et al., 2007); oak mortality in many European countries following severe droughts episodes in 1892-1897, 1910-1917, 1922-1927, 19461949, 1955-1961 (Delatour, 1983); extensive tree mortality of Austrocedrus chilensis during El Niño droughts in the 1910s, 1942-1943, and the 1950s in Argentina (Villalba and Veblen, 1998); and die-off of multiple pine species during the 1950s drought in the southwestern USA (Swetnam and Betancourt, 1998; Allen and Breshears, 1998). Furthermore, the overwrought perception of unprecedented forest decline and impending death due to air pollution in central Europe (where it was referred to as 'Waldsterben') and eastern North America that received much attention in the 1980 s provides a cautionary example of exaggerated claims of widespread forest health risk in the absence of adequate evidence (Skelly and Innes, 1994).

So are recent occurrences of die-off simply welldocumented examples of a natural phenomenon linked to climate variability, or is global climate change driving increases in forest mortality? We recognize that the available data on climate-induced forest mortality have many limitations: our examples represent a compilation of idiosyncratic case studies with uneven geographic coverage. The studies differed greatly in their goals, methods, and definitions of mortality, and inconsistently report mortality rates, spatial scale and patterns of mortality, and severity parameters of climate stress. The recent increase in forest mortality reports that we document could merely be an artifact of more scientific attention on climate change, perhaps in concert with a few high profile cases of climate-related forest die-off. These limitations, and the lack of any systematic global monitoring program, currently constrain our ability to determine if global changes in forest mortality are emerging.

Even though our review is insufficient to make unequivocal causal attributions, our data are consistent with the possibility that climate change is contributing to an increase in reported mortality. Documentation of climate-related forest mortality in association with recent warming and droughts is rising rapidly (Fig. 9), and in some of these cases the droughts have been the most severe of the last few centuries. Furthermore, recent research indicates that warmer temperatures alone can increase forest water stress independent of precipitation amount (Barber et al., 2000). In addition, new experimental results show that warmer 
temperatures can greatly accelerate drought-induced mortality (Adams et al., 2009, and associated correspondence). If the recent increase in mortality reports is indeed driven in part by global climate change, far greater chronic forest stress and mortality risk should be expected in coming decades due to the large increases in mean temperature and significant long-term regional drying projected in some places by 2100 , in addition to projected increases in the frequency of extreme events such as severe droughts, hot extremes, and heat waves (IPCC, 2007a; Jentsch et al., 2007; Sterl et al., 2008).

\subsection{Climate and plant physiological interactions that drive forest mortality}

Understanding complex spatial and temporal patterns of climate-induced tree death and forest die-off requires knowledge of the physiological drivers of tree mortality. The fundamental mechanisms underlying tree survival and mortality during drought remain poorly understood despite decades of research within the fields of forestry, pathology, entomology, and ecology (Waring, 1987; Manion, 1991; MuellerDombois, 1986,1988; Breda et al., 2006; Ogaya and Peñuelas, 2007; McDowell et al., 2008). Part of the challenge is that tree mortality commonly involves multiple, interacting factors, ranging from particular sequences of climate stress and stand life histories to insect pests and diseases (Franklin et al., 1987; Miao et al., 2009). Based on the decline spiral model (Manion, 1991; Manion and Lachance, 1992), drought can operate as a trigger ("inciting factor") that may ultimately lead to mortality in trees that are already under stress (by "predisposing factors" such as old age, poor site conditions and air pollution) and succumb to subsequent stem and root damage by biotic agents ("contributing factors" such as wood-boring insects and fungal pathogens). McDowell et al. (2008) build upon Manion's framework to postulate three mutually non-exclusive mechanisms by which drought could lead to broad-scale forest mortality: (1) extreme drought and heat kill trees through cavitation of water columns within the xylem (Rennenberg et al., 2006; Zweifel and Zeugin, 2008); (2) protracted water stress drives plant carbon deficits and metabolic limitations that lead to carbon starvation and reduced ability to defend against attack by biotic agents such as insects or fungi (McDowell et al., 2008; Breshears et al., 2009; Adams et al., 2009); and (3) extended warmth during droughts can drive increased population abundance in these biotic agents, allowing them to overwhelm their already stressed tree hosts (Desprez-Loustau et al., 2006; Raffa et al., 2008; Wermelinger et al., 2008). Although these hypotheses have growing support, our physiological knowledge remains inadequate for confidently predicting patterns of regional die-off, as well as variation in survival for trees within the same stand.

The degree to which trees regulate water loss during drought may explain patterns of carbohydrate (and resin) production and subsequent susceptibility to drought or biotic attack (McDowell et al., 2008; Zweifel et al., 2009). A continuum of stomatal responses to drought exist from drought avoidance (isohydry), in which stomata close at a threshold water potential to minimize further transpiration, to drought tolerance (anisohydry), in which stomatal closure is less severe and transpiration continues at relatively high rates (McDowell et al., 2008). The isohydric response protects xylem from cavitation through avoidance of severe low water potentials, but can cause eventual carbon starvation as stomatal closure shuts down photosynthesis while respiration costs continue to deplete carbon stores. The anisohydric response can allow continued carbon gain through maintaining open stomata but at greater risk of cavitation, which might kill trees directly or could increase the likelihood of future carbon deficits. Plants that typify each response have associated traits consistent with their mode of stomatal regulation, such as deep rooting access to more reliable soil water and cavitation-resistant xylem for drought-tolerant species.

In addition to hydraulic failure and carbon starvation, a third physiological mechanism predisposing plants to mortality may exist - cellular metabolism limitation. This hypothesis suggests that low tissue water potentials during drought may constrain cell metabolism (Würth et al., 2005; Ryan et al., 2006; Sala and Hoch, 2009), thereby preventing the production and translocation of carbohydrates, resins, and other secondary metabolites necessary for plant defense against biotic attack. The common observation that trees which succumb to insect attacks have weak resin flow and are unable to pitch out attacking insects is consistent with constraints on photosynthetic carbon uptake, cellular carbon metabolism, and/or tree water relations. A likely sequence for many isohydric species that is consistent with Manion's cascade (Manion, 1991) is that climate stressed trees starve for carbon, perhaps due to poor edaphic position combined with drought, which causes poor resin flow and an inability to defend against insect attack, which subsequently allows fungi that are symbiotic with the beetles to colonize and occlude the sapwood, causing transpiration to cease, drying of the canopy, and eventual mortality (McDowell et al., 2008, 2009).

The observation that climate-induced tree mortality is happening not only in semi-arid regions but also in mesic forests suggests that the global rise in temperature may be a common driver (van Mantgemet al., 2009; Adams et al., 2009). The mechanisms by which rising temperature in the absence of severe precipitation deficits may result in increased tree mortality include impacts on both host physiology and biotic agents. Increasing temperature raises the vapor pressure deficit and evaporation to the atmosphere. This results in increased water loss through transpiration and either stomatal closure in the case of isohydric species, or decreased margin of safety from hydraulic failure in the case of anisohydric species. 
Rising temperatures may impact the carbon storage of trees in a particularly negative way because the rate of carbohydrate consumption required to maintain cellular metabolism (respiration) is strongly linked to temperature (Amthor, 2000). The first experiment under controlled climate to isolate the effect of temperature on drought-induced tree mortality, conducted on Pinus edulis, indicates a high degree of sensitivity to elevated temperature and indirectly implicates carbon starvation (Adams et al., 2009).

Warmer temperatures may also be important where cold winters are usual, in that abnormally warm winter temperatures maintain significant physiological activity after the growth season, with tree respiration costs wasting stored carbohydrates (Damesin, 2003). Even though $\mathrm{CO} 2$ uptake can occur during mild winters and partially compensate for carbon loss during summer droughts (Holst et al., 2008), the annual C balance often remains in deficit under these conditions. Therefore under climatic warming scenarios, droughtavoiding tree species may move closer to carbon starvation, and drought-tolerant species may come closer to hydraulic failure (McDowell et al., 2008).

Presumably, surviving individuals after a severe climate event would have some degree of genetic drought resistance that would be inherited by the next generation (Gutschick and BassiriRad, 2003; Parmesan, 2006; Millar et al., 2007a). But the adaptation of a tree species to a markedly different local climate, with only one or a few generations per century, may be too slow to successfully respond to the rapid present rate of climate change.

Warming temperatures also have direct effects on insect population dynamics - in particular, outbreaks of some aggressive bark beetle species are closely tied to temperature (Logan et al., 2003; Berg et al., 2006; Hicke et al., 2006; Rouault et al., 2006). Higher temperatures can accelerate insect development and reproduction, increasing infestation pressure directly (e.g., Wermelinger and Seifert, 1999; Bale et al., 2002; Caldeira et al., 2002; Gan, 2004), while at the same time heat-induced drought stress may reduce tree vigor and increase host susceptibility to insect attack (Mattson and Haack, 1987; Rouault et al., 2006). Warming temperatures and drought-stressed trees also may foster increased mortality from non-insect pathogens, particularly fungi (Ayres and Lombardero, 2000; Desprez-Loustau et al., 2006; Garrett et al., 2006). However, fungal responses to climatic factors are complex and uncertain because of interactions with tree host susceptibility and insect vectors, and some fungi-tree relationships are difficult to assess because important belowground interactions between fungi and tree roots are not well studied.

\subsection{Consequences of broad-scale forest mortality}

Due to the increasingly tight coupling of human and environmental systems, the consequences of broadscale forest mortality are important to contemplate.
Trees grow relatively slowly but can die quickly: a 200-year-old tree may be killed by severe drought within a few months to a few years. Therefore, mortality of adult trees can result in ecosystem changes far more rapidly than a gradual transition driven by tree regeneration and growth (Fig. 11). If forests are forced to adjust abruptly to new climate conditions through forest die-off, many pervasive and persistent ecological and social effects will result. Major changes in understory species may occur (Rich et al., 2008), as well as the possible development of novel ecosystems due to new combinations of native and invasive exotic trees that, depending on the climatic tolerances of seedlings, eventually repopulate the overstory (Walther et al., 2005; Millar et al., 2007b; Suarez and Kitzberger, 2008).

Abiotic ecosystem impacts may include changes in solar energy fluxes reaching ground level and reflecting back to the atmosphere, with potentially large feedbacks to regional climate in some areas (Bonan, 2008; Chapin et al., 2008), aswell as alterations in hydrology and ecosystem water budgets due to increases in evaporation and reductions in transpiration (e.g., Huxman et al., 2005), and changes in groundwater recharge. Potential effects of extensive forest mortality on water resource availability could have large effects on human societies (Millennium Ecosystem Assessment, 2005).

In addition, broad-scale forest mortality could change local, regional, and global carbon budgets (Breshears and Allen, 2002; Jones et al., 2009). Forests store considerably more carbon than the atmosphere, and forest die-off could redistribute within-ecosystem carbon pools and release pulses of carbon back to the atmosphere. A recent modeling study simulated this type of transformation in managed forests of Canada, where climate-related increases in fire and insect disturbance are forecast to turn these forests into a net carbon source (Kurz et al., 2008b).

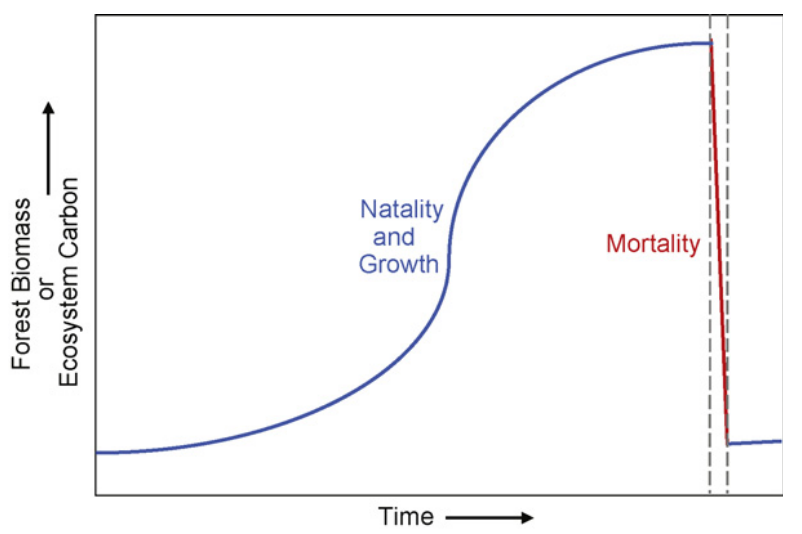

Fig. 11. Abrupt reductions in forest biomass (or ecosystem carbon) can result from drought-induced forest die-off and occur more rapidly than the relatively slow countervailing biomass increments from tree natality and growth. Trajectories of change vary with ecosystem, as do minimum biomass and carbon values, and are not to scale in this conceptual figure. 
Meanwhile, climate-related increases in the spatial extent of mass tree mortality by insects, notably mountain pine beetle, have recently transformed some forests of interior British Columbia (Canada) from a net carbon sink into a net carbon source (Kurz et al., 2008a). Similarly, it is possible that "widespread forest collapse via drought" could transform the world's tropical forests from a net carbon sink into a large net source during this century (Lewis, 2006, p. 195; cf. Phillips et al., 2009; Jones et al., 2009). Land-use impacts such as anthropogenic fires and forest fragmentation, interacting with climate-induced forest stress, are likely to amplify these effects in some regions, including the Amazon Basin (Nepstad et al., 2008). Overall, climate-induced forest mortality and related disturbances will increase global carbon flux rates at least temporarily, potentially undermining the capacity of the world's forests to act as carbon sinks in the coming centuries.

Past forest management may have exacerbated recent mortality in some regions. In portions of western North America, over a century of fire suppression has fostered the buildup of unusually high tree densities. Trees in these unnaturally dense forests can have decreased vigor, which can increase their vulnerability to multiple mortality factors (Savage, 1997). Extensive reforestations with pine plantations in regions such as China and the Mediterranean Basin (e.g., 3.5 million ha reforested with conifers since 1940 in Spain alone; J. Castro - from agency statistical sources) may be particularly vulnerable, especially because some of these plantations are on marginal sites given the excessive densities and unknown genetic provenances of the trees.

In summary, given the potential risks of climateinduced forest die-off, forest managers need to develop adaptation strategies to improve the resistance and resilience of forests to projected increases in climate stress (Seppala et al., 2009). Options might include thinning stands to reduce competition, selection of appropriate genotypes (e.g., improved drought resistance), and even translocation of species to match expected climate changes (e.g. Millar et al., 2007b; Joyce et al., 2008; Richardson et al., 2009).

\subsection{Key information gaps and scientific uncertainties}

The conclusions that can be drawn about recent trends in tree mortality and the predictions that can be made about future climate-induced forest die-off are limited by a number of key information gaps and scientific uncertainties.

(1) Accurate documentation of global forest mortality patterns and trends requires the establishment of a worldwide monitoring program. Despite many national and regional forest-monitoring efforts (e.g., the European Union's intensive forest health monitoring EU/ICP-Forests Level II network), there is an absence of adequate data on forest health status globally (FAO, 2006, 2007). Existing permanent sample plot networks can detect large scale events or a generalized background mortality increase, but are not designed to detect and assess patchy mortality, even at rather high rates, as is common when forest landscapes are heterogeneous and inmost of the cases of biotic agent outbreaks. Reliable, long-term, global-scale forest health monitoring, likely combining remote-sensing and ground-based measurements in a methodologically coordinated and consistent manner, is needed to accurately determine the status and trends of forest stress and mortality on planet Earth. Regional and global maps of actual patterns of climate-induced tree mortality are also vitally important for the development and validation of models for predicting forest die-off in response to climate change.

(2) Understanding the mechanisms by which climate change may affect forests requires quantitative knowledge of the physiological thresholds of individual tree mortality under chronic or acute water stress (Fig. 12). With the exception of information for a few tree species (McDowell et al., 2008; Zweifel et al., 2009), there is surprisingly little species-specific knowledge on regulation of xylem water potentials; therefore, placing various species on the continuum of isohydry-anisohydry is difficult, and predicting how diverse species differentially experience carbon starvation or hydraulic failure is currently impossible.

Similarly, there is almost no knowledge on the patterns or mechanisms of carbohydrate storage in response to drought and heat. The potential effects of other components of changing atmospheric chemistry (e.g., elevated levels of nitrogen deposition and ground-level ozone) on the sensitivity of trees to drought remain inadequately known (Grulke et al., 2009). Research is also needed on how tree phenologies will respond to climate warming, because increasing winter temperatures may contribute to depletion of carbohydrate reserves relevant to carbon starvation thresholds. In addition, better knowledge is needed on within-species genetic variability and selection of trees related to drought and heat stress.

(3) More accurate global vegetation maps are needed as essential inputs to calibrate and validate dynamic global vegetation models. The extent of forest mortality can only be documented or modeled if there is precise information on the locations and extent of pre-die-off forests.

(4) Spatially explicit documentation of environmental conditions in areas of forest die-off is necessary to link mortality to causal climate drivers, including precipitation, temperature, and vapour pressure deficit. Given the difficulties in measuring precipitation and the absence of reliable soil datasets at adequate resolutions for continental-scale studies, a robust water availability index, possibly derived from remote sensing, is needed to help modelers simulate water stress in trees. In order to disentangle moisture deficit from temperature effects on tree mortality, more research is also needed to relate spatial gradients of mortality to variation in temperature. This research might utilize historical and dendrochronological records across spatial and temporal gradients where 
variations in rainfall deficit and temperature increase are expressed.

(5) Mechanistic understanding of climate-induced tree mortality requires improved knowledge of belowground processes and soil moisture conditions (e.g. Brunner et al., 2009). Models often include detailed algorithms describing aboveground physiological processes but treat belowground processes as a "black box". Understanding of the impacts of increasing atmospheric $\mathrm{CO} 2$, nitrogen deposition, ground-level ozone, and drought on root dynamics, productivity, exudation fluxes, and mycorrhizal interactions would particularly improve belowground modeling.

(6) The direct effects of climate on the population dynamics of almost all forest insect pests and other biotic disturbance agents remain poorly understood but are important to modeling climate-induced forest mortality (Wermelinger and Seiffert, 1999; Logan et al., 2003; Desprez-Loustauetal.,2006; Bredaetal.,2006; Bentzetal.,2009). Generalization through synthesis of current knowledge on the dynamics of damaging biotic agents and tree response to attacks could improve existing mortality functions in forest models.

(7) Feedbacks between physiological stress (and tree mortality) driven by climate and other forest disturbance processes (e.g., insect outbreaks, fire) are poorly understood (Allen, 2007). These major disturbance processes may increasingly drive the mortality dynamics of forests in a rapidly changing climate, necessitating improved modeling of their cumulative and collective effects (Nepstad et al., 2008). Current models of vegetation response to climate change share weaknesses associated with the knowledge gaps identified here, including individual tree-based process models (Keane et al., 2001), species-specific empirical models (climate envelope models, e.g., Hamann and Wang, 2005; Thuiller et al., 2008), climate envelope threshold models linked to plant functional types in dynamic global vegetation models (Scholze et al.,2006), and earth system models (Ciais et al., 2005; Huntingford et al., 2008). The significant uncertainties associated with modeling tree mortality are reflected in ongoing debates about the magnitude of die-off risk to Amazon rainforests and boreal forests from climate change this century, the potential for dieoffs in forests more generally (Loehle and LeBlanc, 1996; Phillips et al., 2008; Soja et al., 2007), and the degree to which forests worldwide are likely to become a net carbon source or sink (e.g., Kurz et al., 2008b).

\section{Conclusions}

This overview illustrates the complex impacts of drought and heat stress on patterns of tree mortality, and hints at the myriad ways in which changes in drought and/or heat severity, duration, and frequency may lead to gradually increasing background tree mortality rates and even rapid die-off events. Many recent examples of drought and heat-related tree mortality from around the world suggest that no forest type or climate zone is invulnerable to anthropogenic climate change, even in environments not normally considered water-limited. Current observations of forest mortality are insufficient to determine if worldwide trends are emerging in part due to the lack of a reliable, consistent, global monitoring system. Although the effects of climate change cannot be isolated in these studies and clearly episodic forest tree mortality occurs in the absence of climate change, the globally extensive studies identified here are consistent with projections of increased forest mortality and suggest that some forested ecosystems may already be shifting in response to climate.

There are major scientific uncertainties in our understanding of climate-induced tree mortality, particularly regarding the mechanisms that drive mortality, including physiological thresholds of tree death and interactions with biotic agents. Recent advances in the understanding of tree mortality mechanisms suggest that forests could be particularly sensitive to increases in temperature in addition to drought alone, especially in cases where carbon starvation rather than hydraulic failure is the primary mechanism of tree mortality. However, we currently lack the ability to predict mortality and die-off of tree species and forest types based on specific combinations of climatic events and their interactions with biotic stressors and place-specific site conditions. The potential for broad-scale climate-induced tree mortality can be considered a nonlinear "tipping element" in the Earth's climate system (Lenton et al., 2008), because forest die-offs from drought can emerge abruptly at a regional scale when climate exceeds species-specific physiological thresholds, or if climate triggers associated irruptions of insect pests in weakened forests. Such cross-scale mortality processes in forests remain poorly understood.

Collectively, these uncertainties currently prevent reliable determination of actual mortality trends in forests worldwide, and also hinder model projections of future forest mortality in response to climate change. As one consequence, the potential for climate change to trigger widespread forest die-off may be underrepresented in important assessments to date, notably including the latest major IPCC report (2007b). If extensive climate-induced tree mortality occurs, then substantial negative ecological and societal consequences can be expected. Determining the potential for broad-scale, climate-induced tree mortality is therefore a key research priority for ecologists and global change scientists, and is essential for informing and supporting policy decisions and forest management practices.

\section{Acknowledgements}

We thank Rebecca Oertel, Andrew Goumas, Ángeles G. Mayor, Russell Fairfax, and Megan Eberhardt Frank for literature review assistance; Jennifer Shoemaker for graphics support; and Julio Betancourt, Adrian Das, Dan Fagre, Brian Jacobs, Francisco Lloret, Cynthia 
Melcher, Catherine Parks, Tom Veblen, and Connie Woodhouse, and two anonymous reviewers for comments on this paper. Support was provided by the U.S. Geological Survey, Biological Resources Discipline, Global Change Program (CDA); the National Science Foundation and Science Foundation Arizona (AKM); US DOE NICCR DE-FC0206ER64159 and Biosphere 2- Philecology (DDB); and Chinese Special Research Program for Public-Welfare Forestry 2007 BAC03A02 and 200804001 (ZZ). This work is a contribution of the Western Mountain Initiative, a USGS global change research project.
Appendix A

These appendix tables (Tables A1-A6) accompany the continental-scale maps and associated text descriptions, and are the core compilation of documented examples of drought and heat-induced tree mortality. Organized by continent and year of mortality event, concisely listing key information for each documented example, including an identification number allowing easy visual linkage to the continental-scale map locations. 
Table A1

Documented cases of drought and/or heat-induced forest mortality from Africa, 1970-present. ID numbers refer to locations mapped in Fig. 2.

\begin{tabular}{|c|c|c|c|c|c|c|c|c|c|c|}
\hline ID & Location & $\begin{array}{l}\text { Year(s) of } \\
\text { mortality }\end{array}$ & Forest type/mean precip. ${ }^{a}$ & Dominant tree taxa & $\begin{array}{l}\text { Spatial concentration } \\
\text { of mortality within } \\
\text { geographic or } \\
\text { elevational range }\end{array}$ & $\begin{array}{l}\text { Climate anomaly } \\
\text { linked to mortality }\end{array}$ & $\begin{array}{l}\text { Stand/ } \\
\text { population- } \\
\text { level } \\
\text { mortality } \\
(\%)^{\mathrm{b}}\end{array}$ & $\begin{array}{l}\text { Scale of } \\
\text { impact/area } \\
\text { affected }\end{array}$ & $\begin{array}{l}\text { Biotic agents } \\
\text { associated with } \\
\text { mortality? }\end{array}$ & Reference $(s)^{d}$ \\
\hline 1 & Senegal & 1972-1973 & Savanna (300) & $\begin{array}{l}\text { Acacia senegal, Guiera } \\
\text { senegalensis }\end{array}$ & $\begin{array}{l}\text { Middle-lower edges of } \\
\text { elevational range; } \\
\text { arid edge of geographic } \\
\text { range }\end{array}$ & Multi-year drought & 50 & Regional & None & Poupon (1980) \\
\hline 2 & $\begin{array}{l}\text { South Africa } \\
\text { (Northern } \\
\text { Province) }\end{array}$ & 1988-1992 & Savanna (366) & Colophospermum mopane & Patchy within range & Multi-year drought & $\begin{array}{l}\text { 13-87 } \\
\text { (basal area) }\end{array}$ & Not reported & Not reported & $\begin{array}{l}\text { MacGregor and } \\
\text { O'Connor (2002) }\end{array}$ \\
\hline 3 & $\begin{array}{l}\text { Zimbabwe } \\
\text { (Southeast) }\end{array}$ & $\begin{array}{l}\text { 1970-1982, } \\
1991-1992\end{array}$ & Savanna & $\begin{array}{l}\text { Brachystegia glaucescens; } \\
\text { other savanna species }\end{array}$ & Not reported & Multi-year droughts & Not reported & $\begin{array}{l}\text { Subregional; } \\
\sim 500,000 \text { ha } \\
\text { affected }\end{array}$ & $\begin{array}{l}\text { Elephants, } \\
\text { scale insects }\end{array}$ & $\begin{array}{l}\text { Tafangenyasha } \\
(\text { 2001, 1998, 1997) }\end{array}$ \\
\hline 4 & Senegal & $1945-1993$ & $\begin{array}{l}\text { Savanna, deciduous } \\
\text { broadleaf woodland } \\
(240-560)\end{array}$ & $\begin{array}{l}\text { Anacardium occidentale, } \\
\text { Cordyla pinnata, Ficus ingens, } \\
\text { many others }\end{array}$ & $\begin{array}{l}\text { Arid edges of geographic } \\
\text { range }\end{array}$ & Multi-year drought & 23 & Regional & None & Gonzalez (2001) \\
\hline 5 & $\begin{array}{l}\text { South Africa } \\
\text { (Northern } \\
\text { Province) }\end{array}$ & 1991-1993 & $\begin{array}{l}\text { Woodland, deciduous } \\
\text { broadleaf (500-600) }\end{array}$ & $\begin{array}{l}\text { Dichrostachys cinerea, } \\
\text { Pterocarpus angolensis, } \\
\text { Strychnos madagascariensis, } \\
\text { Terminalia sericea, C. mopane, } \\
\text { many others }\end{array}$ & Patchy within range & Multi-year drought & $\begin{array}{l}1-78 \\
\text { (species- } \\
\text { dependent) }\end{array}$ & Not reported & None & Viljoen (1995) \\
\hline 6 & $\begin{array}{l}\text { South Africa } \\
\text { (Northern } \\
\text { Province) }\end{array}$ & 1982-1997 & Savanna $(240-500)$ & $\begin{array}{l}\text { C. mopane, Combretum } \\
\text { apiculatum, Grewia spp., } \\
\text { Ximenia americana }\end{array}$ & Patchy within range & Multi-year drought & 7 & Not reported & None & O'Connor (1999) \\
\hline 7 & $\begin{array}{l}\text { Uganda } \\
\text { (Western) }\end{array}$ & 1999 & Tropical Rainforest (1492) & Uvariopsis spp., Celtis spp. & Not reported & Seasonal drought & 19 & Not reported & Not reported & Lwanga (2003) \\
\hline 8 & $\begin{array}{l}\text { Namibia, } \\
\text { South Africa }\end{array}$ & 1904-2002 & Savanna (100-200) & Aloe dichotoma & $\begin{array}{l}\text { Arid edge of geographic } \\
\text { range }\end{array}$ & $\begin{array}{l}\text { Multi-year drought, } \\
\text { high temperatures }\end{array}$ & $2-71$ & Subregional & None & Foden et al. (2007) \\
\hline 9 & Algeria & $2000-2008$ & Med. conifer (348-356) & Cedrus atlantica & $\begin{array}{l}\text { Arid edge of geographic } \\
\text { range }\end{array}$ & Multi-year drought & $40-80$ & Subregional & Insects & $\begin{array}{l}\text { Bentouati (2008); } \\
\text { Bentouati and } \\
\text { Bariteau (2006); } \\
\text { Chenchouni } \\
\text { et al. (2008) }\end{array}$ \\
\hline 10 & Morocco & 2002-2008 & $\begin{array}{l}\text { Med. montane conifer } \\
(300-600)\end{array}$ & Cedrus atlantica & $\begin{array}{l}\text { Arid edge of geographic } \\
\text { range }\end{array}$ & Multi-year drought & $10-40$ & Subregional & Not reported & $\begin{array}{l}\text { El Abidine (2003); } \\
\text { Adil (2008) }\end{array}$ \\
\hline
\end{tabular}

a Mediterranean forest types are abbreviated as Med. in this column. Annual precipitation is in $\mathrm{mm} / \mathrm{yr}$ in parentheses if reported.

b Severity of mortality is reported at the stand or population level as percentage of dead trees (depending on study design), unless otherwise noted in the entry. Other common units are annual mortality rate during drought (\%/ year), percent dead basal area, and dead wood volume in meters ${ }^{3}$.

${ }^{c}$ If biotic agents are thought to have played a primary role in tree mortality, this is noted in bold type. If biotic agents were involved in mortality but their role was not evaluated or is secondary to climate, the agents are simply listed.

${ }_{\mathrm{d}}^{\mathrm{C}}$ Citations from which reported mortality data is derived are written in bold type. Other citations provide corroborating or secondary evidence. If there are multiple citations without no bold type, reported data reflects numbers compiled from all citations. 
Table A2

\begin{tabular}{|c|c|c|c|c|c|c|c|c|c|c|}
\hline ID & Location & $\begin{array}{l}\text { Year(s) of } \\
\text { mortality }\end{array}$ & $\begin{array}{l}\text { Forest type/mean } \\
\text { precip. }^{\text {}}\end{array}$ & Dominant tree taxa & $\begin{array}{l}\text { Spatial concentration } \\
\text { of mortality within } \\
\text { geographic or } \\
\text { elevational range }\end{array}$ & $\begin{array}{l}\text { Climate } \\
\text { anomaly } \\
\text { linked to } \\
\text { mortality }\end{array}$ & $\begin{array}{l}\text { Stand/ } \\
\text { population- } \\
\text { level mortality } \\
(\%)^{\mathrm{b}}\end{array}$ & $\begin{array}{l}\text { Scale of } \\
\text { impact/ } \\
\text { area affected }\end{array}$ & $\begin{array}{l}\text { Biotic agents } \\
\text { associated } \\
\text { with } \\
\text { mortality? }^{c}\end{array}$ & Reference $(s)^{d}$ \\
\hline 1 & Sri Lanka & $1976-1980$ & $\begin{array}{l}\text { Montane tropical } \\
\text { rainforest }\end{array}$ & $\begin{array}{l}\text { Calophyllurn spp., } \\
\text { Syzygium spp. }\end{array}$ & $\begin{array}{l}\text { Upper-mid } \\
\text { elevational range }\end{array}$ & $\begin{array}{l}\text { Seasonal } \\
\text { drought }\end{array}$ & $50-100$ & Not reported & Not reported & Werner (1988) \\
\hline 2 & $\begin{array}{l}\text { Malaysia } \\
\text { (Borneo) }\end{array}$ & 1982-1983 & $\begin{array}{l}\text { Tropical rainforest } \\
(\sim 2000)\end{array}$ & $\begin{array}{l}\text { Dipterocarpus spp., } \\
\text { Shorea spp. }\end{array}$ & Not reported & $\begin{array}{l}\text { Seasonal } \\
\text { drought }\end{array}$ & $12-28$ & Not reported & Not reported & $\begin{array}{l}\text { Woods (1989); Becker et al. } \\
\text { (1998); Leighton and } \\
\text { Wirawan (1986) }\end{array}$ \\
\hline 3 & India (Gujarat) & 1987 & Tropical dry deciduous & $\begin{array}{l}\text { Acacia senegal, } \\
\text { Holarrhena } \\
\text { antidysenterica, } \\
\text { Helicteres isora, } \\
\text { Terminalia crenulata, } \\
\text { others }\end{array}$ & Not reported & $\begin{array}{l}\text { Seasonal or } \\
\text { single-year } \\
\text { drought }\end{array}$ & $\begin{array}{l}\text { 37-82 (species- } \\
\text { dependent) }\end{array}$ & $\begin{array}{l}\sim 141,000 \text { ha } \\
\text { affected }\end{array}$ & $\begin{array}{l}\text { Ungulates } \\
\text { (Cervus unicolor) }\end{array}$ & Khan et al. (1994) \\
\hline 4 & $\begin{array}{l}\text { Russia (Far } \\
\text { East) }\end{array}$ & 1987-1988 & Montane mixed conifer & $\begin{array}{l}\text { Picea jezoensis, Abies } \\
\text { nephrolepis }\end{array}$ & $\begin{array}{l}\text { Mountain slopes } \\
\text { and plateaus, } \\
\text { variable aspects }\end{array}$ & Drought & $\begin{array}{l}14 \mathrm{M} \mathrm{m}^{3} \text { timber } \\
\text { lost }\end{array}$ & $\begin{array}{l}\sim 165,000 \text { ha } \\
\text { affected }\end{array}$ & Fungi & Man'ko and Gladkova (2001) \\
\hline 5 & $\begin{array}{l}\text { Saudi Arabia } \\
\text { and Oman }\end{array}$ & Early 1990 s & Woodland (559) & $\begin{array}{l}\text { Juniperus procera, } \\
\text { J. excelsa }\end{array}$ & $\begin{array}{l}\text { Lower edges of } \\
\text { elevational range }\end{array}$ & $\begin{array}{l}\text { Possibly } \\
\text { drought }\end{array}$ & 30 (J. excelsa) & $\begin{array}{l}\text { Landscape- } \\
\text { subregional }\end{array}$ & None & $\begin{array}{l}\text { Fisher and Gardner (1995); Fisher } \\
\text { (1997); Gardner and Fisher (1996) }\end{array}$ \\
\hline 6 & $\begin{array}{l}\text { Indonesia } \\
\text { (Sumatra) }\end{array}$ & 1997-1998 & Tropical rainforest & Not reported & Not reported & $\begin{array}{l}\text { Seasonal } \\
\text { drought }\end{array}$ & 9.8 & Not reported & Not reported & Kinnaird and O'Brien, 1998 \\
\hline 7 & $\begin{array}{l}\text { Indonesia and } \\
\text { Malaysia } \\
\text { (Borneo) }\end{array}$ & 1997-1998 & $\begin{array}{l}\text { Tropical rainforest } \\
(\sim 2100-3000)\end{array}$ & $\begin{array}{l}\text { Dipterocarpus spp., } \\
\text { Lauraceae }\end{array}$ & Not reported & $\begin{array}{l}\text { Seasonal } \\
\text { drought }\end{array}$ & $0.6-26.3$ & Not reported & Not reported & $\begin{array}{l}\text { van Nieuwstadt and Sheil (2005); } \\
\text { Potts (2003); Aiba and Kitayama } \\
\text { (2002); Slik (2004) }\end{array}$ \\
\hline 8 & $\begin{array}{l}\text { Indonesia } \\
\text { (Borneo) }\end{array}$ & 1997-1998 & $\begin{array}{l}\text { Tropical lowland } \\
\text { swamp (2800) }\end{array}$ & $\begin{array}{l}\text { Anacardiacea, } \\
\text { Dipterocarpaceae, } \\
\text { Sapotaceae, Rutaceae }\end{array}$ & Not reported & $\begin{array}{l}\text { Seasonal } \\
\text { drought }\end{array}$ & $4.2-6.1$ & Not reported & Not reported & Nishimua et al. (2007) \\
\hline 9 & $\begin{array}{l}\text { Malaysia } \\
\text { (Borneoo) }\end{array}$ & 1997-1998 & $\begin{array}{l}\text { Tropical rainforest } \\
(\sim 2700)\end{array}$ & $\begin{array}{l}\text { Dipterocarpaceae, } \\
\text { Euphorbiaceae, } \\
\text { Burseraceae, } \\
\text { Myristicaceae }\end{array}$ & Not reported & $\begin{array}{l}\text { Seasonal } \\
\text { drought }\end{array}$ & $4.3-6.4$ & Not reported & Not reported & $\begin{array}{l}\text { Nakagawa et al. (2000); } \\
\text { Lingenfelder and } \\
\text { Newbery (2009) }\end{array}$ \\
\hline 10 & $\begin{array}{l}\text { China (Shanxi, } \\
\text { Hebei, Henan) }\end{array}$ & 1998-2001 & $\begin{array}{l}\text { Temperate coniferous } \\
\text { plantation }\end{array}$ & Pinus tabulaeformia & Not reported & $\begin{array}{l}\text { Seasonal } \\
\text { drought }\end{array}$ & $\sim 30$ & $\begin{array}{l}\text { Subregional; } \\
500,000 \text { ha } \\
\text { affected }\end{array}$ & $\begin{array}{l}\text { Bark beetles } \\
\text { (Dendroctonus } \\
\text { valens) }\end{array}$ & Wang et al. (2007) \\
\hline 11 & $\begin{array}{l}\text { China } \\
\text { (Yunnan) }\end{array}$ & $\begin{array}{l}\text { 1986-1988; } \\
\text { 1998-2000; } \\
\text { 2003-2005 }\end{array}$ & $\begin{array}{l}\text { Subtropical coniferous } \\
\text { plantation }\end{array}$ & Pinus yunnanensis & Not reported & $\begin{array}{l}\text { Seasonal } \\
\text { drought }\end{array}$ & $\begin{array}{l}\text { Varied in } \\
\text { different } \\
\text { plantations }\end{array}$ & $\begin{array}{l}\text { Landscape; } 26,700- \\
113,000 \text { ha affected }\end{array}$ & $\begin{array}{l}\text { Bark beetles } \\
\text { (Tomicus } \\
\text { yunnanensis, } \\
\text { T. minor) }\end{array}$ & Li (2003) \\
\hline 12 & $\begin{array}{l}\text { Turkey } \\
\text { (Central } \\
\text { Anatolia) }\end{array}$ & 2002-2007 & $\begin{array}{l}\text { Temperate conifer and } \\
\text { mixed }(400-600)\end{array}$ & $\begin{array}{l}\text { Qercus spp., Juniper } \\
\text { spp., Pinus nigra, } \\
\text { P. sylvestris, } \\
\text { Abies cilicicia }\end{array}$ & $\begin{array}{l}\text { Southern edge of } \\
\text { geographic range } \\
\text { for } P \text {. sylvestris }\end{array}$ & Drought & Not reported & Not reported & Insects & Semerci et al. (2008) \\
\hline 13 & South Korea & 2003-2008 & $\begin{array}{l}\text { Temperate montane } \\
\text { mixed }(1400-2000)\end{array}$ & Abies koreana & Not reported & $\begin{array}{l}\text { Warm winters/ } \\
\text { springs, possibly } \\
\text { drought }\end{array}$ & $20-50$ & Landscape & Not reported & $\begin{array}{l}\text { Lim et al. (2008); } \\
\text { Woo et al. (2007) }\end{array}$ \\
\hline 14 & Russia & 2005-2008 & Boreal and temperate & Picea spp., Pinus spp. & $\begin{array}{l}\text { Southern portions of } \\
\text { Russian forest zones }\end{array}$ & Drought & Not reported & $\begin{array}{l}>400,000 \text { ha } \\
\text { across the nation }\end{array}$ & Not reported & Ermolenko (2008) \\
\hline
\end{tabular}

Footnotes as in Table A1. 
Table A3

Documented cases of drought and/or heat-induced forest mortality from Australasia, 1970-present. ID numbers refer to locations mapped in Fig. 5.

\begin{tabular}{|c|c|c|c|c|c|c|c|c|c|c|}
\hline ID & Location & $\begin{array}{l}\text { Year(s) of } \\
\text { mortality }\end{array}$ & $\begin{array}{l}\text { Forest type/ } \\
\text { mean precip. }{ }^{a}\end{array}$ & $\begin{array}{l}\text { Dominant tree } \\
\text { taxa }\end{array}$ & $\begin{array}{l}\text { Spatial concentration } \\
\text { of mortality within } \\
\text { geographic or } \\
\text { elevational range }\end{array}$ & $\begin{array}{l}\text { Climate } \\
\text { anomaly linked } \\
\text { to mortality }\end{array}$ & $\begin{array}{l}\text { Stand/ } \\
\text { population- } \\
\text { level } \\
\text { mortality (\%) }\end{array}$ & $\begin{array}{l}\text { Scale of impact/ } \\
\text { area affected }\end{array}$ & $\begin{array}{l}\text { Biotic agents associated } \\
\text { with mortality? }\end{array}$ & Reference(s) $)^{\mathrm{d}}$ \\
\hline 1 & $\begin{array}{l}\text { New Zealand } \\
\text { (West Coast) }\end{array}$ & $1978-1980$ & $\begin{array}{l}\text { Montane } \\
\text { broadleaf }\end{array}$ & Nothofagus fusca & Not reported & Spring droughts & 75 & $\begin{array}{l}\text { Landscape; } \\
\sim 5000 \text { ha } \\
\text { affected }\end{array}$ & $\begin{array}{l}\text { Beech scale (Inglisia fagi); } \\
\text { Fungi (Hypocrella duplex); } \\
\text { Wood borer (Platypus spp., } \\
\text { Psepholax spp.) }\end{array}$ & $\begin{array}{l}\text { Hosking and Kershaw } \\
\text { (1985) }\end{array}$ \\
\hline 2 & $\begin{array}{l}\text { New Zealand } \\
\text { (Hawkes Bay) }\end{array}$ & 1984-1987 & $\begin{array}{l}\text { Montane } \\
\text { broadleaf }\end{array}$ & Nothofagus solandri & Not reported & Spring droughts & $24-52$ & Not reported & $\begin{array}{l}\text { Leafminer (Neomycta } \\
\text { pulicaris); Fungi } \\
\text { (Nodulisporium spp.) }\end{array}$ & $\begin{array}{l}\text { Hosking and Hutcheson } \\
\text { (1988) }\end{array}$ \\
\hline 3 & $\begin{array}{l}\text { Australia } \\
\text { (Queensland) }\end{array}$ & 1992-1996 & $\begin{array}{l}\text { Tropical savanna } \\
(480-2600)\end{array}$ & $\begin{array}{l}\text { Eucalyptus spp., } \\
\text { Corymbia spp. }\end{array}$ & $\begin{array}{l}\text { Patchy within } \\
\text { ranges }\end{array}$ & Multi-year drought & 29 (basal area) & $\begin{array}{l}\text { Regional; } \\
\sim 5.5 \mathrm{M} \mathrm{ha} \\
\text { affected }\end{array}$ & None & $\begin{array}{l}\text { Fensham and Holman } \\
\text { (1999); Fensham (1998) } \\
\text { Rice et al. (2004) }\end{array}$ \\
\hline 4 & $\begin{array}{l}\text { Australia } \\
\text { (Queensland) }\end{array}$ & 1990-2002 & $\begin{array}{l}\text { Tropical savanna } \\
(500-850)\end{array}$ & $\begin{array}{l}\text { Eucalyptus spp., } \\
\text { Corymbia spp. }\end{array}$ & $\begin{array}{l}\text { Patchy within } \\
\text { ranges }\end{array}$ & Multi-year drought & $\begin{array}{l}78 \text { stand level; } \\
17.7 \text { across } \\
\text { region }\end{array}$ & $\begin{array}{l}\text { Regional; } \\
\sim 5.5 \mathrm{M} \text { ha } \\
\text { affected }\end{array}$ & None & $\begin{array}{l}\text { Fensham et al. } \\
(2003,2009)\end{array}$ \\
\hline 5 & $\begin{array}{l}\text { Australia } \\
\text { (Queensland) }\end{array}$ & 2004 & $\begin{array}{l}\text { Tropical savanna } \\
(500-850)\end{array}$ & $\begin{array}{l}\text { Eucalyptus spp., } \\
\text { Corymbia spp. }\end{array}$ & $\begin{array}{l}\text { Patchy within } \\
\text { ranges }\end{array}$ & Multi-year drought & $\begin{array}{l}15.0 \text { (basal area; } \\
\text { unpublished data) }\end{array}$ & Not reported & None & $\begin{array}{l}\text { Fensham and Fairfax } \\
(2007)\end{array}$ \\
\hline 6 & $\begin{array}{l}\text { Australia } \\
\text { (Queensland) }\end{array}$ & 2005 & $\begin{array}{l}\text { Tropical savanna } \\
(500-850)\end{array}$ & Acacia spp. & Widespread & Multi-year drought & Not recorded & $\begin{array}{l}\sim 600 \mathrm{ha} \\
\text { affected }\end{array}$ & None & $\begin{array}{l}\text { Fensham and Fairfax } \\
(2005)\end{array}$ \\
\hline
\end{tabular}

Footnotes are as given in Table $\mathrm{A} 1$.

Table A4

Documented cases of drought and/or heat-induced forest mortality from Europe, 1970-present. ID numbers refer to locations mapped in Fig. 6.

\begin{tabular}{|c|c|c|c|c|c|c|c|c|c|c|}
\hline ID & Location & $\begin{array}{l}\text { Year(s) of } \\
\text { mortality }\end{array}$ & $\begin{array}{l}\text { Forest type/ } \\
\text { mean precip. }\end{array}$ & $\begin{array}{l}\text { Dominant tree } \\
\text { taxa }\end{array}$ & $\begin{array}{l}\text { Spatial concentration } \\
\text { of mortality within } \\
\text { geographic or } \\
\text { elevational range }\end{array}$ & $\begin{array}{l}\text { Climate } \\
\text { anomaly linked } \\
\text { to mortality }\end{array}$ & $\begin{array}{l}\text { Stand/ } \\
\text { population- } \\
\text { level } \\
\text { mortality }(\%)^{\mathrm{b}}\end{array}$ & $\begin{array}{l}\text { Scale of impact/ } \\
\text { area affected }\end{array}$ & $\begin{array}{l}\text { Biotic agents associated } \\
\text { with mortality? }^{\mathrm{c}}\end{array}$ & Reference $(s)^{d}$ \\
\hline 1 & $\begin{array}{l}\text { Switzerland } \\
\text { (Valais) }\end{array}$ & 1960-1976 & $\begin{array}{l}\text { Temperate } \\
\text { conifer (572) }\end{array}$ & Pinus sylvestris & $\begin{array}{l}\text { Lower/southern edges } \\
\text { of ranges }\end{array}$ & $\begin{array}{l}\text { Multi-year } \\
\text { drought }\end{array}$ & $5-100$ & $\begin{array}{l}\text { Landscape- } \\
\text { subregional }\end{array}$ & Not reported & Kienast et al. (1981) \\
\hline 2 & $\begin{array}{l}\text { Europe } \\
\text { (Western, } \\
\text { Central) }\end{array}$ & 1970-1985 & $\begin{array}{l}\text { Temperate } \\
\text { conifer and } \\
\text { broadleaf } \\
(600-1500)\end{array}$ & $\begin{array}{l}\text { Abies spp., Picea } \\
\text { spp., Pinus spp., } \\
\text { Fagus sylvatica }\end{array}$ & $\begin{array}{l}\text { Lower edges of } \\
\text { elevation range }\end{array}$ & $\begin{array}{l}\text { Repeated } \\
\text { droughts }\end{array}$ & $1-20$ & $\begin{array}{l}\text { Regional; } \\
\text { patchy across } \\
<1 \mathrm{M} \mathrm{ha}\end{array}$ & $\begin{array}{l}\text { Bark beetles (Scolytus, } \\
\text { Ips, Pityogenes, Tomicus, } \\
\text { Dendrochtonus, } \\
\text { Pytiokteines); Fungi }\end{array}$ & Schutt and Cowling (1985) \\
\hline 3 & France & 1980-1985 & $\begin{array}{l}\text { Temperate } \\
\text { broadleaf } \\
(650-850)\end{array}$ & $\begin{array}{l}\text { Quercus spp.. } \\
\text { mainly Q. robur }\end{array}$ & Patchy across ranges & $\begin{array}{l}\text { Seasonal or } \\
\text { single-year } \\
\text { drought }\end{array}$ & $10-50$ & $\begin{array}{l}\text { Subregional; } \\
\text { patchy across } \\
\sim 500,000 \text { ha }\end{array}$ & $\begin{array}{l}\text { Fungi; bark beetles } \\
\text { (Agriles, Scolytus) }\end{array}$ & $\begin{array}{l}\text { Nageleisen (1994); } \\
\text { Nageleisen et al. (1991); } \\
\text { Delatour (1983) }\end{array}$ \\
\hline 4 & Poland & 1979-1987 & $\begin{array}{l}\text { Temperate } \\
\text { broadleaf } \\
(500-550)\end{array}$ & Quercus robur & Not reported & $\begin{array}{l}\text { Seasonal } \\
\text { drought }\end{array}$ & $\begin{array}{l}111,000 \mathrm{~m}^{3} \\
\text { timber lost }\end{array}$ & Landscape & $\begin{array}{l}\text { Moths (Tortrix viridiana); } \\
\text { pathogens } \\
\text { (Ophiostoma spp.) }\end{array}$ & $\begin{array}{l}\text { Siwecki and Ufnalksi } \\
\text { (1998) }\end{array}$ \\
\hline 5 & Greece & 1987-1989 & $\begin{array}{l}\text { Mediterranean } \\
\text { mixed conifer } \\
(1622)\end{array}$ & $\begin{array}{l}\text { Abies alba Mill. } \\
\times \text { A. cephalonica } \\
\text { Loud. }\end{array}$ & $\begin{array}{l}\text { Middle of elevation } \\
\text { ranges }\end{array}$ & $\begin{array}{l}\text { Multi-year } \\
\text { drought }\end{array}$ & $\begin{array}{l}1.8 / \mathrm{yr} \text { in } \\
\text { drought } \\
\text { years }\end{array}$ & $\begin{array}{l}\text { Landscape- } \\
\text { subregional }\end{array}$ & $\begin{array}{l}\text { Bark beetles and other } \\
\text { insects }\end{array}$ & $\begin{array}{l}\text { Markalas (1992); Kailidis } \\
\text { and Markalas (1990) }\end{array}$ \\
\hline 6 & $\begin{array}{l}\text { Italy (South } \\
\text { Tyrol) }\end{array}$ & 1992 & $\begin{array}{l}\text { Temperate } \\
\text { mixed conifer } \\
(650)\end{array}$ & Pinus sylvestris & $\begin{array}{l}\text { Lower/southern edges } \\
\text { of ranges }\end{array}$ & $\begin{array}{l}\text { Multi-year } \\
\text { drought }\end{array}$ & Not reported & $\begin{array}{l}\text { Landscape- } \\
\text { subregional }\end{array}$ & Various insects & Minerbi (1993) \\
\hline
\end{tabular}




\begin{tabular}{|c|c|c|c|c|c|c|c|c|c|c|}
\hline 7 & $\begin{array}{l}\text { Austria (Lower } \\
\text { Austria) }\end{array}$ & 1990-1996 & $\begin{array}{l}\text { Temperate mixed } \\
\text { conifer }(\sim 650)\end{array}$ & $\begin{array}{l}\text { Pinus sylvestris, } \\
\text { Pinus nigra }\end{array}$ & $\begin{array}{l}\text { Lower edge of } \\
\text { elevational range }\end{array}$ & $\begin{array}{l}\text { Seasonal } \\
\text { droughts }\end{array}$ & $27.6-49.2$ & Stand-landscape & Various insects & Cech and Tomiczek (1996) \\
\hline 8 & Austria (Tyrol) & 1991-1997 & $\begin{array}{l}\text { Temperate mixed } \\
\text { conifer }(\sim 840)\end{array}$ & Pinus sylvestris & $\begin{array}{l}\text { Lower edge of } \\
\text { elevational range }\end{array}$ & $\begin{array}{l}\text { Seasonal } \\
\text { droughts }\end{array}$ & $10.0-70.0$ & Landscape & Various insects & Cech and Perny (2000) \\
\hline 9 & Italy (Aosta) & 1985-1998 & $\begin{array}{l}\text { Temperate mixed } \\
\text { conifer and } \\
\text { broadleaf }(\sim 550)\end{array}$ & Pinus sylvestris & $\begin{array}{l}\text { Lower/southern } \\
\text { edges of ranges }\end{array}$ & $\begin{array}{l}\text { Multi-year } \\
\text { drought }\end{array}$ & Not reported & $\begin{array}{l}\text { Landscape- } \\
\text { subregional }\end{array}$ & $\begin{array}{l}\text { Fungi (Armillaria spp.); } \\
\text { wood borers }\end{array}$ & $\begin{array}{l}\text { Vertui and Tagliaferro } \\
\text { (1998) }\end{array}$ \\
\hline 10 & $\begin{array}{l}\text { Spain } \\
\text { (Northeast, } \\
\text { Central, South) }\end{array}$ & 1994, 1998 & $\begin{array}{l}\text { Mediterranean } \\
\text { mixed conifer } \\
\text { and broadleaf } \\
(537-605)\end{array}$ & $\begin{array}{l}\text { Quercus spp., } \\
\text { Pinus spp., } \\
\text { Juniperus spp. }\end{array}$ & $\begin{array}{l}\text { Patchy within } \\
\text { elevational range; } \\
\text { southern edge of } \\
\text { geographic range } \\
\text { (P. sylvestris) }\end{array}$ & $\begin{array}{l}\text { Multi-year } \\
\text { drought, } \\
\text { recurrent } \\
\text { summer } \\
\text { droughts }\end{array}$ & $\begin{array}{l}0.0-19.4 \\
\text { (species- } \\
\text { dependent) }\end{array}$ & $\begin{array}{l}\text { Landscape- } \\
\text { subregional }\end{array}$ & Not reported & $\begin{array}{l}\text { Peñuelas et al. (2001); } \\
\text { Lloret and Siscart (1995); } \\
\text { Lloret et al. (2004); } \\
\text { Martinez-Vilalta and } \\
\text { Piñol (2002) }\end{array}$ \\
\hline 11 & $\begin{array}{l}\text { France } \\
\text { (Ardennes, } \\
\text { Vosges) }\end{array}$ & 1998 & $\begin{array}{l}\text { Montane mixed } \\
\text { conifer and } \\
\text { broadleaf } \\
(800-1200)\end{array}$ & Fagus sylvatica & Middle of ranges & $\begin{array}{l}\text { Deep frost } \\
\text { after an } \\
\text { abnomally hot } \\
\text { period }\end{array}$ & $5-30$ & $\begin{array}{l}\text { Subregional; } \\
\text { patchy across } \\
\sim 200,000 \text { ha }\end{array}$ & None & $\begin{array}{l}\text { French Forest Health } \\
\text { Department (1998-1999) }\end{array}$ \\
\hline 12 & Norway & $1992-2000$ & $\begin{array}{l}\text { Temperate } \\
\text { conifer }\end{array}$ & Picea abies & Patchy across ranges & $\begin{array}{l}\text { Multi-year } \\
\text { summer } \\
\text { droughts, high } \\
\text { summer } \\
\text { temperatures }\end{array}$ & $2-6.6$ & $\begin{array}{l}\text { Landscape- } \\
\text { subregional }\end{array}$ & $\begin{array}{c}\text { Bark beetles } \\
\text { (Polygraphus } \\
\text { poligraphus) }\end{array}$ & Solberg (2004) \\
\hline 13 & $\begin{array}{l}\text { Greece } \\
\text { (Samos) }\end{array}$ & 2000 & $\begin{array}{l}\text { Mediterranean } \\
\text { mixed conifer } \\
(\sim 700-800)\end{array}$ & Pinus brutia & $\begin{array}{l}\text { Lower edge of } \\
\text { elevational range }\end{array}$ & $\begin{array}{l}\text { Multi-year } \\
\text { drought }\end{array}$ & Not reported & Not reported & Not reported & $\begin{array}{l}\text { Körner et al. (2005); } \\
\text { Sarris et al. (2007) }\end{array}$ \\
\hline 14 & Austria (Tyrol) & 2001 & $\begin{array}{l}\text { Temperate } \\
\text { mixed conifer } \\
\text { (710) }\end{array}$ & Pinus sylvestris & $\begin{array}{l}\text { Lower edge of } \\
\text { elevational range }\end{array}$ & $\begin{array}{l}\text { Seasonal } \\
\text { droughts }\end{array}$ & Not reported & $\begin{array}{l}\text { Landscape- } \\
\text { subregional }\end{array}$ & Not reported & Oberhuber (2001) \\
\hline 15 & $\begin{array}{l}\text { Greece } \\
\text { (South, } \\
\text { Central) }\end{array}$ & 2000-2002 & $\begin{array}{l}\text { Mediterranean } \\
\text { mixed conifer } \\
(\sim 700-1100)\end{array}$ & $\begin{array}{l}\text { Abies } \\
\text { cephalonica }\end{array}$ & Not reported & $\begin{array}{l}\text { Multi-year } \\
\text { drought }\end{array}$ & $\begin{array}{l}5-10 / \text { yr in } \\
\text { drought years } \\
\text { vs. } 0.17-0.50 / \\
\text { yr in non- } \\
\text { drought years }\end{array}$ & Landscape & $\begin{array}{l}\text { Primary role, bark } \\
\text { beetles (Phaenops } \\
\text { knoteki, Pityokteines } \\
\text { spinidens) mistletoe }\end{array}$ & $\begin{array}{l}\text { Tsopelas et al. (2004); } \\
\text { Raftoyannis et al. (2008) }\end{array}$ \\
\hline 16 & Switzerland & 2003 & $\begin{array}{l}\text { Temperate } \\
\text { conifer and } \\
\text { broadleaf }\end{array}$ & Picea abies & Not reported & $\begin{array}{l}\text { Drought, high } \\
\text { temperatures }\end{array}$ & $\begin{array}{l}\sim 2.0 \mathrm{M} \mathrm{m}^{3} \\
\text { timber lost }\end{array}$ & $\begin{array}{l}\text { Landscape- } \\
\text { subregional }\end{array}$ & $\begin{array}{l}\text { Bark beetles } \\
\text { (Ips typographus) }\end{array}$ & Forster et al. (2008) \\
\hline 17 & $\begin{array}{l}\text { Switzerland } \\
\text { (Valais) }\end{array}$ & $\begin{array}{l}1973-1976 \\
1987-1993 \\
1996-2000 \\
2000-2004\end{array}$ & $\begin{array}{l}\text { Temperate } \\
\text { mixed conifer } \\
\text { and broadleaf } \\
(500-600)\end{array}$ & Pinus sylvestris & $\begin{array}{l}\text { Lower/southern } \\
\text { edges of ranges }\end{array}$ & $\begin{array}{l}\text { Seasonal and } \\
\text { multi-year } \\
\text { droughts, high } \\
\text { temperatures }\end{array}$ & $7-59$ & $\begin{array}{l}\text { Landscape- } \\
\text { subregional }\end{array}$ & $\begin{array}{l}\text { Primary role, bark } \\
\text { beetles (Phaenops } \\
\text { cyanea, Ips acuminatus); } \\
\text { nematodes; mistletoe }\end{array}$ & $\begin{array}{l}\text { Wermelinger et al. (2008); } \\
\text { Dobbertin et al. (2007); } \\
\text { Bigler et al. (2006); } \\
\text { Dobbertin and Rigling } \\
\text { (2006); Rigling et al. (2006); } \\
\text { Dobbertin et al. (2005); } \\
\text { Rigling and Cherubini (1999) }\end{array}$ \\
\hline 18 & $\begin{array}{l}\text { Germany } \\
\text { (Baden- } \\
\text { Württemberg) }\end{array}$ & $2003-2006$ & $\begin{array}{l}\text { Temperate } \\
\text { broadleaf }\end{array}$ & Fagus sylvatica & Not reported & $\begin{array}{l}\text { Drought, high } \\
\text { temperatures }\end{array}$ & $\begin{array}{c}\sim 98,000 \mathrm{~m}^{3} \\
\text { timber lost }\end{array}$ & $\begin{array}{l}\text { Landscape- } \\
\text { subregional }\end{array}$ & $\begin{array}{l}\text { Bark, ambrosia beetles } \\
\text { (Taphrorychus bicolor, } \\
\text { Trypodendron domesticum); } \\
\text { wood borer }\end{array}$ & Petercord (2008) \\
\hline 19 & Spain & 2004-2006 & $\begin{array}{l}\text { Temperate conifer } \\
\text { plantations }\end{array}$ & $\begin{array}{l}\text { Pinus sylvestris, } \\
\text { Pinus nigra }\end{array}$ & Not reported & $\begin{array}{l}\text { Multi-year } \\
\text { drought }\end{array}$ & Not reported & $\begin{array}{l}\text { Patchy across } \\
13,404 \text { ha }\end{array}$ & Not reported & $\begin{array}{l}\text { Navarro-Cerrillo et al. } \\
\text { (2007) }\end{array}$ \\
\hline 20 & $\begin{array}{l}\text { Russia } \\
\text { (Northwest) }\end{array}$ & $2004-2006$ & Boreal conifer & Picea obovata & Patchy & $\begin{array}{l}\text { Drought, high } \\
\text { temperatures }\end{array}$ & $\begin{array}{l}208 \mathrm{M} \mathrm{m}^{3} \\
\text { timber lost }\end{array}$ & $\begin{array}{l}\sim 1.9 \mathrm{M} \mathrm{ha} \\
\text { affected }\end{array}$ & $\begin{array}{l}\text { Bark beetles } \\
\text { (Ips typographus), fungi }\end{array}$ & $\begin{array}{l}\text { Krotov (2007); Tsvetkov } \\
\text { and Tsvetkov (2007); Chuprov } \\
\text { (2007); Shtrakhov (2008); } \\
\text { Kauhanen et al. (2008) }\end{array}$ \\
\hline
\end{tabular}




\begin{tabular}{|c|c|c|c|c|c|c|c|c|c|c|}
\hline ID & Location & $\begin{array}{l}\text { Year(s) of } \\
\text { mortality }\end{array}$ & $\begin{array}{l}\text { Forest type/ } \\
\text { mean precip. }{ }^{\mathrm{a}}\end{array}$ & $\begin{array}{l}\text { Dominant tree } \\
\text { taxa }\end{array}$ & $\begin{array}{l}\text { Spatial concentration } \\
\text { of mortality within } \\
\text { geographic or } \\
\text { elevational range }\end{array}$ & $\begin{array}{l}\text { Climate } \\
\text { anomaly linked } \\
\text { to mortality }\end{array}$ & $\begin{array}{l}\text { Stand/ } \\
\text { population- } \\
\text { level } \\
\text { mortality (\%) }\end{array}$ & $\begin{array}{l}\text { Scale of impact/ } \\
\text { area affected }\end{array}$ & $\begin{array}{l}\text { Biotic agents associated } \\
\text { with mortality? }^{\mathrm{c}}\end{array}$ & Reference $(s)^{d}$ \\
\hline 21 & $\begin{array}{l}\text { Switzerland } \\
\text { (Grisons) }\end{array}$ & 2003-2007 & $\begin{array}{l}\text { Temperate mixed } \\
\text { conifer }(750)\end{array}$ & Pinus sylvestris & $\begin{array}{l}\text { Lower edge of } \\
\text { elevational range }\end{array}$ & $\begin{array}{l}\text { Drought, high } \\
\text { temperatures }\end{array}$ & $6.3-16.0$ & $\begin{array}{l}\text { Landscape- } \\
\text { subregional }\end{array}$ & Not reported & Schilli et al. (in press) \\
\hline 22 & $\begin{array}{l}\text { France } \\
\text { (Provence, } \\
\text { Southern Alps) }\end{array}$ & 2003-2008 & $\begin{array}{l}\text { Mediterranean } \\
\text { conifer } \\
(750-950)\end{array}$ & Pinus sylvestris & $\begin{array}{l}\text { Lower/southern edges } \\
\text { of ranges }\end{array}$ & $\begin{array}{l}\text { Multi-year } \\
\text { drought, high } \\
\text { temperatures }\end{array}$ & $20-80$ & $\begin{array}{l}\text { Subregional; } \\
\text { patchy across } \\
\sim 100,000 \text { ha }\end{array}$ & $\begin{array}{l}\text { Bark beetles } \\
\text { (Tomicus, Ips, Pissodes) }\end{array}$ & $\begin{array}{l}\text { Vennetier et al. (2007); } \\
\text { Thabeet et al. (2009) }\end{array}$ \\
\hline 23 & France & 2003-2008 & $\begin{array}{l}\text { Temperate } \\
\text { mixed conifer } \\
\text { and broadleaf } \\
(650-1100)\end{array}$ & $\begin{array}{l}\text { Quercus spp. } \\
\text { Fagus sylvatica, } \\
\text { Abies spp., } \\
\text { Picea abies, } \\
\text { Pinus spp. }\end{array}$ & $\begin{array}{l}\text { Lower and middle of } \\
\text { elevational range }\end{array}$ & $\begin{array}{l}\text { Spring and } \\
\text { summer } \\
\text { drought, } \\
\text { scorching heat }\end{array}$ & $1-3 / \mathrm{yr}$ & Regional & Bark beetles; fungi & $\begin{array}{l}\text { Breda et al. (2006); } \\
\text { Landmann et al. (2006); } \\
\text { Rouault et al. (2006); } \\
\text { French Forest Health } \\
\text { Department (2003-2008) }\end{array}$ \\
\hline 24 & $\begin{array}{l}\text { France } \\
\text { (Eastern } \\
\text { Pyrénées) }\end{array}$ & 2003-2008 & $\begin{array}{l}\text { Temperate } \\
\text { mixed conifer } \\
(800-1000)\end{array}$ & Abies alba & $\begin{array}{l}\text { Lower edge to middle } \\
\text { of ranges }\end{array}$ & $\begin{array}{l}\text { Recurrent } \\
\text { drought, high } \\
\text { temperatures }\end{array}$ & $10-30$ & $\begin{array}{l}\text { Subregional; } \\
\text { patchy across } \\
\sim 150,000 \text { ha }\end{array}$ & $\begin{array}{l}\text { Bark beetles } \\
\text { (Ips, Pissodes) }\end{array}$ & $\begin{array}{l}\text { French Forest Health } \\
\text { Department (2003-2008) }\end{array}$ \\
\hline 25 & $\begin{array}{l}\text { France } \\
\text { (Provence, } \\
\text { Maures } \\
\text { Mountains) }\end{array}$ & $2006-2008$ & $\begin{array}{l}\text { Mediterranean } \\
\text { broadleaf }\end{array}$ & Quercus suber & $\begin{array}{l}\text { Northern edge to } \\
\text { middle of geographic } \\
\text { range }\end{array}$ & $\begin{array}{l}\text { Multi-year } \\
\text { drought }\end{array}$ & $10-70$ & $\begin{array}{l}\text { Subregional; } \\
\text { patchy across } \\
\sim 120,000 \text { ha }\end{array}$ & $\begin{array}{l}\text { Insects (Platypus spp., } \\
\text { Coroebus spp.) }\end{array}$ & Vennetier et al. (2008) \\
\hline
\end{tabular}

Footnotes as in Table A1.

Table A5

Documented cases of drought and/or heat-induced forest mortality from North America, 1970-present. ID numbers refer to locations mapped in Fig. 7.

\begin{tabular}{|c|c|c|c|c|c|c|c|c|c|c|}
\hline ID & Location & $\begin{array}{l}\text { Year(s) of } \\
\text { mortality }\end{array}$ & $\begin{array}{l}\text { Forest type/ } \\
\text { mean precip. }\end{array}$ & $\begin{array}{l}\text { Dominant tree } \\
\text { taxa }\end{array}$ & $\begin{array}{l}\text { Spatial } \\
\text { concentration } \\
\text { of mortality } \\
\text { within } \\
\text { geographic or } \\
\text { elevational range }\end{array}$ & $\begin{array}{l}\text { Climate anomaly } \\
\text { linked to mortality }\end{array}$ & $\begin{array}{l}\text { Stand/ } \\
\text { population- } \\
\text { level } \\
\text { mortality (\%) }\end{array}$ & $\begin{array}{l}\text { Scale of } \\
\text { impact/area } \\
\text { affected }\end{array}$ & $\begin{array}{l}\text { Biotic agents } \\
\text { associated with } \\
\text { mortality? }\end{array}$ & Reference $(s)^{d}$ \\
\hline 1 & $\begin{array}{l}\text { USA (Southeast, } \\
\text { Northeast, Midwest) }\end{array}$ & $\begin{array}{l}\text { Late 1970s- } \\
1980 \text { s }\end{array}$ & $\begin{array}{l}\text { Upland } \\
\text { temperate } \\
\text { mixed }\end{array}$ & $\begin{array}{l}\text { Quercus spp., } \\
\text { Cayra spp. }\end{array}$ & Not reported & $\begin{array}{l}\text { Multi-year droughts; } \\
\text { high temperatures } \\
\text { preceded by severe } \\
\text { winters }\end{array}$ & $\begin{array}{l}16.6 \text { in stands } \\
\text { across Southeast; } \\
1.2-6.3 \text { in Missouri }\end{array}$ & Regional & $\begin{array}{l}\text { Wood borers } \\
\text { (Agrilus } \\
\text { bilineatus); } \\
\text { fungi; insect } \\
\text { defoliators }\end{array}$ & $\begin{array}{l}\text { Stringer et al. (1989); Starkey } \\
\text { and Oak (1989); Starkey et al. } \\
\text { (1989); Clinton et al. (1993); } \\
\text { Millers et al. (1989); Tainter } \\
\text { et al. (1983); Law and Gott } \\
\text { (1987); Kessler (1989); Jenkins } \\
\text { and Pallardy (1995) }\end{array}$ \\
\hline 2 & USA (Midwest) & 1984 & $\begin{array}{l}\text { Temperate } \\
\text { deciduous }\end{array}$ & Acer spp. & Not reported & Drought & Not reported & $\begin{array}{l}\text { Landscape- } \\
\text { subregional }\end{array}$ & $\begin{array}{l}\text { Wood borers } \\
\text { (Agrilus spp.) }\end{array}$ & Millers et al. (1989) \\
\hline 3 & USA (Midwest) & 1979-1986 & $\begin{array}{l}\text { Temperate } \\
\text { deciduous }\end{array}$ & Betula spp. & Not reported & Multi-year drought & Not reported & $\begin{array}{l}\text { Landscape- } \\
\text { subregional }\end{array}$ & $\begin{array}{l}\text { leafminers; } \\
\text { wood borers; } \\
\text { birch } \\
\text { skeletonizers }\end{array}$ & Millers et al. (1989) \\
\hline 4 & USA (North Carolina) & 1984-1989 & $\begin{array}{l}\text { Temperate } \\
\text { deciduous } \\
(1270-1520)\end{array}$ & $\begin{array}{l}\text { Acer saccharum, } \\
\text { Fagus grandifolia, } \\
\text { Tilia americana, } \\
\text { Aesculus flava }\end{array}$ & Not reported & Multi-year drought & $\begin{array}{l}1.0-3.25 / \text { yr. in } \\
\text { drought years }\end{array}$ & Not reported & Not reported & Olano and Palmer (2003) \\
\hline
\end{tabular}




\begin{tabular}{|c|c|c|c|c|c|c|c|c|c|c|}
\hline ID & Location & $\begin{array}{l}\text { Year(s) of } \\
\text { mortality }\end{array}$ & $\begin{array}{l}\text { Forest type/ } \\
\text { mean precip. }{ }^{a}\end{array}$ & $\begin{array}{l}\text { Dominant tree } \\
\text { taxa }\end{array}$ & $\begin{array}{l}\text { Spatial } \\
\text { concentration } \\
\text { of mortality } \\
\text { within } \\
\text { geographic or } \\
\text { elevational range }\end{array}$ & $\begin{array}{l}\text { Climate anomaly } \\
\text { linked to mortality }\end{array}$ & $\begin{array}{l}\text { Stand/ } \\
\text { population- } \\
\text { level } \\
\text { mortality }(\%)^{\mathrm{b}}\end{array}$ & $\begin{array}{l}\text { Scale of } \\
\text { impact/area } \\
\text { affected }\end{array}$ & $\begin{array}{l}\text { Biotic agents } \\
\text { associated with } \\
\text { mortality? }\end{array}$ & Reference $(s)^{d}$ \\
\hline 5 & USA (Minnesota) & 1987-1989 & Savanna (726) & $\begin{array}{l}\text { Quercus ellipsoidalis, } \\
\text { Q. macrocarpa }\end{array}$ & Not reported & Multi-year drought & 18.2 & Not reported & Not reported & $\begin{array}{l}\text { Faber-langendoen and } \\
\text { Tester (1993) }\end{array}$ \\
\hline 6 & Eastern North America & $1980 \mathrm{~s}$ & $\begin{array}{l}\text { Temperate } \\
\text { deciduous } \\
(900-1200)\end{array}$ & Acer saccharum & $\begin{array}{l}\text { Patchy within } \\
\text { ranges }\end{array}$ & $\begin{array}{l}\text { Drought, high } \\
\text { temperatures } \\
\text { preceded by winter } \\
\text { thaw }\end{array}$ & $10-15$ & $\begin{array}{l}\text { Subregional; } \\
\text { patchy across } \\
>1 \text { M ha }\end{array}$ & $\begin{array}{l}\text { Insect defoliator } \\
\text { (Malacosoma } \\
\text { disstria) }\end{array}$ & $\begin{array}{l}\text { Hendershot and Jones (1989); } \\
\text { Payette et al. (1996); Auclair } \\
\text { et al. (1996); Roy et al. (2004); } \\
\text { Robitaille et al. (1982) }\end{array}$ \\
\hline 7 & $\begin{array}{l}\text { USA and Mexico } \\
\text { (California and Baja } \\
\text { California) }\end{array}$ & $\begin{array}{l}\text { 1985-early } \\
\text { 1990s }\end{array}$ & $\begin{array}{l}\text { Montane } \\
\text { mixed conifer } \\
(\sim 600-800)\end{array}$ & $\begin{array}{l}\text { Pinus jeffreyi, } \\
\text { Abies concolor }\end{array}$ & Not reported & Multi-year drought & $4-15$ & $\begin{array}{l}\text { Landscape- } \\
\text { subregional }\end{array}$ & $\begin{array}{l}\text { Bark beetles } \\
\text { (Dendroctonus } \\
\text { spp.) }\end{array}$ & Savage (1997) \\
\hline 8 & USA (California) & 1986-1992 & $\begin{array}{l}\text { Montane } \\
\text { mixed conifer } \\
(945)\end{array}$ & $\begin{array}{l}\text { Pinus ponderosa, } \\
\text { Calocedrus decurrens, } \\
\text { Abies concolor }\end{array}$ & Not reported & $\begin{array}{l}\text { Multi-year drought, } \\
\text { high spring and } \\
\text { summer temperatures }\end{array}$ & $23.3-69.2$ & Landscape & $\begin{array}{l}\text { Bark beetles } \\
\text { (Dendroctonus } \\
\text { spp.) }\end{array}$ & Guarin and Taylor (2005) \\
\hline 9 & USA (California) & 1986-1992 & $\begin{array}{l}\text { Montane } \\
\text { mixed conifer }\end{array}$ & Not reported & Not reported & Multi-year drought & 13 (basal area) & $\begin{array}{l}\text { Landscape- } \\
\text { subregional; } \\
56,000 \text { ha } \\
\text { affected }\end{array}$ & $\begin{array}{l}\text { Engraver } \\
\text { beetles (Scolytus } \\
\text { spp.) }\end{array}$ & $\begin{array}{l}\text { Macomber and Woodcock } \\
\text { (1994) }\end{array}$ \\
\hline 10 & USA (California) & 1986-1992 & $\begin{array}{l}\text { Montane } \\
\text { mixed conifer }\end{array}$ & Pinus spp., Abies spp. & $\begin{array}{l}\text { Drier edge of } \\
\text { local range; } \\
\text { lower edges } \\
\text { of elevational } \\
\text { ranges }\end{array}$ & Multi-year drought & Not reported & $\begin{array}{l}\text { Landscape- } \\
\text { subregional }\end{array}$ & $\begin{array}{l}\text { Primary role, } \\
\text { bark beetles } \\
\text { (Dendroctonus } \\
\text { spp.); engraver } \\
\text { beetles (Scolytus } \\
\text { spp.) }\end{array}$ & $\begin{array}{l}\text { Ferrell et al. (1994); } \\
\text { Ferrell (1996) }\end{array}$ \\
\hline 11 & USA (California) & 1985-1995 & $\begin{array}{l}\text { Montane } \\
\text { mixed conifer }\end{array}$ & Pinus flexilis & $\begin{array}{l}\text { Lower edges } \\
\text { of elevational } \\
\text { range }\end{array}$ & $\begin{array}{l}\text { Multi-year drought, } \\
\text { high temperatures }\end{array}$ & $50-75$ & $\begin{array}{l}\text { Stand- } \\
\text { landscape }\end{array}$ & $\begin{array}{l}\text { Mistletoe } \\
\text { (Arceuthobium) } \\
\text { bark beetles } \\
\text { (Dendroctonus } \\
\text { ponderosae) }\end{array}$ & Millar et al. (2007a) \\
\hline 12 & USA (Arizona) & 1996 & $\begin{array}{l}\text { Woodland } \\
(\sim 370)\end{array}$ & $\begin{array}{l}\text { Pinus edulis, } \\
\text { Juniperus } \\
\text { monosperma }\end{array}$ & $\begin{array}{l}\text { Patchy within } \\
\text { elevational range }\end{array}$ & Single-year drought & $2.3-25.9$ & $\begin{array}{l}\text { Landscape- } \\
\text { subregional }\end{array}$ & Not reported & $\begin{array}{l}\text { Mueller et al. (2005); } \\
\text { Ogle et al. (2000); Trotter (2004) }\end{array}$ \\
\hline 13 & Canada (Alberta) & 1990-1997 & $\begin{array}{l}\text { Boreal forest, } \\
\text { prairie ecotone } \\
\text { (450) }\end{array}$ & Populus tremuloides & $\begin{array}{l}\text { Patchy within } \\
\text { ranges }\end{array}$ & $\begin{array}{l}\text { Drought preceding } \\
\text { warm winter and } \\
\text { spring }\end{array}$ & $18-47$ & $\begin{array}{l}\text { Subregional; } \\
\text { patchy across } \\
\sim 1 \text { M ha }\end{array}$ & $\begin{array}{l}\text { Insect defoliator } \\
\text { (Malacosoma } \\
\text { disstria) }\end{array}$ & Hogg et al. (2002) \\
\hline 14 & $\begin{array}{l}\text { USA (Midwest, } \\
\text { Southeast) }\end{array}$ & 1990-2002 & $\begin{array}{l}\text { Upland } \\
\text { temperate } \\
\text { mixed }\end{array}$ & Quercus spp. & $\begin{array}{l}\text { Patchy within } \\
\text { ranges }\end{array}$ & Multi-year drought & $\begin{array}{l}15-50 \text { basal } \\
\text { area reduction }\end{array}$ & $\begin{array}{l}\text { Regional; } \\
\sim 1.8 \mathrm{M} \text { ha } \\
\text { affected }\end{array}$ & $\begin{array}{l}\text { Wood borers } \\
\text { (Enaphalodes } \\
\text { rufulus, Agrilus } \\
\text { spp.); fungi }\end{array}$ & $\begin{array}{l}\text { Starkey et al. (2004); } \\
\text { Oak et al. (2004); Voelker } \\
\text { et al. (2008); Heitzman } \\
\text { et al. (2004); Lawrence } \\
\text { et al. (2002) }\end{array}$ \\
\hline 15 & USA (California) & 1983-2004 & $\begin{array}{l}\text { Montane mixed } \\
\text { conifer } \\
(1100-1400)\end{array}$ & $\begin{array}{l}\text { Pinus spp., } \\
\text { Abies spp. }\end{array}$ & $\begin{array}{l}\text { Lower edges } \\
\text { of elevational } \\
\text { range }\end{array}$ & $\begin{array}{l}\text { Drought, high } \\
\text { temperatures }\end{array}$ & $\begin{array}{l}63 \% \text { increase } \\
\text { in annual } \\
\text { mortality rate }\end{array}$ & $\begin{array}{l}\text { Landscape- } \\
\text { subregional }\end{array}$ & $\begin{array}{l}\text { Insects, } \\
\text { pathogens }\end{array}$ & $\begin{array}{l}\text { van Mantgem and } \\
\text { Stephenson (2007) }\end{array}$ \\
\hline 16 & $\begin{array}{l}\text { USA and Canada } \\
\text { (Alaska, Yukon) }\end{array}$ & 1989-2004 & $\begin{array}{l}\text { Coastal rainforest, } \\
\text { boreal (485) }\end{array}$ & Picea spp. & $\begin{array}{l}\text { Patchy within } \\
\text { ranges }\end{array}$ & $\begin{array}{l}\text { Drought, high summer } \\
\text { temperatures }\end{array}$ & Not reported & $\begin{array}{l}\text { Subregional; } \\
>1.2 \mathrm{M} \mathrm{ha}\end{array}$ & $\begin{array}{l}\text { Primary role, } \\
\text { bark beetle } \\
\text { (Dendroctonus } \\
\text { rufipennis) }\end{array}$ & Berg et al. (2006) \\
\hline
\end{tabular}




\begin{tabular}{|c|c|c|c|c|c|c|c|c|c|c|}
\hline ID & Location & $\begin{array}{l}\text { Year(s) of } \\
\text { mortality }\end{array}$ & $\begin{array}{l}\text { Forest type/ } \\
\text { mean precip. }\end{array}$ & $\begin{array}{l}\text { Dominant tree } \\
\text { taxa }\end{array}$ & $\begin{array}{l}\text { Spatial } \\
\text { concentration } \\
\text { of mortality } \\
\text { within } \\
\text { geographic or } \\
\text { elevational range }\end{array}$ & $\begin{array}{l}\text { Climate anomaly } \\
\text { linked to mortality }\end{array}$ & $\begin{array}{l}\text { Stand/ } \\
\text { population- } \\
\text { level } \\
\text { mortality (\%) }\end{array}$ & $\begin{array}{l}\text { Scale of } \\
\text { impact/area } \\
\text { affected }\end{array}$ & $\begin{array}{l}\text { Biotic agents } \\
\text { associated with } \\
\text { mortality? }\end{array}$ & Reference $(s)^{d}$ \\
\hline 17 & USA (Southwest) & $2000-2004$ & $\begin{array}{l}\text { Woodland, } \\
\text { conifer } \\
(\sim 250-750)\end{array}$ & $\begin{array}{l}\text { Pinus ponderosa, } \\
\text { Pinus edulis, } \\
\text { Juniperus } \\
\text { monosperma, } \\
\text { Populus spp. }\end{array}$ & $\begin{array}{l}\text { Patchy within } \\
\text { elevational range }\end{array}$ & Multi-year drought & $\begin{array}{l}\text { 3.3-41.4 (species } \\
\text { dependant) }\end{array}$ & $\begin{array}{l}\text { Landscape- } \\
\text { subregional }\end{array}$ & Not reported & $\begin{array}{l}\text { Gitlin et al. (2006); } \\
\text { Burkett et al. (2005) }\end{array}$ \\
\hline 18 & $\begin{array}{l}\text { Southwest, USA } \\
\text { (New Mexico, } \\
\text { Arizona, Colorado, } \\
\text { Utah, Nevada) }\end{array}$ & 2000-2004 & $\begin{array}{l}\text { Woodland } \\
\text { (200-450) }\end{array}$ & $\begin{array}{l}\text { Pinus edulis, Pinus } \\
\text { monophylla, } \\
\text { Juniperus } \\
\text { monosperma, } \\
\text { Juniperus } \\
\text { scopulorum }\end{array}$ & $\begin{array}{l}\text { Patchy within } \\
\text { geographic and } \\
\text { elevational range }\end{array}$ & $\begin{array}{l}\text { Multi-year drought, } \\
\text { high spring and } \\
\text { summer } \\
\text { temperatures }\end{array}$ & $\begin{array}{l}\sim 6 \text { region-wide, } \\
0-90 \text { stand-level } \\
\text { for Pinus spp.; } \\
4.5 \text { stand-level for } \\
\text { J. monosperma }\end{array}$ & $\begin{array}{l}\text { Regional; } \\
\sim 1.2 \mathrm{M} \text { ha } \\
\text { affected }\end{array}$ & $\begin{array}{l}\text { Primary role, } \\
\text { bark beetles } \\
\text { (Ips confusus); } \\
\text { twig beetles; } \\
\text { pitch moths; } \\
\text { root fungus; } \\
\text { mistletoe }\end{array}$ & $\begin{array}{l}\text { Breshears et al. (2005); } \\
\text { Shaw et al. (2005); Swaty } \\
\text { et al. (2004); Mueller et al. } \\
\text { (2005); Allen (2007); } \\
\text { Greenwood and Weisberg } \\
\text { (2008) }\end{array}$ \\
\hline 19 & USA (Arizona) & 2001-2004 & Coniferous (180) & Pinus ponderosa & $\begin{array}{l}\text { Lower edges of } \\
\text { elevational range }\end{array}$ & $\begin{array}{l}\text { Multi-year drought, } \\
\text { high temperatures }\end{array}$ & $7-21$ & $\begin{array}{l}\text { Landscape- } \\
\text { subregional }\end{array}$ & $\begin{array}{l}\text { Primary role, } \\
\text { bark and } \\
\text { engraver } \\
\text { beetles (Ips spp.) }\end{array}$ & Negron et al. (2009) \\
\hline 20 & $\begin{array}{l}\text { Canada } \\
\text { (Saskatchewan } \\
\text { and Alberta) }\end{array}$ & $2002-2004$ & $\begin{array}{l}\text { Boreal forest, } \\
\text { prairie ecotone } \\
(360-460)\end{array}$ & $\begin{array}{l}\text { Populus } \\
\text { tremuloides }\end{array}$ & $\begin{array}{l}\text { Southern edge } \\
\text { of geographic } \\
\text { range }\end{array}$ & Multi-year drought & $\begin{array}{l}3.6 / \mathrm{yr} \text { vs. } 1.6 / \mathrm{yr} \\
\text { in non-drought yrs. }\end{array}$ & $\begin{array}{l}\text { Subcontinental; } \\
\text { patchy across } \\
\sim 10 \text { M ha }\end{array}$ & Insect defoliators & Hogg et al. (2008) \\
\hline 21 & $\begin{array}{l}\text { Canada (British } \\
\text { Columbia) }\end{array}$ & 2000-2006 & $\begin{array}{l}\text { Montane mixed } \\
\text { conifer } \\
(\sim 250-1000)\end{array}$ & Pinus contorta & $\begin{array}{l}\text { Middle of } \\
\text { geographic range }\end{array}$ & $\begin{array}{l}\text { Drought, high spring } \\
\text { and summer } \\
\text { temperatures }\end{array}$ & $\begin{array}{l}>435 \mathrm{M} \mathrm{m}^{3} \\
\text { (timber lost) }\end{array}$ & $\begin{array}{l}\text { Regional - } \\
\text { continental; } \\
\sim 13 \mathrm{M} \text { ha affected }\end{array}$ & $\begin{array}{l}\text { Primary role, } \\
\text { bark beetle } \\
\text { (Dendroctonus } \\
\text { ponderosae) }\end{array}$ & Kurz et al. (2008a) \\
\hline 22 & USA (Colorado) & 2005-2006 & $\begin{array}{l}\text { Montane mixed } \\
(380-1100)\end{array}$ & Populus tremuloides & $\begin{array}{l}\text { Patchy but } \\
\text { concentrated at } \\
\text { lower edges of } \\
\text { elevational range }\end{array}$ & $\begin{array}{l}\text { Multi-year drought, } \\
\text { high spring and } \\
\text { summer temperatures. }\end{array}$ & $\begin{array}{l}32 \text { (stand scale); } \\
5.62 \text { (landscape } \\
\text { scale) }\end{array}$ & $\begin{array}{l}\text { Landscape- } \\
\text { subregional; } \\
58,374 \text { ha affected }\end{array}$ & $\begin{array}{l}\text { Wood borers; } \\
\text { cytospora } \\
\text { canker; bark } \\
\text { beetles }\end{array}$ & Worrall et al. (2008) \\
\hline 23 & $\begin{array}{l}\text { USA } \\
\text { (Western States) }\end{array}$ & 1955-2007 & $\begin{array}{l}\text { All western } \\
\text { forest types }\end{array}$ & Many species & Not reported & High temperatures & $\begin{array}{l}3.9 \text {-fold increase } \\
\text { in annual mortality } \\
\text { rate }\end{array}$ & Regional & Not reported & van Mantgem et al. (2009) \\
\hline 24 & $\begin{array}{l}\text { Western North } \\
\text { America }\end{array}$ & $1997-2007$ & Coniferous & $\begin{array}{l}\text { Pinus spp., Picea } \\
\text { spp., Abies spp., } \\
\text { Pseudotsuga } \\
\text { menziesii }\end{array}$ & Not reported & $\begin{array}{l}\text { Drought, high } \\
\text { temperatures }\end{array}$ & Not reported & $\begin{array}{l}\text { Regional; } \\
60.7 \mathrm{M} \mathrm{ha} \\
\text { affected }\end{array}$ & $\begin{array}{l}\text { Primary role, } \\
\text { bark and } \\
\text { engraver beetles } \\
\text { (Dendroctonus, } \\
\text { Ips, Dryocoetes, } \\
\text { Scolytus spp.) }\end{array}$ & Bentz et al. (2009) \\
\hline 25 & USA (Minnesota) & 2004-2007 & $\begin{array}{l}\text { Boreal and } \\
\text { temperate mixed } \\
(480-900)\end{array}$ & $\begin{array}{l}\text { Populus } \\
\text { tremuloides, } \\
\text { Fraxinus spp. }\end{array}$ & $\begin{array}{l}\text { Lower edges } \\
\text { and middle of } \\
\text { ranges }\end{array}$ & Drought & Not reported & Not reported & Insect defoliators & $\begin{array}{l}\text { Minnesota Dept. Nat. } \\
\text { Resources (2007) }\end{array}$ \\
\hline 26 & USA (California) & $\begin{array}{l}\text { 1998-2001, } \\
2005-2008\end{array}$ & Not reported & Not reported & Not reported & $\begin{array}{l}\text { Drought preceded } \\
\text { by wet, warm episodes }\end{array}$ & $\begin{array}{l}423,000 \text { dead tress } \\
\text { in northern California }\end{array}$ & $\begin{array}{l}\text { Landscape- } \\
\text { subregional }\end{array}$ & $\begin{array}{l}\text { Primary role, } \\
\text { pathogen } \\
\text { (Phytophthora } \\
\text { ranorum) }\end{array}$ & Garrett et al. (2006) \\
\hline 27 & $\begin{array}{l}\text { Canada and USA } \\
\text { (Alaska, } \\
\text { British Columbia) }\end{array}$ & $\begin{array}{l}\text { Long-term } \\
1880-2008\end{array}$ & $\begin{array}{l}\text { Temperate coastal } \\
\text { rainforest } \\
(1300-4000)\end{array}$ & $\begin{array}{l}\text { Chamaecyparis } \\
\text { nootkatensis }\end{array}$ & Middle & $\begin{array}{l}\text { Warmer winters } \\
\text { and springs }\end{array}$ & $70 \%$ of basal area lost & $\begin{array}{l}\text { Subregional; } \\
\sim 200,000 \text { ha } \\
\text { affected }\end{array}$ & None & $\begin{array}{l}\text { Beier et al. (2008); Hennon } \\
\text { and Shaw (1997); Hennon } \\
\text { et al. (2005) }\end{array}$ \\
\hline
\end{tabular}


Table A6

Documented cases of drought and/or heat-induced forest mortality from South and Central America, 1970-present. ID numbers refer to locations mapped in Fig. 8.

\begin{tabular}{|c|c|c|c|c|c|c|c|c|c|c|}
\hline ID & Location & $\begin{array}{l}\text { Year(s) of } \\
\text { reported } \\
\text { mortality }\end{array}$ & $\begin{array}{l}\text { Forest type/ } \\
\text { mean precip. }{ }^{a}\end{array}$ & $\begin{array}{l}\text { Dominant } \\
\text { tree taxa }\end{array}$ & $\begin{array}{l}\text { Spatial } \\
\text { concentration } \\
\text { of mortality } \\
\text { within geographic } \\
\text { or elevational range }\end{array}$ & $\begin{array}{l}\text { Climate anomaly } \\
\text { linked to mortality }\end{array}$ & $\begin{array}{l}\text { Stand/population-level } \\
\text { mortality }(\%)^{\mathrm{b}}\end{array}$ & $\begin{array}{l}\text { Scale of impact/ } \\
\text { area affected (ha) }\end{array}$ & $\begin{array}{l}\text { Biotic agents } \\
\text { associated with } \\
\text { mortality? }\end{array}$ & Reference $(s)^{d}$ \\
\hline 1 & $\begin{array}{l}\text { Panama } \\
\text { (Panama) }\end{array}$ & 1982-1985 & $\begin{array}{l}\text { Tropical rainforest } \\
(2600)\end{array}$ & $\begin{array}{l}205 \text { different } \\
\text { species }\end{array}$ & Not reported & $\begin{array}{l}\text { Seasonal drought, } \\
\text { high temperatures }\end{array}$ & $\begin{array}{l}2.75 / \text { yr vs. } 1.98 / \mathrm{yr} \text { in } \\
\text { non-drought years }\end{array}$ & Not reported & Not reported & $\begin{array}{l}\text { Condit et al. (1995); } \\
\text { Leigh et al. (1990) }\end{array}$ \\
\hline 2 & $\begin{array}{l}\text { Brazil } \\
\text { (Espírito } \\
\text { Santo) }\end{array}$ & $\begin{array}{l}\text { 1986-1989, } \\
1997-1999\end{array}$ & $\begin{array}{l}\text { Tropical rainforest } \\
\text { (1200) }\end{array}$ & Not reported & Not reported & Seasonal drought & $\begin{array}{l}4.5 / \text { yr vs. } 1.4 / y r \text { in } \\
\text { non-drought years }\end{array}$ & Not reported & Not reported & Rolim et al. (2005) \\
\hline 3 & $\begin{array}{l}\text { Brazil } \\
\text { (Amazonas) }\end{array}$ & 1997 & $\begin{array}{l}\text { Tropical rainforest } \\
(2000)\end{array}$ & Not reported & Not reported & Seasonal drought & $\begin{array}{l}1.9 / \mathrm{yr} \text { vs. } 1.21-1.23 / \mathrm{yr} \\
\text { in non-drought years }\end{array}$ & Not reported & Not reported & $\begin{array}{l}\text { Williamson et al. } \\
\text { (2000); Laurance } \\
\text { et al. (2001) }\end{array}$ \\
\hline 4 & $\begin{array}{l}\text { Costa Rica } \\
\text { (Heredia) }\end{array}$ & 1998 & $\begin{array}{l}\text { Tropical rainforest } \\
(3962)\end{array}$ & Not reported & Not reported & Seasonal drought & $\begin{array}{l}3.1 / \mathrm{yr} \text { vs. } 1.6 / \mathrm{yr} \text { in } \\
\text { non-drought years }\end{array}$ & Not reported & Not reported & Chazdon et al. (2005) \\
\hline 5 & $\begin{array}{l}\text { Argentina } \\
\text { (western } \\
\text { Neuquén, } \\
\text { Rio Negro) }\end{array}$ & 1998-1999 & $\begin{array}{l}\text { Temperate } \\
\text { steppe - Montane } \\
\text { broadleaf } \\
(500-1500)\end{array}$ & $\begin{array}{l}\text { Nothofagus } \\
\text { dombeyi }\end{array}$ & $\begin{array}{l}\text { Arid edge of } \\
\text { geographic range; } \\
\text { lower elevations }\end{array}$ & $\begin{array}{l}\text { Seasonal drought, } \\
\text { high temperatures }\end{array}$ & $11-57$ & $\begin{array}{l}\text { Landscape- } \\
\text { subregional }\end{array}$ & $\begin{array}{l}\text { Wood borers; } \\
\text { woodpeckers }\end{array}$ & $\begin{array}{l}\text { Suarez et al. (2004); } \\
\text { Suarez and Kitzberger } \\
\text { (2008); Bran et al. (2001) }\end{array}$ \\
\hline 6 & Amazon Basin & 2005 & Tropical rainforest & Not reported & Not reported & Single year drought & 1.2-1.6 Pg C lost & Subcontinental & Not reported & Phillips et al. (2009) \\
\hline
\end{tabular}

Footnotes as in Table A1. 


\section{References}

Adams, H.D., Guardiola-Claramonte, M., BarronGafford, G.A., Villegas, J.C., Breshears, D.D., Zou, C.B., Troch, P.A., Huxman, T.E., 2009. Temperature sensitivity of drought-induced tree mortality: implications for regional die-off under global-changetype drought. Proceedings of the National Academy of Sciences of the United States of America 106, 7063 7066.

Adil, S., 2008. Climate change and forest in Morocco: case of the decay of the cedar in the Atlas Mountains. In: Poster Presentation At: International Conference "Adaptation of Forests and Forest Management to Changing Climate with

Emphasis on Forest Health: A Review of Science, Policies, and Practices", Umea ${ }^{\circ}$, Sweden: FAO/IUFRO, 25-28 August 2008.

Aiba, S.I., Kitayama, K., 2002. Effects of the 1997-98 El Nino drought on rain forests of Mount Kinabalu, Borneo. Journal of Tropical Ecology 18, 215-230.

Albertson, F.W., Weaver, J.E., 1945. Injury and death or recovery of trees in prairie climate. Ecological Monographs 15, 393-433.

Allen, C.D., 2007. Interactions across spatial scales among forest dieback, fire, and erosion in northern New Mexico landscapes. Ecosystems 10, 797-808.

Allen, C.D., 2009. Climate-induced forest dieback: an escalating global phenomenon? Unasylva 231/232 (60), 43-49.

Allen, C.D., Breshears, D.D., 1998. Drought-induced shift of a forest-woodland ecotone: rapid landscape response to climate variation. Proceedings of the National Academy of Sciences of the United States of America 95, 14839- 14842.

Allen, C.D., Breshears, D.D., 2007.In: Meetings: Organized Oral Session on "Climate- Induced Forest Dieback as an Emergent Global Phenomenon: Patterns, Mechanisms, and Projections'. Annual Meeting of Ecological Society of America EOS 88(47), San Jose, California, 7 August 2007, p. 504.

Amthor, J.S., 2000. The McCree-de-Wit-Penning de Vries-Thornley respiration paradigms: 30 years later. Annals of Botany 86, 1-20.

Auclair, A.N.D., 1993. Extreme climatic fluctuations as a cause of forest dieback in the Pacific Rim. Water Air and Soil Pollution 66 (3-4), 207-229.

Auclair, A.N., Lill, D., Revenga, J.T.C., 1996. The role of climate variability and global warming in the dieback of Northern Hardwoods. Water, Air, and Soil Pollution 91, 163-186.

Ayres, M.P., Lombardero, M.J., 2000. Assessing the consequences of global change for forest disturbances for herbivores and pathogens. Science of the Total Environment 262, 263-286.
Bachelet, D., Neilson, R.P., Hickler, T., Drapek, R.J., Lenihan, J.M., Sykes, M.T., Smith, B., Sitch, S., Thonicke, K., 2003. Simulating past and future dynamics of natural ecosystems in the United States. Global Biogeochemistry Cycles 17, 1045 doi:10.1029/2001GB001508.

Bale, J.S., Masters, G.J., Hodkinson, I.D., Awmack, C., Bezemer, T.M., Brown, V.K., Butterfield, J., Buse, A., Coulson, J.C., Farrar, J., Good, J.E., Harrington, R., Hartley, S., Jones, T.H., Lindroth, R.L., Press, M.C., Symrnioudis, I., Watt, A.D., Whittaker, J.B., 2002. Herbivory in a global climate change research: direct effects of rising temperature on insect herbivores. Global Change Biology 88, 1-16.

Barber, V.A., Juday, G.P., Finney, B.P., 2000. Reduced growth of Alaskan white spruce in the twentieth century from temperature-induced drought stress. Nature 405, 668-673.

Becker, P., Lye, O.C., Goh, F., 1998. Selective drought mortality of dipterocarp trees: no correlation with timber group distributions in Borneo. Biotropica 30, 666-671.

Beier, C.M., Sink, S.E., Hennon, P.E., D’Amore, D.V., Juday, G.P., 2008. Twentieth century warming and the dendroclimatology of declining yellow-cedar forests in southeastern Alaska. Canadian Journal of Forest Research 38, 1319-1334.

Bentouati, A., 2008. La situation du cèdre de l'Atlas en Algérie. Forêt Méditerranéenne 29, 203-209.

Bentouati, A., Bariteau, M., 2006. Réflexions sur le dépérissement du cèdre de l'Atlas des Aurès (Algérie). Forêt Méditerranéenne 27, 317-322.

Bentz, B.J., Allen, C.D., Ayres, M., Berg, E., Carroll, A., Hansen, M., Hicke, J., Joyce, L., Logan, J., MacFarlane, W., MacMahon, J., Munson, S., Negron, J., Paine, T., Powell, J., Raffa, K., Re' gnie' re, J., Reid, M., Romme, W., Seybold, S., Six, D., Tomback, D., Vandygriff, J., Veblen, T., White, M., Witcosky, J., Wood, D., 2009. In: Bentz, B.J. (Ed.), Bark Beetle Outbreaks in Western North America: Causes and Consequences. Univ. of Utah Press, , ISBN: 978-087480965-7p. 42.

Berg, E.E., Henry, J.D., Fastie, C.L., De Volder, A.D., Matsuoka, S.M., 2006. Spruce beetle outbreaks on the Kenai Peninsula, Alaska, and Kluane National Park and Reserve, Yukon Territory: relationship to summer temperatures and regional differences in disturbance regimes. Forest Ecology and Management 227, 219 232.

Biasutti, M., Giannini, A., 2006. Robust Sahel drying in response to late 20th century forcings. Geophysics Research Letters 33, L11706 doi:10.1029/2006GL026067.

Bigler, C., Braker, O.U., Bugmann, H., Dobbertin, M., Rigling, A., 2006. Drought as an inciting mortality factor in Scots pine stands of the Valais, Switzerland. Ecosystems 9, 330-343. 
Bigler, C., Gavin, D.G., Gunning, C., Veblen, T.T., 2007. Drought induces lagged tree mortality in a subalpine forest in the Rocky Mountains. Oikos 116, 1983-1994.

Boisvenue, C., Running, S.W., 2006. Impacts of climate change on natural forest productivityevidence since the middle of the 20th century. Global Change Biology 12, 1-21.

Bonan, G.B., 2008. Forests and climate change: forcings, feedbacks, and the climate benefits of forests. Science 320, 1444-1449.

Bran, D., Pérez, A., Ghermandi, L., Barrios Lamunière, S.D., 2001. Evaluación de poblaciones de coihue (Nothofagus dombeyi) del Parque Nacional Nahuel Huapi, afectadas por la sequi'a 98/99, a escala de paisaje $(1: 250.000)$.

Breda, N., Huc, R., Granier, A., Dreyer, E., 2006. Temperate forest trees and stands under severe drought: a review of ecophysiological responses, adaptation processes and long-term consequences. Annals of Forest Science 63, 625-644.

Breshears, D.D., Allen, C.D., 2002. The importance of rapid, disturbance-induced losses in carbon management and sequestration. Global Ecology and Biogeography Letters 11, 1-15.

Breshears, D.D., Cobb, N.S., Rich, P.M., Price, K.P., Allen, C.D., Balice, R.G., Romme, W.H., Kastens, J.H., Floyd, M.L., Belnap, J., Anderson, J.J., Myers, O.B., Meyer, C.W., 2005. Regional vegetation die-off in response to global-change-type drought. Proceedings of the National Academy of Sciences of the United States of America 102 (42), 15144-15148.

Breshears, D.D., Myers, O.B., Meyer, C.W., Barnes, F.J., Zou, C.B., Allen, C.D., McDowell, N.G., Pockman, W.T., 2009. Tree die-off in response to global-change-type drought: mortality insights from a decade of plant water potential measurements. Frontiers in Ecology and Environment 7, 185-189.

Brunner, I., Graf-Pannatier, E., Frey, B., Rigling, A., Landolt, W., Dobbertin, M., 2009. Morphological and physiological responses of Scots pine fine roots to water supply in a climatic dry area in Switzerland. Tree Physiology 29, 542-550.

Bugmann, H.K.M., Wullschleger, S.D., Price, D.T., Ogle, K., Clark, D.F., Solomon, A.M., 2001. Comparing the performance of forest gap models in North America. Climatic Change 51, 349-388.

Burkett, V.R., Wilcox, D.A., Stottlemyer, R., Barrow, W., Fagre, D., Baron, J., Price, J., Nielsen, J.L., Allen, C.D., Peterson, D.L., Ruggerone, G., Doyle, T., 2005. Nonlinear dynamics in ecosystem response to climatic change: case studies and policy implications. Ecological Complexity 2, 357-394.

Caldeira, M.C., Fernande' z, V., Tome' , J., Pereira, J.S., 2002. Positive effect of drought on longicorn borer larval survival and growth on eucalyptus trunks. Annals of Forest Science 59, 99-106.
Cech, T., Perny, L.B., 2000. Kiefernsterben in Tirol. Forstschutz-aktuell 22, 12-15.

Cech, T., Tomiczek, C., 1996. Zum Kiefernsterben in Niederö sterreich. Forstschutzaktuell 17/18, 12-13.

Chapin III, F.S., Randerson, A.D., McGuire, A.D., Foley, J.A., Field, C.B., 2008. Changing feedbacks in the climate-biosphere system. Frontiers in Ecology and the Environment 6, 313-320.

Chazdon, R.L., Brenes, A.R., Alvarado, B.V., 2005. Effects of climate and stand age on annual tree dynamics in tropical second-growth rain forests. Ecology 86, 1808-1815.

Chenchouni, H., Abdelkrim, S.B., Athmane, B., 2008. The deterioration of the Atlas Cedar (Cedrus atlantica) in Algeria. Oral presentation at: International Conference 'Adaptation of Forests and Forest Management to Changing Climate withEmphasis on Forest Health: A Review of Science, Policies, and Practices', Umea ${ }^{\circ}$, Sweden: FAO/IUFRO, 25-28 August 2008.

Christensen, J.H., Hewitson, B., Busuioc, A., Chen, A., Gao, X., Held, I., Jones, R., Kolli, R.K., Kwon, W.-T., Laprise, R., Magaña Rueda, V., Mearns, L., Menéndez, C.G., Räisänen, J., Rinke, A., Sarr, A., Whetton, P., 2007. Regional climate projections. In: Solomon, S., et al. (Eds.), Climate Change 2007: The Physical Science Basis. Contributions of Working Group I to the Fourth Assessment Report of the Intergovernmental Panel on Climate Change. Cambridge University Press, Cambride, United Kingdom/New York, NY.

Chuprov, N.P., 2007. The problem of dying spruce stands in forests of the Russian European North. In: Dying Spruce Forests of Arkhangelsk Region, Problems and Means of their Solution, Department of Forest Complex of Arkhangelsk Region, Arkhangelsk, Russian Federation, pp. 66-71.

Ciais, P., Reichstein, M., Viovy, N., Granier, A., Ogee, J., Allard, V., Aubinet, M., Buchmann, N., Bernhofer, C., Carrara, A., Chevallier, F., De Noblet, N., Friend, A.D., Friedlingstein, P., Grunwald, T., Heinesch, B., Keronen, P., Knohl, A., Krinner, G., Loustau, D., Manca, G., Matteucci, G., Miglietta, F., Ourcival, J.M., Papale, D., Pilegaard, K., Rambal, S., Seufert, G., Soussana, J.F., Sanz, M.J., Schulze, E.D., Vesala, T., Valentini, R., 2005. Europe-wide reduction in primary productivity caused by the heat and drought in 2003 . Nature 437 (7058), 529- 533.

Ciesla, W.M., Donaubauer, M.E., 1994. Decline and dieback of trees and forests: a global overview. FAO Forestry Paper 120, 90.

Clinton, B.D., Boring, L.R., Swank, W.T., 1993. Canopy gap characteristics and drought influences in oak forests of the Coweeta Basin. Ecology 74, 15511558.

Condit, R., Hubbell, S.P., Foster, R.B., 1995. Mortality-rates of 205 neotropical tree and shrub species and the impact of a severe drought. Ecological Monographs 65, 419-439. 
Damesin, C., 2003. Respiration and photosynthesis characteristics of current-year stems of Fagus sylvatica: from the seasonal pattern to an annual balance. New Phytologist 158, 465-475.

Delatour, C., 1983. Les dépérissements de chênes en Europe (Oak die-back in Europe). Revue forestière française 35 (4), 265-282.

Desprez-Loustau, M.-L., Marcais, B., Nageleisen, L.M., Piou, D., Vannini, A., 2006. Interactive effects of drought and pathogens in forest trees. Annals of Forensic Science 63, 597-612.

Dobbertin, M., Rigling, A., 2006. Pine mistletoe (Viscum album ssp. austriacum) contributes to Scots pine (Pinus sylvestris) mortality in the Rhone valley of Switzerland. Forest Pathology 36, 309-322.

Dobbertin, M., Mayer, P., Wohlgemuth, T., FeldmeyerChriste, E., Graf, U., Zimmermann, N.E., Rigling, A., 2005. The decline of Pinus sylvestris L. forests in the swiss Rhone Valley-a result of drought stress? Phyton-Annales Rei Botanicae 45, 153-156.

Dobbertin, M.,Wermelinger, B., Bigler, C., Buergi, M., Carron, M., Forster, B., Gimmi, U., Rigling, A., 2007. Linking increasing drought stress to Scots pine mortality and bark beetle infestations. The Scientific World Journal 7, 231-239.

El Abidine, A.Z., 2003. Forest decline in Morocco: causes and control strategy. Science et changements plane' taires/Sécheresse 14, 209-218.

Elliott, K.J., Swank, W.T., 1994. Impacts of drought on tree mortality and basal area growth in a mixed hardwood forest of the Coweeta Basin. Journal of Vegetation Science 5, 229-236.

Ermolenko, A., 2008. Climate change and mass-scale forest dieback: regional, national and international aspects. Oral presentation at: International Conference "Adaptation of Forests and Forest Management to Changing Climate with

Emphasis on Forest Health: A Review of Science, Policies, and Practices", Umea ${ }^{\circ}$, Sweden: FAO/IUFRO, 25-28 August 2008.

Faber-langendoen, D., Tester, J.R., 1993. Oak mortality in sand savannas following drought in EastCentral Minnesota. Bulletin of the Torrey Botanical Club 120, 248-256.

FAO, 2006. Global forest resources assessment 2005progress towards sustainable forest management. FAO Forestry Paper No. 147. Rome.

FAO, 2007. Forest monitoring and assessment for climate change reporting: partnerships, capacity building and delivery. Holmgren, P., L.-G. Marklund, M. Saket, M.L. Wilkie. FAO Forest Resources Assessment Working Paper No. 142. Rome.

Fensham, R.J., 1998. The influence of cattle grazing on tree mortality after drought in savanna woodland in north Queensland. Australian Journal of Ecology 23, 405- 407 .
Fensham, R.J., Fairfax, R.J., 2007. Drought-related tree death of savanna eucalypts: species susceptibility, soil conditions and root architecture. Journal of Vegetation Science 18, 71-80.

Fensham, R.J., Fairfax, R.J., 2005. Preliminary assessment of gidgee (Acacia cambagei) woodland thickening in the Longreach district, Queensland. The Rangeland Journal 27, 159-168.

Fensham, R.J., Holman, J.E., 1999. Temporal and spatial patterns in drought-related tree dieback in Australian savanna. Journal of Applied Ecology 36, 1035-1050.

Fensham, R.J., Fairfax, R.J., Butler, D.W., Bowman, D.M.J.S., 2003. Effects of fire and drought in a tropical eucalypt savanna colonized by rain forest. Journal of Biogeography 30, 1405-1414.

Fensham, R.J., Fairfax, R.J., Ward, D.P., 2009. Drought-induced tree death in savanna. Global Change Biology 15, 380-387.

Ferrell, G.T., 1996. The influence of insect pests and pathogens on Sierra Forests. In: Sierra Nevada Ecosystem Project: Final Report to Congress, vol. II, Assessments and Scientific Basis for Management Options. Univ. of California, Davis, Water Resources Center Report No. 37, pp. 1177-1192.

Ferrell, G.T., Otrosina, W.J., Demars, C.J., 1994. Predicting susceptibility of white fir during a droughtassociated outbreak of the fir engraver, Scolytus ventralis, in California. Can. J. For. Res. 24, 302-305.

Fisher, M., 1997. Decline in the juniper woodlands of Raydah reserve in southwestern Saudi Arabia: a response to climate changes? Global Ecology and Biogeography Letters 6, 379-386.

Fisher, M., Gardner, A.S., 1995. The status and ecology of a Juniperus-Excelsa subsp. Polycarpos woodland in the northern mountains of Oman. Vegetatio 119, 33-51.

Floyd, M.L., Clifford, M., Cobb, N.S., Hanna, D., Delph, R., Ford, P., Turner, D., 2009. Relationship of stand characteristics to drought-induced mortality in three Southwestern piñon-juniper woodlands. Ecological Applications 19 (5), 1223- 1230.

Foden, W.,Midgley, G.F., Hughes, G., Bond, W.J., Thuiller, W., Hoffman, M.T., Kaleme, P., Underhill, L.G., Rebelo, A., Hannah, L., 2007. A changing climate is eroding the geographical range of the Namib Desert tree Aloe through population declines and dispersal lags. Diversity and Distributions 13, 645-653.

Forster, B., Meier, F., Braendli, U.-B., 2008. Deutlicher Ru“ ckgang der Fichten im Mittelland. Vorratsabbau - auch durch Sturm und $\mathrm{Ka}^{*}$ fer. Wald Holz 89 (3), 52- 54.

Fowler, D., Cape, J.N., Coyle, M., Flechard, C., Kuylenstierna, J., Hicks, K., Derwent, D., Johnson, C., Stevenson, D., 1999. The global exposure of forests to air pollutants. Water, Air, and Soil Pollution 116, 5-32. 
Franklin, J.F., Shugart, H.H., Harmon, M.E., 1987. Tree death as an ecological process. Bioscience 27, 259-288.

French Forest Health Department (Département Santé des Forêts), 1998-1999, 2003-2008 Annual Reports.

Gan, J.B., 2004. Risk and damage of southern pine beetle outbreaks under global climate change. Forest Ecology and Management 191, 61-71.

Gardner, A.S., Fisher, M., 1996. The distribution and status of the montane juniper woodlands of Oman. Journal of Biogeography 23, 791-803.

Garrett, K.A., Dendy, S.P., Frank, E.E., Rouse, M.N., Travers, S.E., 2006. Climate change effects on plant disease: genomes to ecosystems. Annual Review of Phytopathology 44, 489-509.

Gitlin, A.R., Sthultz, C.M., Bowker, M.A., Stumpf, S., Paxton, K.L., Kennedy, K., Munoz, A., Bailey, J.K., Whitham, T.G., 2006. Mortality gradients within and among dominant plant populations as barometers of ecosystem change during extreme drought. Conservation Biology 20, 1477-1486.

Gonzalez, P., 2001. Desertification and a shift of forest species in the West African Sahel. Climate Research $17,217-228$.

Grant, P.J., 1984. Drought effect on high-altitude forests, Ruahine Range, North Island, New Zealand. New Zealand Journal of Botany 22 (1), 15-27.

Greenwood, D.L., Weisberg, P.J., 2008. Densitydependent tree mortality in pinyon-juniper woodlands. Forest Ecology and Management 255, 2129-2137.

Grulke, N.E., Paine, T., Minnich, R., Chavez, D., Riggan, P., Dunn, A., 2009. Air pollution increases forest susceptibility to wildfire. In: Bytnerowicz, A., Arbaugh, M., Riebau, A., Andersen, C. (Eds.), Wildland Fires and Air Pollution. Developments in Environmental Science, vol. 8. Elsevier Publishers, The Hague, Netherlands, pp. 365-403.

Guarin, A., Taylor, A.H., 2005. Drought triggered tree mortality in mixed conifer forests in Yosemite National Park, California, USA. Forest Ecology and Management 218, 229-244.

Gutschick, V.P., BassiriRad, H., 2003. Extreme events as shaping physiology, ecology, and evolution of plants: toward a unified definition and evaluation of their consequences. New Phytologist 160, 21-42.

Hamann, A., Wang, T., 2005. Models of climatic normals for genecology and climate change studies in British Columbia. Agricultural and Forest Meteorology 128, 211-221.

Hanson, P.J., Weltzin, J.F., 2000. Drought disturbance from climate change: response of United States forests. Science of the Total Environment 262, 205-220.
Heitzman, E., Muzika, R.M., Kabrick, J., Guldin, J.M., 2004. Assessment of oak decline in Missouri, Arkansas, and Oklahoma. In: Yaussy, D.A., et al. (Eds.), Proceedings of the 14th Central Hardwood Forest Conference, Wooster, OH, 16-19 March 2004. Gen. Tech. Rep. NE-316. USDA Forest Service, Northeastern Research Station, Newtown Square, PA pp. 510 .

Hendershot, W.H., Jones, A.R.C., 1989. Maple decline in Quebec: a discussion of possible causes and the use of fertilizers to limit damage. Forestry Chronicle 65 (4), 280-287.

Hennon, P.E., Shaw, C.G., 1997. The enigma of yellow-cedar decline-What is killing these long-lived, defensive trees? Journal of Forestry 95, 4-10.

Hennon, P.E., D'Amore, D.V., Zeglen, S., Grainger, M., 2005. Yellow-cedar decline in the North Coast Forest District of British Columbia. In: USDA Forest Service Research Note PNW-RN-549, Pacific Northwest Research Station, 16 pp.

Hicke, J.A., Logan, J.A., Powell, J., Ojima, D.S., 2006. Changing temperatures influence suitability for modeled mountain pine beetle (Dendroctonus ponderosae) outbreaks in the western United States. Journal of Geophysical Research 111, G02019 doi:10.1029/2005JG000101.

Hogg, E.H., Brandt, J.P., Kochtubajda, B., 2002. Growth and dieback of Aspen forests in northwestern Alberta, Canada, in relation to climate and insects. Canadian Journal of Forest Research-Revue Canadienne De Recherche Forestière 32, 823-832.

Hogg, E.H., Brandt, J.P., Michaellian, M., 2008. Impacts of a regional drought on the productivity, dieback, and biomass of western Canadian aspen forests. Canadian Journal of Forest Research-Revue Canadienne De Recherche Forestière 38, 1373-1384.

Holst, J., Barnard, R., Brandes, E., Buchmann, N., Gessler, A., Jaeger, L., 2008. Impacts of summer water limitation on the carbon balance of a Scots pine forest in the southern upper Rhine plain. Agricultural and Forest Meteorology 148, 1815-1826.

Horner, G.J., Baker, P.J., MacNally, R., Cunningham, S.C., Thomson, J.R., Hamilton, F., 2009. Mortality of developing floodplain forests subjected to a drying climate and water extraction. Global Change Biology 15, 2176-2186.

Hosking, G.P., Hutcheson, J.A., 1988. Mountain beech (Nothofagus-Solandri var. Cliffortioides) decline in the Kaweka Range, North Island, New Zealand. New Zealand Journal of Botany 26, 393-400.

Hosking, G.P., Kershaw, D.J., 1985. Red Beech death in the Maruia Valley South Island, New Zealand. New Zealand Journal of Botany 23, 201-211. 
Huntingford, C., Fisher, R.A., Mercado, L., Booth, B.B.B., Sitch, S., Harris, P.P., Cox, P.M., Jones, C.D., Betts, R.A., Malhi, Y., Harris, G., Collins, M., Moorcroft, P., 2008. Towards quantifying uncertainty in predictions of Amazon "Die-back'. Philosophical Transactions of the Royal Society B-Biological Sciences 363 (1498), 1857-1864.

Hursh, C.R., Haasis, F.W., 1931. Effects of 1925 summer drought on Southern Appalachian hardwoods. Ecology 12, 380-386.

Huxman, T.E., Wilcox, B.P., Breshears, D.D., Scott, R., Snyder, K., Small, E.A., Hultine, K., Pockman, W., Jackson, R.B., 2005. Woody plant encroachment and the water cycle: an ecohydrological framework. Ecology 86, 308-319.

IPCC, 2007a. Climate change 2007: the physical science basis. In: Solomon, S., Qin, D., Manning, M., Chen, Z., Marquis, M., Averyt, K.B., Tignor, M., Miller, H.L. (Eds.), Contribution of Working Group I to the Fourth Assessment. Report of the Intergovernmental Panel on Climate Change. Cambridge University Press, Cambridge,

United Kingdom/New York, NY, USA, 996 pp.

IPCC, 2007b. Climate change 2007: impacts, adaptation and vulnerability. Parry, M.L., Canziani, O.F., Palutikof, J.P., van der Linden, P.J., Hanson, C.E. (eds.), Contribution of Working Group II to the Fourth Assessment Report of the Intergovernmental Panel on Climate Change. Cambridge University Press, Cambridge, UK, 976 pp.

Jenkins, M.A., Pallardy, S.G., 1995. The influence of drought on red oak group species growth and mortality in the Missouri Ozarks. Canadian Journal of Forest Research-Revue Canadienne De Recherche Forestière 25, 1119-1127.

Jentsch, A., Kreyling, J., Beierkuhnlein, C., 2007. A new generation of climate change experiments: events, not trends. Frontiers in Ecology and the Environment 5, 365-374.

Jones, C., Lowe, J., Liddicoat, S., Betts, R., 2009. Committed terrestrial ecosystem changes due to climate change. Nature GeoScience 2, 484-487.

Joyce, L.A., Blate, G.M., Littell, J.S., McNulty, S.G., Millar, C.I., Moser, S.C., Neilson, R.P., O’Halloran, K., Peterson, D.L., 2008. Chapter 3, National forests. In: Preliminary Review of Adaptation Options for Climate-Sensitive Ecosystems and Resources. A Report by the U.S. Climate Change Science Program and the Subcommittee on Global Change Research. U.S. Environmental Protection Agency, Washington, DC, pp. 3-1-3-127.

Jump, A.S., Ma' tya' s, C., Peñuelas, J. 2009. The altitude-for-latitude disparity in the range retractions of woody species. Trends in Ecology and Evolution, doi:10:1016/j.tree.2009.06.007.

Kailidis, D.L., Markalas, S., 1990. Dryness and the most destructive secondary bark beetle epidemic on fir in Greece. Ecotopia 8, 38-41.
Karnosky, D.F., Pregitzer, K.S., Zak, D.R., Kubiske, M.E., Hendrey, G.R., Weinstein, D., Nosal, M., Percy, K.E., 2005. Scaling ozone responses of forest trees to the ecosystem level in a changing climate. Plant, Cell and Environment 28, 965-981.

Kauhanen, H., Wallenius, T., Kuuluvainen, T., Aakala, T., Mikkola, K., 2008. Extensive mortality of spruce forests in Arkhangelsk Region: satellite image analysis. In: Poster Presentation At: International Conference "Adaptation of Forests and Forest Management to Changing Climate with Emphasis on Forest Health: A Review of Science, Policies, and Practices", Umea , Sweden, FAO/IUFRO, 25-28 August 2008.

Keane, R.E., Austin, M., Field, C., Huth, A., Lexer, M.J., Peters, D., Solomon, A., Wyckoff, P., 2001. Tree mortality in gap models: application to climate change. Climatic Change 51, 509-540.

Kessler Jr., K.J., 1989. Some perspectives on oak decline in the 80's. In: Rink, G., Budelsky, C.A. (Eds.), Proceedings of the Seventh Central Hardwood Conference. Gen. Tech. Rep. NC-132, U.S. Department of Agriculture, Forest Service, North Central Research Station, St. Paul, MN, pp. 25-29.

Khan, J.A., Rodgers, W.A., Johnsingh, A.J.T., Mathur, P.K., 1994. Tree and shrub mortality and debarking by Sambar Cervus-Unicolor (Kerr) in Gir After a drought in Gujarat, India. Biological Conservation 68, 149154.

Kienast, F., Flühler, H., Schweingruber, F.H., 1981. Jahrringanalysen an Föhren (Pinus sylvestris L.) aus immissionsgefährdeten Bestäden des Mittelwallis (Saxon, Schweiz). Waldschäen im Walliser Rhonetal (Schweiz). Mitteilungen Eidg. Anstalt für das forstliche Versuchswesen 57, 415-432.

Kinnaird, M.F., O’Brien, T.G., 1998. Ecological effects of wildfire on lowland rainforest in Sumatra. Conservation Biology 12, 954-956.

Kobelkov, M., 2008. National program on monitoring of large-area decline of boreal and temperate forests and minimization of its consequences with purpose of integration with the international plans of actions in connection with climate change. Oral presentation at: International Conference "Adaptation of Forests and Forest Management to Changing Climate with Emphasis on Forest Health: A Review of Science, Policies, and Practices", FAO/IUFRO, Umea ${ }^{\circ}$, Sweden, 25-28 August 2008.

Kloeppel, B.D., Clinton, B.D., Vose, J.M., Cooper, A.R., 2003. Drought impacts on tree growth and mortality of southern appalachian forests (pp. 43-55). In: Greenland, D., Goodin, D.G., Smith, R.C. (Eds.), Climate Variability and Ecosystem Response at LongTerm Ecological Research Sites. Oxford, Univ. Press, NY, p. 459 pp.

Klos, R.J., Wang, G.G., Bauerle, W.L., Rieck, J.R., 2009. Drought impact on forest growth and mortality in the southeast USA: an analysis using Forest Health and Monitoring data. Ecological Applications 19, 699-708. 
Körner, C., Sarris, D., Christodoulakis, D., 2005. Longterm increase in climatic dryness in the EastMediterranean as evidenced for the island of Samos. Regional Environmental Change Journal 5, 27-36.

Krotov, N.S., 2007. On problems of spruce forest mortality in the Arkhangelsk Region. In: Dying Spruce Forests of Arkhangelsk Region. Problems and Means of their Solution, Department of Forest Complex of Arkhangelsk Region, Arkhangelsk, Russian Federation, pp. 6-11.

Kurz, W.A., Dymond, C.C., Stinson, G., Rampley, G.J., Neilson, E.T., Carroll, A.L., Ebata, T., Safranyik, L., 2008a. Mountain pine beetle and forest carbon feedback to climate change. Nature 452, 987-990.

Kurz, W.A., Stinson, G., Rampley, G.J., Dymond, C.C., Neilson, E.T., 2008b. Risk of natural disturbances makes future contribution of Canada's forests to the global carbon cycle highly uncertain. Proceedings of the National Academy of Sciences of the United States of America 105, 1551-1555 doi:10.1073/pnas.0708133105.

Landmann, G., Dreyer, E. (Eds.), 2006. Impacts of drought and heat on forest. Synthesis of available knowledge, with emphasis on the 2003 event in Europe. Annals of Forest Science 3 (6) 567-652.

Law, J.R., Gott, J.D., 1987. Oak mortality in the Missouri Ozarks. In: Hay, R.L., et, al. (Eds.), Proceedings of the Sixth Central Hardwood Forest Conference, The University of Tennessee, Knoxville, TN, pp. 427-436.

Laurance, W.F., Williamson, G.B., Delamônica, P., Oliveira, A., Lovejoy, T.E., Gascon, C., Pohl, L., 2001. Effects of a strong drought on Amazonian forest fragments and edges. Journal of Tropical Ecology 17, 771-785.

Lawrence, R., Moltzan, B., Moser, K., 2002. Oak decline and the future of Missouri's forests. Missouri Conservationist 63, 11-18.

Leigh, E.G.J., Windsor, D.M., Rand, A.S., Foster, R.B., 1990. The impact of the El Niño drought of 1982-83 on a Panamanian semideciduous forest. In: Glynn, P.W. (Ed.), Global Ecological Consequences of the 1982-83 El Nino-Southern Oscillation. Elsevier, Amsterdam, pp. 473-486.

Leighton, M., Wirawan, N., 1986. Catastrophic drought and fire in Borneo tropical rain forest associated with the 1982-1983 El Nino southern oscillation event. In: Prance, G.T. (Ed.), Tropical Rain Forests and the World Atmosphere. Westview Press, Boulder, CO, USA, pp. 75-102.

Lenton, T.M., Held, H., Kriegler, E., Hall, J.W., Lucht, W., Rahmstorf, W., Schellnhuber, H.J., 2008. Tipping elements in the Earth's climate system. Proceedings of the National Academy of Sciences of the United States of America 105, 1786-1793.

Lewis, S.L., 2006. Tropical forests and the changing earth system. Philosophical Transactions of the Royal Society B-Biological Sciences 361, 195-210 doi:10.1098/rstb.2005.1711.
Li, L.S., 2003. Pine shoot beetle. In: Zhang, X., Luo, Y. (Eds.), Major Forest Disease and Insect Pests in China. Beijing Forestry Publishing House, Beijing, China, pp. 217- 226.

Liang, E.Y., Shao, X.M., Kong, Z.C., Lin, J.X., 2003. The extreme drought in the 1920s and its effect on tree growth deduced from tree ring analysis: a case study in North China. Annals of Forest Science 60 (2), 145152 .

Lim, J.H., Chun, J.H., Woo, S.Y., Kim, Y.K., 2008. Increased declines of Korean fir forest caused by climate change in Mountain Halla, Korea. In: Oral Presentation At: International Conference "Adaptation of Forests and Forest Management to Changing Climate with Emphasis on Forest Health: A Review of Science, Policies, and Practices", Umea ${ }^{\circ}$, Sweden, FAO/IUFRO, 25-28 August 2008.

Lingenfelder, M., Newbery, D.M., 2009. On the detection of dynamic responses in a drought-perturbed tropical rainforest in Borneo. Plant Ecology 201, 267 290.

Lloret, F., Siscart, D., 1995. Los efector demograficos de la sequia en poblaciones de encina. Cuadernos de la Sociedad Espanola de Ciencias Forestales 2, 77-81.

Lloret, F., Siscart, D., Dalmases, C., 2004. Canopy recovery after drought dieback in holm-oak Mediterranean forests of Catalonia (NE Spain). Global Change Biology 10, 2092-2099.

Lloyd, A.H., Bunn, A.G., 2007. Responses of the circumpolar boreal forest to $20^{\text {th }}$ century climate variability. Environmental Research Letters 2, 045013, doi:10:1088/1748-9326/2/4/045013.

Loehle, C., LeBlanc, D., 1996. Model-based assessments of climate change effects on forests: a critical review. Ecological Modelling 90, 1-31.

Logan, J., Regniere, J., Powell, J.A., 2003. Assessing the impacts of global warming on forest pest dynamics. Frontiers in Ecology and the Environment 1, 130-137.

Lu, J., Deser, C., Reichler, T., 2009. Cause of the widening of the tropical belt since 1958. Geophysical Research Letters 36, L03803.

Lucht, W., Schaphoff, S., Erbrecht, T., Heyder, U., Cramer, W., 2006. Terrestrial vegetation redistribution and carbon balance under climate change. Carbon Balance and Management 1, 6 doi:10.1186/1750-06801-6.

Lwanga, J.S., 2003. Localized tree mortality following the drought of 1999 at Ngogo, Kibale National Park, Uganda. African Journal of Ecology 41, 194-196.

MacGregor, S.D., O’Connor, T.G., 2002. Patch dieback of Colophospermum mopane in a dysfunctional semi-arid African savanna. Austral Ecology 27, 385-395.

Macomber, S.A., Woodcock, C.E., 1994. Mapping and monitoring conifer mortality using remote sensing in the Lake Tahoe Basin. Remote Sensing of Environment 50, 255-266. 
Maherali, H., Pockman, W.T., Jackson, R.B., 2004. Adaptive variation in the vulnerability of woody plants to xylem cavitation. Ecology 85, 2184-2199.

Man'ko, U.I., Gladkova, G.A., 2001. Spruce Mortality in the Light of the Global Decline of Dark Coniferous Forests. Russian Academy of Sciences, Far East Branch, Vladivostok, 228 pp.

Manion, P.D., 1991. Tree Disease Concepts, 2nd ed. Prentice-Hall Inc., Upper Saddle River, NJ, 416 pp.

Manion, P.D., Lachance, D., 1992. Forest Decline Concepts. APS Press, St. Paul, MN, 249 pp.

Markalas, S., 1992. Site and stand factors related to mortality-rate in a fir forest after a combined incidence of drought and insect attack. Forest Ecology and Management 47, 367-374.

Martinez-Vilalta, J., Pin ol, J., 2002. Drought-induced mortality and hydraulic architecture in pine populations of the NE Iberian Peninsula. Forest Ecology and Management 161, 247-256.

Mattson, W.J., Haack, R.A., 1987. The role of drought in outbreaks of plant-eating insects. BioScience 37 , 110-118.

McDowell, N., Pockman, W.T., Allen, C.D., Breshears, D.D., Cobb, N., Kolb, T., Sperry, J., West, A., Williams, D., Yepez, E.A., 2008. Mechanisms of plant survival and mortality during drought: why do some plants survive while others succumb to drought? Tansley review. New Phytologist 178, 719-739.

McDowell, N., Allen, C.D., Marshall, L., 2009. Growth, carbon isotope discrimination, and climateinduced mortality across a Pinus ponderosa elevation transect. Global Change Biology, doi:10.1111/j.13652486.2009.01994.x.

Miao, S.L., Zou, C.B., Breshears, D.D., 2009. Vegetation responses to extreme hydrological events: sequence matters. American Naturalist 173, 113-118.

Millar, C.I., Westfall, R.D., Delany, D.L., 2007a. Response of high-elevation limber pine (Pinus flexilis) to multiyear droughts and 20th-century warming, Sierra Nevada, California, USA. Canadian Journal of Forest Research-Revue Canadienne De Recherche Forestière 37, 2508-2520.

Millar, C.I., Stephenson, N.L., Stephens, S.L., 2007 b. Climate change and forests of the future: managing in the face of uncertainty. Ecological Applications 17, 2145-2151.

Millennium Ecosystem Assessment, 2005. Ecosystems and Human Well-being: Synthesis. Island Press, Washington, DC, 137 pp.

Millers, I., Shriner, D.S., Rizzo, D. 1989. History of hardwood decline in the Eastern United States. Gen. Tech. Rep. NE-126. U.S. Department of Agriculture, Forest Service, Northeastern Forest Experiment Station, Broomall, PA, pp. 75.

Minerbi, S., 1993. Wie gesund sind unsere Wälder? 10. Bericht über den Zustand der Wälder in Südtirol. Agrar- und Forstbericht, Autonome Provinz Bozen, Assessorate für Land-und Forstwirtschaft, pp 40.
Minnesota Department of Natural Resources. 2007. Federal conditions report 2007. 24 pp. http://fhm.fs.fed.us/fhh/fhh_07/mn_fhh_07.pdf

Mueller, R.C., Scudder, C.M., Porter, M.E., Trotter, R.T., Gehring, C.A., Whitham, T.G., 2005. Differential tree mortality in response to severe drought: evidence for long-term vegetation shifts. Journal of Ecology 93, 1085-1093.

Mueller-Dombois, D., 1986. Perspectives for an etiology of stand-level dieback. Annual Review of Ecology and Systematics 17, 221-243.

Mueller-Dombois, D., 1988. Towards a unifying theory for stand-level dieback. GeoJournal 17, 249-251.

Nageleisen, L.-M., Hartmann, G., Landmann, G., 1991. Dépérissements d'essences feuillues en Europe Occidentale: cas particulier des chênes rouvre et pédonculé Revue Forestière Française $\mathrm{n}^{\circ} 8$ hors série, vol. 2, pp. 301-306.

Nageleisen, L.-M., 1994. Dépérissement actuel des chênes. Revue Forestière Française 46 (5), 504-511.

Nakagawa, M., Tanaka, K., Nakashizuka, T., Ohkubo, T., Kato, T., Maeda, T., Sato, K., Miguchi, H., Nagamasu, H., Ogino, K., Teo, S., Hamid, A.A., Seng, L.H., 2000. Impact of severe drought associated with the 1997-1998 El Nino in a tropical forest in Sarawak. Journal of Tropical Ecology 16, 355-367.

Navarro-Cerrillo, R., Varo, M.A., Lanjeri, S., Herna'ndez-Clemente, R., 2007. Cartografía de defoliación en los pinares de pino silvestre (Pinus sylvestris L.) y pino salgareño (Pinus nigra Arnold.) en la Sierra de los Filabres. Ecosistemas. 2007/3. url: http://www.revistaecosistemas.net/articulo.asp? Id=495.

Negron, J.F., McMillin, J.D., Anhold, J.A., Coulson, D., 2009. Bark beetle-caused mortality in a droughtaffected ponderosa pine landscape in Arizona, USA. Forest Ecology and Management 257, 1353-1362.

Nepstad, D.C., Tohver, I.M., Ray, D., Moutinho, P., Cardinot, G., 2007. Mortality of large trees and lianas following experimental drought in an Amazon forest. Ecology 88, 2259-2269.

Nepstad, D.C., Stickler, C.M., Soares-Filho, B., Merry, F., 2008. Interactions among Amazon land use, forests and climate: prospects for a near-term forest tipping point. Philosophical Transactions of the Royal Society B-Biological Sciences 363, 1737-1746.

Newbery, D.M., Lingenfelder, M., 2009. Plurality of tree species responses to drought perturbation in Bornean tropical rain forest. Plant Ecology 201, 147167.

Nishimua, T.B., Suzuki, E., Kohyama, T., Tsuyuzaki, S., 2007. Mortality and growth of trees in peat-swamp and heath forests in Central Kalimantan after severe drought. Plant Ecology 188, 165-177.

O'Connor, T.G., 1999. Impact of sustained drought on a semiarid Colophospermum mopane savanna. African Journal of Forage Science 15, 83-91. 
Oak, S.W., Steinman, J.R., Starkey, D.A., Yocey, E.K., 2004. Assessing oak decline incidence and distribution in the southern U.S. using forest inventory and analysis data. In: Spetich, M.A. (Ed.), Upland Oak Ecology Symposium: History, Current Conditions, and Sustainability, Gen. Tech. Rep. SRS-73, USDA Forest Service, Southern Research Station, Asheville, NC, pp. 236- 242

Oberhuber, W., 2001. The role of climate in the mortality of Scots pine (Pinus sylvestris L.) exposed to soil dryness. Dendrochronologia 19, 45-55.

Ogaya, R., Penuelas, J., 2007. Tree growth, mortality, and above-ground biomass accumulation in a holm oak forest under a five-year experimental field drought. Plant Ecology 189, 291-299.

Ogle, K., Whitham, T.G., Cobb, N.S., 2000. Tree-ring variation in pinyon predicts likelihood of death following severe drought. Ecology 81, 3237-3243.

Olano, J.M., Palmer, M.W., 2003. Stand dynamics of an Appalachian old-growth forest during a severe drought episode. Forest Ecology and Management 174, 139-148.

Ogibin B.N., Demidova, N.A. Successional dynamics of old-growth spruce forests in the watersheds of the rivers Northern Dvina-Pinega in the Arkhangelsk Region. In: Kauhanen, H., Neshataev, V., Vuopio, M. (Eds.), Northern Coniferous Forests - From Research to Ecologically Responsible Forestry. Finnish Forest Research Institute, Helsinki, in press.

Ollinger, S.V., Goodale, C.L., Hayhoe, K., Jenkins, J.P., 2008. Effects of predicted changes in climate and atmospheric composition on ecosystem processes in northeastern U.S. forests. Mitigation and Adaptation Strategies for Global Change 13, 467-485.

Parmesan, C., 2006. Ecological and evolutionary responses to recent climate change. Annual Review of Ecology, Evolution, and Systematics 37, 637-669.

Payette, S., Fortin, M.J., Morneau, C., 1996. The recent sugar maple decline in southern Quebec: probable causes deduced from tree rings. Canadian Journal of Forest Research-Revue Canadienne De Recherche Forestière 26, 1069-

1078.

Pedersen, B.S., 1998. The role of stress in the mortality of Midwestern oaks as indicated by growth prior to death. Ecology 79, 79-93.

Pedersen, B.S., 1999. The mortality of midwestern overstory oaks as a bioindicator of environmental stress. Ecological Applications 9, 1017-1027.

Peñuelas, J., Lloret, F., Montoya, R., 2001. Severe drought effects on mediterranean woody flora in Spain. Forest Science 47, 214-218.

Petercord, R., 2008. Zukünftige gefährdung der Rotbuche durch rinden- und holzbrütende Käfer in Baden-Wüttemberg. Mitteilungen der Deutsche Gesellschaft für Allgemeine und Angewandte Entomologie 16, 247-250.
Phillips, O.L., Lewis, S.L., Baker, T.R., Chao, K.-J., Higuchi, N., 2008. The changing Amazon forest. Philosophical Transactions of the Royal Society BBiological Sciences 363, 1819-1827.

Phillips, O.L., Aragão, L.E.O.C., Lewis, S.L., Fisher, J.B., Lloyd, J., López-González, G., Malhi, Y., Monteagudo, A., Peacock, J., Quesada, C.A., van der Heijden, G., Almeida, S., Amaral, I., Arroyo, L., Aymard, G., Baker, T.R., Ba' nki, O., Blanc, L., Bonal, D., Brando, P., Chave, J., Alves de Oliveira, A' .C., Dávila Cardozo, N., Czimczik, C.I., Feldpausch, T.R., Freitas, M.A., Gloor, E., Higuchi, N., Jiménez, E., Lloyd, G., Meir, P., Mendoza, C., Morel, A., Neill, D.A., Nepstad, D., Patiño, S., Peñuela, M.C., Prieto, A., Ramírez, F., Schwarz, M., Silva, J., Silveira, M., Sota Thomas, A., ter Steege, H., Stropp, J., Vásquez, R., Zelazowski, P., Alvarez Dávila, E., Andelman, S., Andrade, A., Chao, K., Erwin, T., Di Fiore, A., Honorio, C., Keeling, E., Killeen, H., Laurance, T.J., Peña Cruz, W.F., Pitman, A., Núñez Vargas, N.C.A., Ramírez-Angulo, P., Rudas, H., Salamão, A., Silva, R., Terborgh, N., Torres- Lezama, J.A., 2009. Drought sensitivity of the Amazon rainforest. Science 323, 1344-1347.

Potts, M.D., 2003. Drought in a Bornean everwet rain forest. Journal of Ecology 91, 467-474.

Poupon, H., 1980. Structure et dynamique de la strate ligneuse d'une steppes Sahélienne au nord du Sénégal. Travaux et documents de l' O.R.S.T.O.M. no. 115, O.R.S.T.O.M., Paris.

Raffa, K.F., Aukema, B.H., Bentz, B.J., Carroll, A.L., Hicke, J.A., Turner, M.G., Romme, W.H., 2008. Crossscale drivers of natural disturbances prone to anthropogenic amplification: the dynamics of bark beetle eruptions. Bioscience 58, 501-517.

Raftoyannis, Y., Spanos, I., Radoglou, K., 2008. The decline of Greek fir (Abies cephalonica Loudon): Relationships with root condition. Plant Biosystems 142, 386-390.

Rennenberg, H., Loreto, F., Polle, A., Brilli, F., Fares, S., Beniwal, R.S., Gessler, A., 2006. Physiological responses of forest trees to heat and drought. Plant Biology 8, 556-571.

Rice, K.J., Matzner, S.L., Byer, W., Brown, J.R., 2004. Patterns of tree dieback in Queensland, Australia: the importance of drought stress and the role of resistance to cavitation. Oecologia 139, 190-198.

Rich, P.M., Breshears, D.D., White, A.B., 2008. Phenology of mixed woody-herbaceous ecosystems following extreme events: net and differential responses. Ecology 89, 342-352.

Richardson, D.M., et al., 2009. Multidimensional evaluation of managed relocation. Proceedings of the National Academy of Sciences of the United States of America 1062 (24), 9721-9724.

Rigling, A., Cherubini, P., 1999. Wieso sterben die Waldföhren im Telwald bei Visp? Schweizerische Zeitschrift für Forstwesen 150, 113-131. 
Rigling, A., Dobbertin, M., Bürgi, M., FeldmeierChriste, E., Gimmi, U., Ginzler, C., Graf, U., Mayer, P., Zweifel, R., Wohlgemuth, T., 2006. Baumartenwechsel in den Walliser Waldföhrenwäldern. In: Wohlgemuth, T. (Red.), Wald und Klimawandel. Forum für Wissen 2006, 71 pp.

Robitaille, L., Allard, G., Bordeleau, M., Dessureault, M., Gagnon, F., Lachance, D., Picher, R., Roberge, M., 1982. Mortalité dans les érablières: tournée du 12, 13 et 14 octobre dans les régions de Québec (Beauce), de l'Estrie et de Trois-Rivières. Gouv. Du Québec, Min. de l'énergie. et des ressources, Dir. de la recherche forestière. Rapport interne $n^{\circ} 8227,33$.

Rolim, S.G., Jesus, R.M., Nascimento, H.E.M., do Couto, H.T.Z., Chambers, J.Q., 2005. Biomass change in an Atlantic tropical moist forest: the ENSO effect in permanent sample plots over a 22-year period. Oecologia 142, 238-246.

Rouault, G., Candau, J.N., Lieutier, F., Nageleisen, L.M., Martin, J.C., Warzee, N., 2006. Effects of drought and heat on forest insect populations in relation to the 2003

drought in Western Europe. Annals of Forest Science 63, 613-624.

Roy, G., Larocque, G.R., Ansseau, C., 2004. Retrospective evaluation of the onset

period of the visual symptoms of dieback in five Appalachian sugar maple stand

types. Forestry Chronicle 80, 375-383.

Ryan, M.G., Phillips, N., Bond, B.J., 2006. The hydraulic limitation hypothesis

revisited. Plant, Cell and Environment 29, 367-381.

Sala, A., Hoch, G., 2009. Height-related growth declines in ponderosa pine are not due to carbon limitation. Plant, Cell and Environment 32, 22-30.

Sarris, D., Christodoulakis, D., Ko“ rner, C., 2007. Recent decline in precipitation and tree growth in the eastern Mediterranean. Global Change Biology 13 (6), 1187- 1200 .

Savage, M., 1997. The role of anthropogenic influences in a mixed-conifer forest mortality episode. Journal of Vegetation Science 8, 95-104.

Schilli, S., Dobbertin, M., Rigling, A., Bucher, H.U., in press. Waldföhrensterben im Churer Rheintal - ein Vergleich zum Wallis. Bündnerwald.

Scholze, M., Knorr, W., Arnell, N.W., Prentice, I., 2006. A climate-change risk analysis for world ecosystems. Proceedings of the National Academy of Sciences of the United States of America 103, 1311613120.

Schutt, P., Cowling, E.B., 1985. Waldsterben, a general decline of forests in central Europe: symptoms, development, and possible causes. Plant Disease 69, $548-558$.
Seager, R., Ting, M., Held, I., Kushnir, Y., Lu, J., Vecchi, G., Huang, H.-P., Harnik, N., Leetmaa, A., Lau, N.-C., Li, C., Velez, J., Naik, N., 2007. Model projections of an imminent transition to a more arid climate in southwestern North America. Science 316, 1181-1184.

Seidel, D.J., Fu, Qiang, Randel, W.J., Reichler, T.J., 2008. Widening of the tropical belt in a changing climate. Nature Geoscience 1, 21-24.

Semerci, A., S,anlı, B.N., S,ahin, O* ., C, elik, O., Balkız, G.B., Ceylan, S., Argun, N., 2008. Examination of tree mortalities in semi-arid central Anatolian region of Turkey during last six-year period (2002-2007). Poster presentation at: International Conference "Adaptation of Forests and Forest Management to Changing Climate with Emphasis on Forest Health: A Review of Science, Policies, and Practices', Umea , Sweden, FAO/IUFRO, 25-28 August 2008.

Seppala, R., Buck, A., Katila, P. (eds.), 2009. Adaptation of Forests and People to Climate ChangeA Global Assessment Report. IUFRO World Series Vol. 22. International Union of Forest Research Organizations, Helsinki, 224 pp.

Shaw, J.D., Steed, B.E., DeBlander, L.T., 2005. Forest Inventory and Analysis (FIA) annual inventory answers the question: What is happening to pinyonjuniper woodlands? Journal of Forestry 103, 280-285.

Shtrakhov, 2008. Forest health and protection in Russia. In: Oral Presentation At: International Conference "Adaptation of Forests and Forest Management to Changing Climate with Emphasis on Forest Health: A Review of Science, Policies, and Practices", Umea ${ }^{\circ}$, Sweden, FAO/IUFRO, 25-28 August 2008.

Siwecki, R., Ufnalksi, K., 1998. Review of oak stand decline with special reference to the role of drought in Poland. European Journal of Forest Pathology 28, 99112.

Skelly, J.M., Innes, J.L., 1994. Waldsterben in the forests of Central Europe and Eastern North America fantasy or reality? Plant Disease 78, 1021-1032.

Slik, J.W.F., 2004. El Nino droughts and their effects on tree species composition and diversity in tropical rain forests. Oecologia 141, 114-120.

Soja, A.J., Tchebakova, N.M., French, N.H.F., Flannigan, M.D., Shugart, H.H., Stocks, B.J., Sukhinin, A.I., Varfenova, E.I., Chapin, F.S., Stackhouse Jr., P.W., 2007. Climate-induced boreal forest change: predictions versus current observations. Global and Planetary Change 56 (3-4), 274-296.

Solberg, S., 2004. Summer drought: a driver for crown condition and mortality of Norway spruce in Norway. Forest Pathology 34, 93-107.

Starkey, D.A., Oak, S.W., Ryan, G.W., Tainter, F.H., Redmond, C., Brown, H.D., 1989. Evaluation of oak decline areas in the south. Protection Report R8-PR 17, US Forest Service, 36 pp. 
Starkey, D.A., Oak, S.W., 1989. Site factors and stand conditions associated with oak decline in southern upland hardwood forests. In: Rink, G., Budelsky, C.A. (Eds.), Proceedings of the Seventh Central Hardwood Conference, Carbondale, IL, 5-8 March 1989. Gen. Tech. Rep. NC-132. USDA Forest Service, North Central Forest Experiment Station, St. Paul, MN, pp. 95-102.

Starkey, D.A., Oliveria, F., Mangini, A., Mielke, M., 2004. Oak decline and red oak borer in the interior highlands of Arkansas and Missouri: natural phenomena, severe occurrences. In: Spetich, M.A. (Ed.), Upland Oak Ecology Symposium: History, Current Conditions, and Sustainability, Gen. Tech. Rep. SRS-73, USDA Forest Service, Southern Research Station, Asheville, NC, pp. 217-222.

Sterl, A., et al., 2008. When can we expect extremely high surface temperatures? Geophysical Research Letters 35, L14703 doi:10.1029/2008GL034071.

Stringer, J.W., Kimmer, T.W., Overstreet, J.C., Dunn, J.P., 1989. Oak mortality in eastern Kentucky. Southern Journal of Applied Forestry 13, 86-91.

Suarez, M.L., Kitzberger, T., 2008. Recruitment patterns following a severe drought: long-term compositional shifts in Patagonian forests. Canadian Journal of Forest Research 38, 3002-3010.

Suarez, M.L., Ghermandi, L., Kitzberger, T., 2004. Factors predisposing episodic drought-induced tree mortality in Nothofagus: site, climatic sensitivity and growth trends. Journal of Ecology 92, 954-966.

Swaty, R.L., Deckert, R.J., Whitham, T.G., Gehring, C.A., 2004. Ectomycorrhizal abundance and community composition shifts with drought: predictions from tree rings. Ecology 85, 1072-1084.

Swetnam, T.W., Betancourt, J.L., 1998. Mesoscale disturbance and ecological response to decadal climatic variability in the American southwest. Journal of Climate 3128-3147.

Tafangenyasha, C., 1997. Tree loss in the Gonarezhou National Park (Zimbabwe) between 1970 and 1983. Journal of Environmental Management 49, 355-366.

Tafangenyasha, C., 1998. Phenology and mortality of woody plants during and after a severe drought in southeastern Zimbabwe. Transactions of Zimbabwe Scientific Association 72, 1-6.

Tafangenyasha, C., 2001. Decline of the mountain acacia, Brachystegia glaucescens in Gonarezhou National Park, southeast Zimbabwe. Journal of Environmental Management 63, 37-50.

Tainter, F.H., Williams, T.M., Cody, J.B., 1983. Drought as a cause of oak decline and death on the South Carolina coast. Plant Disease 67, 195-197.

Thabeet, A., Vennetier, M., Gadbin-Henry, C., Denelle, N., Roux, M., Caraglio, Y., Vila, B., 2009. Response of Pinus sylvestris L. to recent climate change in the French Mediterranean region. Trees, Structure and Functions 23 (4), 843-853.
Thuiller, W., Albert, C., Araujo, M.B., Berry, P.M., Cabeza, M., Guisan, A., Hickler, T., Midgley, G.F., Paterson, J., Schurr, F.M., Sykes, M.T., Zimmermann, N.E., 2008. Predicting global change impacts on plant species' distributions: future challenges. Perspectives in Plant Ecology, Evolution and Systematics 9, 137152.

Touchan, R., Anchukaitis, K.J., Meko, D.M., Attalah, S., Baisan, C., Aloui, A., 2008. Long term context for recent drought in northwestern Africa. Geophysical Research Letters 35, L13705.

Trotter, R.T.I., 2004. Linking Climate Change and Community Dynamics: Pinyon Pine Stability and Sensitivity in a Heterogeneous Landscape. Northern Arizona University.

Tsopelas, P., Angelopoulos, A., Economou, A., Soulioti, N., 2004. Mistletoe (Viscum album) in the fir forest of Mount Parnis, Greece. Forest Ecology and Management 202, 59-65.

Tsvetkov, V.F., Tsvetkov, V.I., 2007. The problem of spruce forests-mortality in the Arkhangelsk Region. In: Dying Spruce Forests of Arkhangelsk Region. Problems and Means of their Solution, Department of Forest Complex of Arkhangelsk Region, Arkhangelsk, Russian Federation, pp. 20-30.

van Mantgem, P.J., Stephenson, N.L., 2007. Apparent climatically induced increase of tree mortality rates in a temperate forest. Ecology Letters 10, 909-916.

van Mantgem, P.J., Stephenson, N.L., Byrne, J.C., Daniels, L.D., Franklin, J.F., Fule' , P.Z., Harmon, M.E., Larson, A.J., Smith, J.M., Taylor, A.H., Veblen, T.T., 2009. Widespread increase of tree mortality rates in the western United States. Science 323, 521-524.

van Nieuwstadt, M.G.L., Sheil, D., 2005. Drought, fire and tree survival in a Borneo rain forest, East Kalimantan, Indonesia. Journal of Ecology 93, 191201.

Vennetier, M., Vila, B., Liang, E.Y., Guibal, F., Thabeet, A., Gadbin-Henry, C., 2007. Impact of climate change on pine forest productivity and on the shift of a bioclimatic limit in a Mediterranean area. Options Méditerranéennes, Série A, n8 75, CIHEAM/IAMB, Bari, Italy, pp. 189-197.

Vennetier, M., Cecillon, L., Guénon, R., Schaffhauser, A., Vergnoux, A., Boichard, J.-L., Bottéro, J.-Y., Brun, J.-J., Carrara, M., Cassagne, N., Chandioux, O., ClaysJosserand, A., Commeaux, C., Curt, T., Czarnes, S., De Danieli, S., Degrange, V., Di Rocco, R., Domeizel, M., Doumenq, P., Doussan, C., Estève, R., Faivre, N., Favier, G., Gaudu, J.-C., Gros, R., Guiliano, M., Guillaumaud, N., Hoepffner, M., Juvy, B., Le Roux, X., Lebarriller, S., Malleret, L., Martin, W., Mas, C., Masion, A., Massiani, C., Mermin, E., Mille, G., Morge, D., Pignot, V., Poly, F., Renard, D., Ripert, C., Ruy, S., Tardif, P., Tatoni, T., Théraulaz, F., Vassalo, L., Asia, L., 2008. Etude de l'impact d'incendies de forêt répétés sur la biodiversité et sur les sols: recherche d'indicateurs. Rapport final. Cemagref, 
Ministère de l'Agriculture et de la pêche, Union Européenne, Aix en Provence, 236 p.

Vertui, F., Tagliaferro, F., 1998. Scots pine (Pinus sylvestris L.) die-back by unknown causes in the Aosta Valley, Italy. Chemosphere 36, 1061-1065.

Viljoen, A.J., 1995. The influence of the 1991/92 drought on the woody vegetation of the Kruger National Park. Koedoe 32, 85-97.

Villalba, R., Veblen, T.T., 1998. Influences of largescale climatic variability on episodic tree mortality in northern Patagonia. Ecology 79, 2624-2640.

Voelker, S.L., Muzika, R., Guyette, R.P., 2008. Individual tree and stand level influences on the growth, vigor, and decline of Red Oaks in the Ozarks. Forest Science 54, 8-20.

Walther, G.-R., Berger, S., Sykes, M.T., 2005. An ecological "footprint" of climate change. Proceedings of the Royal Society B 272, 1427-1432.

Wang, H.B., Zhang, Z., Kong, X.B., Lui, S.C., Shen, Z.R., 2007. Preliminary deduction of potential distribution and alternative hosts of invasive pest, Dendroctonus valens (Coleoptera: Scolytidae). Scientia Silvae Sinicae 143, 71-76.

Waring, R.H., 1987. Characteristics of trees predisposed to die. Bioscience 37, 569- 577.

Wermelinger, B., Seifert, M., 1999. Temperaturedependent reproduction of the spruce bark beetle Ips typographus, and analysis of the potential population growth. Ecological Entomology 24, 103-110.

Wermelinger, B., Rigling, A., Schneider, M., Dobbertin, M., 2008. Assessing the role of bark- and wood-boring insects in the decline of Scots pine (Pinus sylvestris) in the Swiss Rhone valley. Ecological Entomology 33, 239-249.
Werner, W.L., 1988. Canopy dieback in the upper montane rain forests of Sri Lanka. GeoJournal 17, 245248.

Williamson, G.B., Laurance, W.F., Oliveira, A.A., Delamonica, P., Gascon, C., Lovejoy, T.E., Pohl, L., 2000. Amazonian tree mortality during the $1997 \mathrm{El}$ Nino drought. Conservation Biology 14, 1538-1542.

Woo, S.-Y., Lim, J.H., Je, S.M., Lee, D.K., Kwon, M.J., Ryang, S., 2007. Decline in Mt. Halla-A Linkage with Physiological Changes Caused by Climate Change.In: Fourth USDA Greenhouse Gas Conference, Baltimore, MD, 6 February 2007.

Woods, P., 1989. Effects of logging, drought, and fire on structure and composition of tropical forests in Sabah, Malaysia. Biotropica 21, 290-298.

Worrall, J.J., Egeland, L., Eager, T., Mask, R.A., Johnson, E.W., Kemp, P.A., Shepperd, W.D., 2008. Rapid mortality of Populus tremuloides in southwestern Colorado, USA. Forest Ecology and Management 255, 686-696.

Würth, M.K.R., Peláez-Riedl, S., Wright, S.J., Körner, C., 2005. Non-structural carbohydrate pools in a tropical forest. Oecologia 143, 11-24.

Zweifel, R., Zeugin, F., 2008. Ultrasonic acoustic emissions in drought-stressed trees - more than signals from cavitation? New Phytologist 179, 1070-1079.

Zweifel, R., Rigling, A., Dobbertin, M., 2009. Speciesspecific stomatal response of trees to microclimate - a link to vegetation dynamics? Journal of Vegetable Science 20, 442-454. 